\title{
A Review of Storage Battery System Cost Estimates
}

\author{
D. R. Brown \\ J. A. Russell
}

April 1986

Prepared for the U.S. Department of Energy under Contract DE-AC06-76RLO 1830

Pacific Northwest Laboratory Operated for the U.S. Department of Energy by Battelle Memorial Institute 


\title{
DISCLAIMER
}

This report was prepared as an account of work sponsored by an agency of the United States Government. Neither the United States Government nor any agency thereof, nor any of their employees, makes any warranty, express or implied, or assumes any legal liability or responsibility for the accuracy, completeness, or usefulness of any information, apparatus, product, or process disclosed, or represents that its use would not infringe privately owned rights. Reference herein to any specific commercial product, process, or service by trade name, trademark, manufacturer, or otherwise, does not necessarily constitute or imply its endorsement, recommendation, or favoring by the United States Government or any agency thereof. The views and opinions of authors expressed herein do not necessarily state or reflect those of the United States Government or any agency thereof.

\author{
PACIFIC NORTHWEST LABORATORY \\ operated by \\ BATTELLE \\ for the \\ UNITED STATES DEPARTMENT OF ENERGY \\ under Contract DE-AC06-76RLO 1830
}

\begin{tabular}{|c|c|}
\hline \multicolumn{2}{|c|}{ Printed in the United States of America } \\
\hline \multicolumn{2}{|c|}{$\begin{array}{c}\text { Available from } \\
\text { Avatice }\end{array}$} \\
\hline \multirow{4}{*}{\multicolumn{2}{|c|}{$\begin{array}{c}\text { National Technical Information Service } \\
\text { United States Department of Commerce } \\
5285 \text { Port Royal Road } \\
\text { Springfield, Virginia } 22161\end{array}$}} \\
\hline & \\
\hline & \\
\hline & \\
\hline \multirow{2}{*}{\multicolumn{2}{|c|}{$\begin{array}{l}\text { NTIS Price Codes } \\
\text { Microfiche A01 }\end{array}$}} \\
\hline & \\
\hline \multicolumn{2}{|c|}{ Printed Copy } \\
\hline & Price \\
\hline Pages & \\
\hline $001-025$ & $\mathrm{~A} 02$ \\
\hline $026-050$ & $\mathrm{A03}$ \\
\hline $051-075$ & A04 \\
\hline $076-100$ & A05 \\
\hline $101-125$ & $A 06$ \\
\hline $126-150$ & $\mathrm{~A} 07$ \\
\hline $151-175$ & $A 0 B$ \\
\hline $176-200$ & $A 09$ \\
\hline $201-225$ & A010 \\
\hline $226-250$ & A011 \\
\hline $251-275$ & A012 \\
\hline $276-300$ & A013 \\
\hline
\end{tabular}




\section{A REVIEW OF STORAGE BATTERY SYSTEM COST ESTIMATES}

D. R. Brown

J. A. Russell

April 1986

Prepared for the U.S. Department of Energy under Contract DE-ACO6-76RLO 1830

Pacific Northwest Lahoratory Richland, Washington 99352 


\title{
• \\ ,
}

4

\author{
(
}


The purpose of the work described in this report was to identify the cur rent status of battery system cost analyses and make recommendations for future work in this area. Cost analyses for zinc bromine, sodium sulfur, and lead acid batteries were reviewed. Zinc bromine and sodium sulfur batteries were selected because of their advanced design nature and the high level of interest in these two technologies. Lead acid batteries were included to establish a baseline representative of a more mature technology.

The most recent and thorough cost analyses of zinc bromine, sodium sulfur and lead acid battery systems were sought for the review. Zinc hromine and sodium sulfur battery developers were contacted to ensure that the latest and/or most detailed analyses were being considered. Current manufacturers of lead acid batteries were not contacted since interest was primarily oriented toward lead acid battery cost analyses that were completed during the earlier development stages of that technology. The lead acid battery cost analyses served as a bench mark for comparison with zinc bromine and sodium sulfur battery cost analyses. The time frame of the analysis process limited PNL's review to publications available by the end of 1984 .

An essential part of the review process was the development of a list of cost characterizing information relevant to battery systems. The list defines the type of information and level of detail that should be avaifable to fully and adequately evaluate the costs of a battery system. Following a standard set of estimating guidelines would benefit the cost analysis process by providing more consistency between estimates, more complete estimates, more accurate estimates, and better reproducibility by independent parties. All of these factors would give greater credence to the estimated costs and enhance their usefulness to the R\&D planning process.

The list of cost characterizing information is headed by six categories: system description summary, design specifications, performance specifications, manufacturing cost, installed system cost, and life-cycle cost. System description and design/performance specifications define the system being 
costed and serve to identify cost differences among systems stemming from differences in system boundary, design type, and performance characteristics. Cost estimating ground rules and assumptions are defined within each of the cost categories. Each category addresses the costing premises and emphasized the inclusion of all cost components pertinent to manufacturing, installed system, and life-cycle costs, respectively.

Each of the battery system cost analyses reviewed was evaluated with regard to the system completeness and level of detail assocjated with the cost characterizing information described above. The emphasis of the evaluation was oriented toward determining whether the information presented would allow an independent reconstruction of the estimate and/or reconciliation of estimates from different sources. No attempt was made in this study to validate any single estimate or reconcile two or more estimates to common assumptions.

In general, cost analyses for mature lead acid batteries have been more numerous, more complete, and have greater detail than for either zinc bromine or sodium sulfur batteries. Several cost analyses completed for lead acid batteries could, with minor modifications, serve as examples of expected levels of detail and completeness for other batteries. The quality of the economic analyses combined with the greater commercial experience has created less uncertainty in estimated costs for lead acid battery systems.

The lack of maturity in zinc hromine and sodium sulfur battery cost analyses, when compared to lead acid batteries, can be partiy attributed to the differences in design maturity. The level of design detail available provides an upper limit to the level of cost detail possible. Still, improvements could be made even at the current level of design maturity. Problems currently facing zinc bromine and sodium sulfur battery cost analyses are briefly discussed below:

- Cost information is fragmented. No single report addresses each of the six major categories of cost characterizing information. Rapidly changing designs make it difficult to trace costs presented in one report to design information presented in another report. 
- Completeness of estimates varies significantly. Incomplete estimates inevitably lead to underestimated costs. Differences in completeness also makes direct comparison of cost estimates impossible.

- May estimates lack supporting details. Lack of detail makes an independent reproduction of the estimate impossible, thus lowering credibility. For example, descriptions of manufacturing operations, floor space requirements, and equipment were often limited, if they existed at al1.

- Very few installed system or life-cycle cost estimates. Estimates of installed system and life-cycle costs were limited to three sources for zinc bromine batteries and two sources for sodium sulfur batteries.

The following observations apply to all battery systems. Converter costs were found to vary widely with assumptions made regarding power level, design, and production volume. Converters for large battery systems are currently in their own developmental phase and suffer from cost uncertainty that is comparable with that for the batteries themselves. Finally, it is important to remember that the technical feasibility, the probability a battery will work as advertised, may be significantly different for two batteries that are estimated to have similar installed-system and life-cycle costs. Two systems must provide a similar service in order for cost comparisons to be meaningfu?.

In view of the observations summarized above, the following recommendations are offered as a means to improve battery cost analyses:

1. Develop standard guidelines which establish the systern components to be included, the appropriate level of detail in description, and ground rules and assumptions for estimating manufacturing, installation, and life-cycle costs. The implementation of guidelines would serve to standardize the economic analysis procedure and focus on cost differences attributable to differences in hattery type or design. 
2. Spend more effort characterizing installed system and life-cycle costs. Balance-of-plant, battery replacement, and 08M costs are just as important as manufacturing costs to the total battery system cost. Additional balance-of-plant and life-cycle cost studies are needed to develop a balanced set of cost characterizing information.

3. Complete cost analyses in more detail and more frequently. More frequent cost analyses will minimize the problem of cost analyses becoming outdated by changes in technology.

Each of the recommendations cited above represents a part of an overall plan to enhance the state of battery cost analysis. The availability of quality cost data is seen as a first step in this plan. Consistent cost analyses completed for the entire battery system will lay the groundwork for the development of cost goals and R\&D plans, market assessments, and cost/performance tradeoffs. 


\section{CONTENTS}

SUMMARY

ii

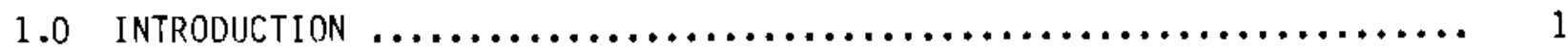

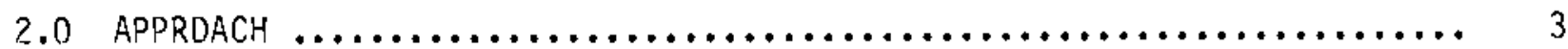

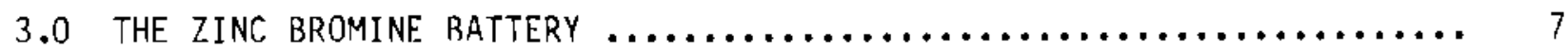

3.1 BATTERY DESCRIPTION $\ldots \ldots \ldots \ldots \ldots \ldots \ldots \ldots \ldots \ldots \ldots \ldots \ldots \ldots, 7$

3.1 .1 The Zinc Bromine Cell $\ldots \ldots \ldots \ldots \ldots \ldots \ldots \ldots \ldots \ldots, 7$

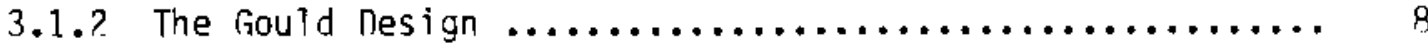

3.1 .3 The Exxon Design $\ldots \ldots \ldots \ldots \ldots \ldots \ldots \ldots \ldots \ldots \ldots, 9$

3.2 EVALUATION OF COST AnAlySES $\ldots \ldots \ldots \ldots \ldots \ldots \ldots \ldots \ldots \ldots \ldots \ldots, 9$

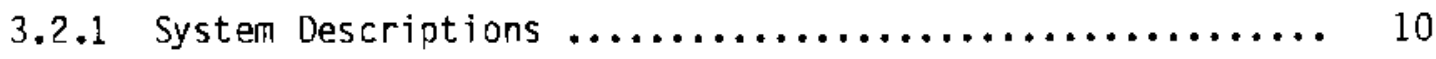

3.2.2 Performance Specifications $\ldots \ldots \ldots \ldots \ldots \ldots \ldots \ldots \ldots, 11$

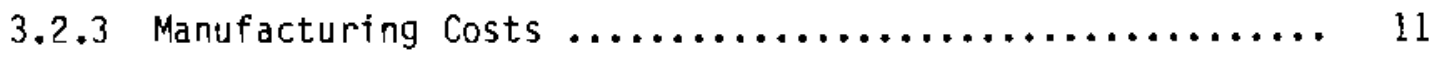

3.2.4 Installed System Costs $\ldots \ldots \ldots \ldots \ldots \ldots \ldots \ldots \ldots \ldots \ldots, 13$

3.2.5 Life-Cycle Costs $\ldots \ldots \ldots \ldots \ldots \ldots \ldots \ldots \ldots \ldots \ldots \ldots, 14$

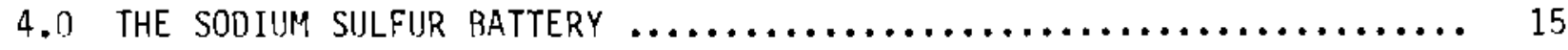

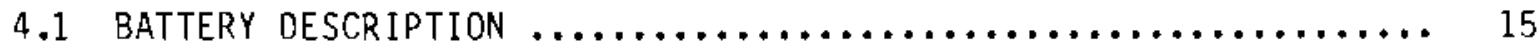

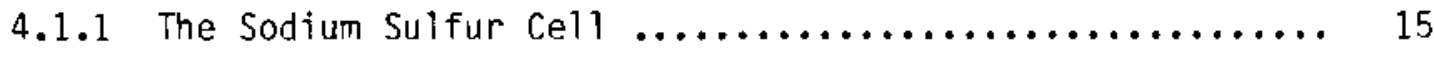

4.1 .2 Battery Design $\ldots \ldots \ldots \ldots \ldots \ldots \ldots \ldots \ldots \ldots \ldots \ldots, 18$

4.? EVALIJATION OF SODIUM SULFUR COST ANALYSES $\ldots \ldots \ldots \ldots \ldots \ldots \ldots .20$

4.2.1 System Descriptions $\ldots \ldots \ldots \ldots \ldots \ldots \ldots \ldots \ldots \ldots, 20$

4.?.? Performance Specifications $\ldots \ldots \ldots \ldots \ldots \ldots \ldots \ldots \ldots \ldots, 22$

4.2.3 Manufacturing Costs $\ldots \ldots \ldots \ldots \ldots \ldots \ldots \ldots \ldots \ldots \ldots \ldots, 22$

4.2.4 Installed System Costs $\ldots \ldots \ldots \ldots \ldots \ldots \ldots \ldots \ldots \ldots \ldots, 24$

4.2.5 Life-Cycle Costs $\ldots \ldots \ldots \ldots \ldots \ldots \ldots \ldots \ldots \ldots \ldots \ldots \ldots, 25$

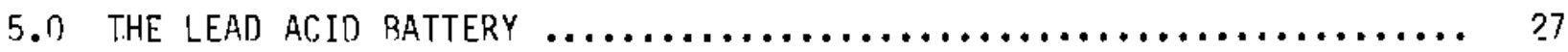




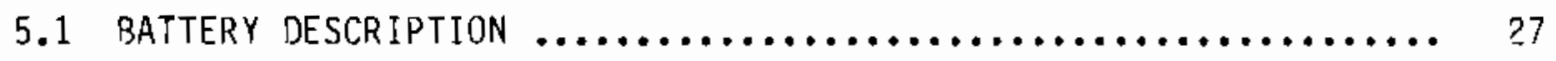

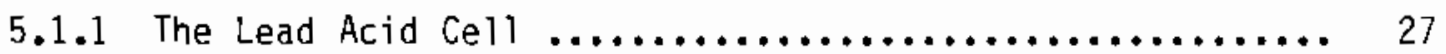

5.1.2 Battery Design $\ldots \ldots \ldots \ldots \ldots \ldots \ldots \ldots \ldots \ldots \ldots \ldots . . . \ldots, 29$

5.2 EVALUATION OF LEAD ACIO COST ANALYSES $\ldots \ldots \ldots \ldots \ldots \ldots \ldots \ldots . . . \ldots \ldots$

5.2.1 System Descriptions $\ldots \ldots \ldots \ldots \ldots \ldots \ldots \ldots \ldots \ldots \ldots \ldots, 33$

5.2.2 Performance Specifications $\ldots \ldots \ldots \ldots \ldots \ldots \ldots \ldots \ldots \ldots, \quad 35$

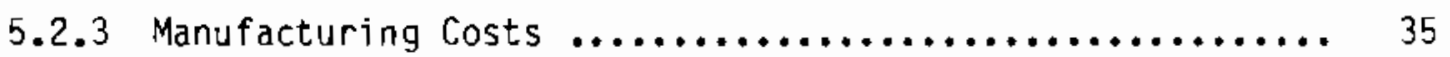

5.2.4 Installed System Costs $\ldots \ldots \ldots \ldots \ldots \ldots \ldots \ldots \ldots \ldots \ldots, 37$

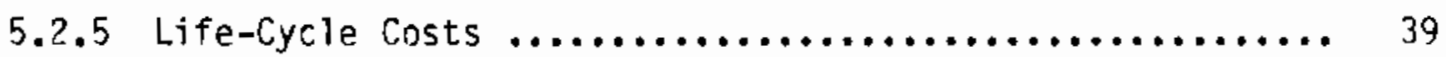

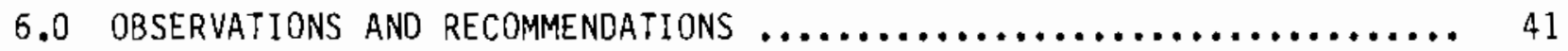

APPENDIX A - ZINC BROMINE CDST DETAILS $\ldots \ldots \ldots \ldots \ldots \ldots \ldots \ldots \ldots \ldots \ldots \ldots \ldots \ldots \ldots \ldots \ldots \ldots \ldots \ldots$

APPENDIX B - SODIUM SULFUR COST DETAILS $\ldots \ldots \ldots \ldots \ldots \ldots \ldots \ldots \ldots \ldots \ldots \ldots \ldots \ldots \ldots \ldots \ldots$

APPENDIX $C$ - LEAD ACID BATTERY CDST DETAILS $\ldots \ldots \ldots \ldots \ldots \ldots \ldots \ldots \ldots . . . \ldots$

APPENDIX D - PUBLICATIONS REVIEWED $\ldots \ldots \ldots \ldots \ldots \ldots \ldots \ldots \ldots \ldots \ldots \ldots \ldots \ldots \ldots \ldots \ldots \ldots \ldots \ldots \ldots$

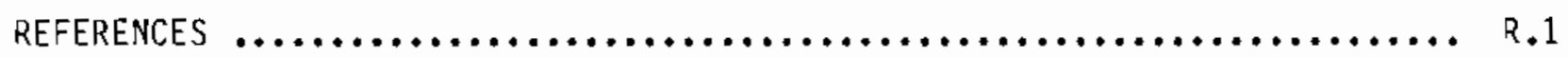


TABLES

2.1 Battery Research 0rganizations Contacted $\ldots \ldots \ldots \ldots \ldots \ldots \ldots \ldots \ldots \ldots$

2.2 Cost Characterizing Information for Battery Systems ............ 4

2.3 GNP Implicit Price Deflators $\ldots \ldots \ldots \ldots \ldots \ldots \ldots \ldots \ldots \ldots \ldots \ldots \ldots \ldots$

3.1 Performance Specifications for the Exxon and Gould Batteries ....... 12

3.2 Non-Normalized Factory Cost Estimates for Zinc Bromine Batteries ........................................ 13

3.3 Non-Normalized Installed System Cost Estimates for Zinc Bromine Batteries .................................. 14

3.4 Non-Normalized Life Cycle Cost Estimates for Zinc Bromine Batteries ........................................... 14

4.1 Performance Specifications for Sodium-Sulfur Batteries .......... 23

4.2 Non-Normalized Factory Cost Estimates for Sodium Sulfur Batteries ............................................ 25

5.1 Performance Specifications for Lead Acid Batteries ............. 36

5.2 Manufactured Cost Estimates for Lead Acid Batteries ............. 37

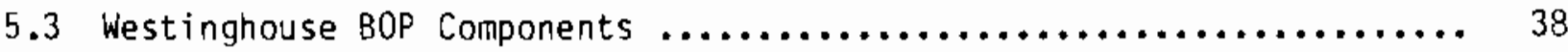

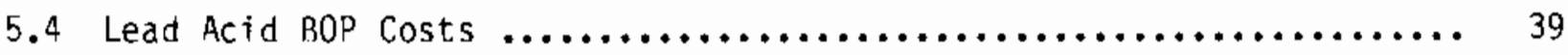

5.5 Non-Normalized Life-Cycle Cost Estimates for Lead Acid Batteries .......................................... 40

6.1 Zinc Bromine/Sodium Sulfur Status Comparison ................ 42 
. 


\subsection{INTRODUCTION}

This report summarizes work completed within the Technology and Economic Analysis (TEA) Program at the Pacific Northwest Laboratory. The long-term objectives of the TEA Program's Battery Cost Analysis Task are to: 1) enhance coordination of battery cost analysis activities, 2) improve the quality of battery system cost estimates, and 3) perform cost-oriented analyses that help the Department of Energy establish goals, develop R\&D plans, and make decisions on R\&D emphasis. Task objectives for FY 1985, and the focus of this report, were to identify the current status of battery system cost analyses and make recomnendations for future work in this area.

Cost analyses for zinc bromine, sodium sulfur, and lead acid batteries were reviewed. Zinc bromine and sodium sulfur batteries were selected because of their advanced design nature and the high level of interest in these two technologies. Lead acid batteries were included to establish a baseline representative of a more mature technology.

Estimates prepared by individual developers were critiqued to identify global problems that existed and to suggest possible remedies. The quality of any single estimate provided by a developer reflects their resources and research focus, among other factors, and the level of quality may vary for reasons beyond the control of any individual developer. 


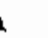




\subsection{APPROACH}

The most recent and thorough cost analyses of zinc bromine, sodium sulfur, and lead acid battery systems were sought for review. Zinc bromine and sodium sulfur battery developers were contacted to ensure that we were working with the latest and/or most detailed analyses. A list of the developers and other organizations contacted is shown in Table 2.1. Current manufacturers of lead acid batteries were not contacted because we were primarily interested in lead acid cost analyses that were completed during its earlier development phase. The lead acid cost analyses served as a benchmark for comparison with zinc bromine and sodium sulfur cost analyses. The time frame of the analysis process limited the review to publications available by the end of 1984 . A complete list of the articles and reports reviewed is presented in Appendix 0.

TABLE 2.1. Battery Research Organizations Contacted

\begin{tabular}{llll}
\multicolumn{1}{c}{ Firm } & \multicolumn{1}{c}{ Contact } & & Technology \\
Dow Chemical & & Charles Levine & Sodium Sulfur \\
ERC & Jim Birk & Several \\
Exxon & Marty Klein & Zinc Bromine \\
Ford Aerospace & Dick Bellows & Zinc Bromine \\
General Electric & Bob Minck & Sodium Sulfur \\
Public Service Electric \& Gas & Bill Auxer & Sodium Sulfur \\
Sandia National Laboratory & Kevin Murphy & Several
\end{tabular}

An essential part of the review process was the developinent of a list of cost characterizing information relevant to battery systems (see Table 2.2). The 1 ist outlines the type of information and level of detail that should be available to fully and adequately evaluate the costs of a battery system. Following a more standard set of estimating guidelines would benefit the cost analysis process by providing more consistency between estimates, more complete estimates, more accurate estimates, and better reproducibility by independent parties. All of these factors would give greater credence to the estimated costs and enhance their usefulness to the R\&D process. 


\section{TABLE 2.2. Cost Characterizing Information for Battery Systems}

System Description Summary

- System Operational Description

- General Features

- Materials of Construction

- System Completeness

Design Specifications

- Power Rating

- Capacity

- Submodule, Module Size

- Series/Parallel Connections

Performance Specifications

- Energy Efficiency (voltaic, coulombic, net)

- Charge and Discharge Rates

- Current Density

- Effective Capacity

Manufacturing (Factory) Cost

- Assembly Procedure/Unit Operations

- Manufacturing Equipment

- General Plant Facilities

- Plant floor Space

- Direct Materials and Labor

Installed System Cost

- FOB Purchase Price

- Shipping

- Field Materials

- Field Labor Hours

Life-Cycle Cost

- Installed System (initial capital cost)

- Battery Replacement

- Salvage Value/Disposal Costs

- Maintenance
- Electrode Size

- Electrolyte Volume

- Battery Weight and Dimensions

- Interface Requirements

- Current and Voltage Ratings

- Cycle Life

- Depth of Discharge

- Peak Power

- Duration of Peak Power

- Overheads

- Profit

- Taxes

- Unit Costs for Material, Labor, Overhead

- Plant Throughput; Operating Schedule

- Auxiliary Equipment/Structures

- Field Indirect Cost Factor

- Fjeld Labor Rate

- Auxiliary Power

- Unit Labor Costs

- Economic Life

- Discount Rate

- Component Escalation Rates 
The list of cost characterizing information is headed by six categories: system description summary, design specifications, performance specifications, manufacturing cost, installed cost, and life-cycle cost. System description and design/performance specifications define the system being costed and serve to identify cost differences among systems steming from differences in system boundary, design type, and performance characteristics. Cost estimating ground rules and assumptions are defined within each of the cost categories. Each category addresses the costing premises and emphasizes the inclusion of ali components pertinent to manufacturing, installed system, and life-cycie costs, respectively.

The battery description provides a qualitative discussion of cell chemistry and battery features and operation. The design specifications describe the battery in a more quantitative way leading to a physical description of the system. Included here is information such as submodule/module size, power rating, capacity, and system configuration (series, parallel, both). The system description summary 1 ists the battery features and discusses the completeness of the system design information. Performance specifications include energy efficiency (voltaic, coulombic, net), charge and discharge rates, battery life, and depth of discharge.

The manufacturing cost estimate includes overheads, taxes, and profit as well as direct materials and labor. The manufacturing characterization also includes a description of the assembly procedure and unit operations. Plant facilities, including specialized equipment, are specified as well. Critical assumptions include labor rates, material costs, plant capacity, and facility life.

Installed system costs include all expenditures necessary to place a battery system in operation at a specific site. Cost components in this category include battery FOB price, transportation, field materials and labor, auxiliary equipment, and design and engineering. Two important assumptions for this category are the field labor rate and field indirect cost factor.

Life-cycle cost components include initial (installed) battery system cost, battery replacement, salvage value or disposal, maintenance, and auxiliary power. Estimation of maintenance costs involves decisions on the time 
allotted for specific tasks as well as the unit labor rate. Important economic assumptions include system economic life, discount rate, and cost component escalation rates.

Each of the battery system cost analyses reviewed was evaluated with regard to the system completeness and level of detail associated with the cost characterizing information described above and presented in Table 2.2. The emphasis of the evaluation was oriented toward determining whether the information presented would allow an independent reconstruction of the estimate and/or reconciliation of estimates from different sources. No attempt was made in this study to validate any single estimate or reconcile two or more estimates to common assumptions. Cost figures presented in the sections that follow have not been normalized to standard assumptions other than the price year. Otherwise, the estimates are as presented in the original sources. The index of GNP price deflators was used to adjust costs from one price year to another. Index values corresponding to calendar years 1975 through 1984 are shown in Table 2.3.

The evaluation of zinc bromine, sodium sulfur, and lead acid batteries follows in Sections 3.0, 4.0, and 5.0, respectively. Each section includes a description of the cells, batteries, and cost analyses that have been developed. Summary cost estimates $(\$ / \mathrm{kWh})$ extracted from the original sources are presented in these sections. Additional cost data supporting the individual estimates are presented in Appendices $A, B$, and $C$. Observations and recommendations are discussed in Section 6.0.

TABLE 2.3. GNP Implicit Price Deflators

$\begin{array}{ll}\frac{\text { Year }}{1975} & \text { Index } \\ 1976 & 125.79 \\ 1977 & 132.34 \\ 1978 & 140.05 \\ 1979 & 150.42 \\ 1980 & 163.42 \\ 1981 & 178.42 \\ 1982 & 195.60 \\ 1983 & 207.38 \\ 1984 & 215.34 \\ & 223.38\end{array}$




\subsection{THE ZINC BROMINE BATTERY}

Zinc bromine battery system cost analyses are described and discussed in this section. Battery cost analyses were reviewed with regard to the completeness and level of detail of their system descriptions and design and performance specifications, as well as manufacturing, installed system, and life-cycle cost estimates. A brief description of zinc bromine cells and batteries is also provided.

\subsection{BATTERY DESCRIPTION}

This section provides a general description of zinc bromine battery technoiogy. The fundamentals of the zinc bromine cell are presented, followed by a discussion of the general design features of the two zinc bromine batteries now being developed.

\subsubsection{The Zinc Bromine Cell}

The cells that compose a zinc bromine battery are based on the reversible reaction between zinc and bromine to form zinc bromide.

$$
\mathrm{Zn}+\mathrm{Br}_{2}+\mathrm{Zn} \mathrm{Br_{2 }}
$$

In its simplest form, the cell consists of an anode and a cathode, an aqueous electrolyte solution of zinc bromide, a conductor connecting the anode and cathode, and a power source. During the charge cycle, the zinc bromide in the electrolyte separates into elemental zinc, which plates out on the anode, and elemental bromine, which forms around the cathode. When the cell is discharged, the elemental zinc and bromine recombine to form the zinc bromide salt. Electricity is generated during discharge by the flow of electrons from the anode to the cathode as elemental zinc is converted to zinc ions. Zinc bromine batteries are appealing for energy storage applications because of their electrochenical simplicity and reversibility.

There are two designs for zinc bromine batteries that are currently being developed. One design originated with Gould Laboratories and was further developed by Fluor Engineers and Energy Research Corporation (Gould battery). 
The other design originated with Exxon Research and Engineering Company (Exxon battery). Although the two battery designs are generally similar, there are some differences that affect the cost estimates. The following two subsections will discuss the similarities and differences between the Exxon and Gould batteries. The adequacy of the design information is discussed in section 3.2.

\subsubsection{The Gould Design}

When work on the Gould battery was taken over by Fluor and ERC, design emphasis changed from an $80 \mathrm{kWh}$ module developed for photovoltaic applications to a $500 \mathrm{kWh}$ battery system that could be tested at the Battery Energy Storage Test (BEST) facility. The $500 \mathrm{kWh}$ battery is composed of 30 submodules (3.33 kW ea) submodules with a discharge voltage of 83.3V each (Monn 1983). The cell stacks use the same design as the $80 \mathrm{kWh}$ battery. However, the most recent cell design described in an unpublished report substituted carbonplastic composite electrodes, in order to save costs. The stacks can be held together either by compression with strongback assemblies, or by heat sealing of the plastic components.

The submodules are hydraulically connected in 10 parallel sets, with three parallel submodules per set. The anolyte system includes a heat exchanger and a hydrogen bromine recombiner made of a coiled bed of catalyst. The catholyte system includes a static mixer and a bromine storage facility. These systems also include punps, piping, storage tanks, and controls. The electrolyte feeder lines contain rotating vanes used to momentarily interrupt the electrolyte flow. This has the effect of increasing the resistance through the electrolyte, so that shunt current losses through the electrolyte manifolds witl be reduced.

The 30 submodules are electrically connected in series and parallel. Three submodules are connected in parallel per group, five groups are linked in series per string, and the two strings are parallel-connected. The resulting $500 \mathrm{kWh}$ battery can deliver 240 amps at 416.7 volts for five hours. The electrical system includes cabling, temperature switches, fuses, ammeters, and a control panel. 


\subsubsection{The Exxon Design}

The Exxon zinc bromine battery chemistry is similar to the Gould battery and many design principles are also currently similar. However, there are specific engineering differences between them, which affect their cost and iifetime estimates.

A $20 \mathrm{kWh}$ battery was used as the basis for Exxon's cost estimate (Bellows 1983a, 1983b). This battery has two stacks of 78 bipolar cells each, connected in parallel. Each electrode has an area of $1200 \mathrm{~cm}^{2}$. The nominal discharge is 120 volts. The cells are manufactured by a co-extrusion process for the electrode, the separator material is extruded, and the separator frame is injected molded. The carbon plastic electrodes are less expensive than those made of pure carbon used by Gould, but they may have a shorter lifetime (Bechtel 1982).

As with the Gould design, the electrolyte is divided into separate anolyte and catholyte circulation systems. The anolyte system includes heat rejection via plastic coils carrying forced cooled air, and a hydrogen bromine recombiner. The catholyte system includes a reservoir for the polybromide complex, but does not need a static mixer; dispersal of the bromine complex in the electrolyte is achieved through normal pumping action. Centrifugal pumps are used, and piping and reservoirs are also includer.

Shunt currents from the cells through the electrolyte manifold are prevented by using "tunnel" shunt current protection. This method uses connections (tunnels) between the channels which connect the manifolds to the cells. A protective current is passed through the common electrolyte network from the first channel/tunnel to the last channel/tunnel. The voltage drop through each tunnel, which results from this current, is equal to the voltage of the cell. The electrical system for the Exxon battery also includes instrumentation, controls, busbars, tie rods, and miscellaneous hardware.

\subsection{EVALUATION OF COST ANALYSES}

This section evaluates the adequacy of previous cost data and cost analyses developed for zinc bromine batteries. The structure of this section 
closely follows the list of cost characterizing information presented in Table 2.2. The adequacy of information is captured in the system completeness and level of detail associated with the cost analyses reviewed.

\subsubsection{System Descriptions}

Design information for the two zinc bromine battery types should exist in sufficient detail to determine specific similarities and differences, if accurate cost comparisons are to be possible. The designs should include not only the battery itself, but should also describe the system in which the battery will be used so that the installation arrangements and auxiliary equipment can be compared. This section will discuss the system descriptions for the Gould and the Exxon batteries.

The design specifications for the $500 \mathrm{kWh}$ battery system intended for the BEST facility (Gould battery) are comprehensive for that facility. The report describes the construction of the cells in the submodule stacks and the stack assembly, and presents the following information: 1) diagrams of process flow, piping, and mechanical flow for the electrolyte systems, 2) a photograph of a 3-D model of the completed battery system, 3) wiring diagrams, 4) 1ists of instruments, controls, and equipment, and 5) startup and shutdown procedures (Monn 1983). These design specifications are for a conceptual facility only; the largest battery size that had actually been constructed at the time of this review was $80 \mathrm{kWh}$.

Some of the auxiliary equipment required by the battery system was available at the BEST facility, and was therefore excluded from the design specifications for the BEST battery. Excluded items were power conditioning equipment, foundations, cranes for battery unloading, fire protection systems, and sewer drainage connections for cooling water and power. The battery could not be considered to be a stand-alone unit without these items. If the $500 \mathrm{kWh}$ Gould battery system were used in any other application besides the BEST facility, the excluded items would need to be included in the design specifications.

Publicly available design specifications for the Gould battery do not include the most recent changes in cell construction. An unpublished $E R C$ report indicates that carbon plastic is now being used for the electrode. This 
could alter the cell construction, might alter the hydraulic and electrical connections, and would definitely affect the cost estimate.

The design information for the Exxon two-stack battery describes the manufacture of the two-piece unit cell with co-extruded electrodes and extruded separators, discusses shunt current protection design factors, describes the flow frame design selected for the cells, lists the dimensions of electrodes, frames, channels and manifolds, and includes a schematic drawing of the cell construction. Hydraulic components such as pumps, reservoirs, and electrolyte are the same as the ones used for their earlier six-stack battery design. However, no design information was presented for the system that would use the $20 \mathrm{kWh}$ battery module. No system configurations have been suggested, so the interbattery hydraulic and electrical connections that would be necessary for battery installation have not been described. Information about the auxiliary equipment and the structural supports needed for a battery installation are a) 50 needed in order to allow a complete design comparison between the two zinc bromine batteries.

\subsubsection{Performance Specifications}

The performance specifications define the functions of the battery systems and include ratings of capacity, output, efficiencies, loading, and charge/ discharge time. Performance specifications are needed, along with design specifications, to ensure cost comparability between different battery systems. The performance specifications are listed in Table 3.1 for the Exxon and the Gould batteries.

The designers of the Gould 500 kWh battery system, Fluor and ERC, could have intended the energy efficiency, electrode size, depth of discharge, and expected lifetime to be the same as the $80 \mathrm{kWh}$ battery developed by Gould. If this is the case, the performance specification information needed that wil1 allow a system comparison would be current density, zinc loading, and peak power for the Gould battery.

\subsubsection{Manufacturing Costs}

Each of the reports reviewed included an estimate of the factory (manufaccured) cost of the battery. The quality of the estimates varied, but some 
TABLE 3.1. Performance Specifications for the Exxon and Gould Batteries

\begin{tabular}{|c|c|c|}
\hline Specification & Gould & Exxon \\
\hline Nominal Capacity & $500 \mathrm{kWh}$ & $20 \mathrm{kWh}$ \\
\hline Voltage Oelivered & $916.7 \mathrm{~V}$ & $120 \mathrm{~V}$ \\
\hline Current Delivered & 240 amps & 55.5 amps $(a)$ \\
\hline Charge/Discharge Rate & 5 hours & 3 hours \\
\hline Overa11 Energy Efficiency (b) & $65-70 \%(c)$ & $65-70 \%$ \\
\hline Electrode Size & $929 \mathrm{~cm}^{2(c)}$ & $1200 \mathrm{~cm}^{2}$ \\
\hline Zinc Loading & -- & $94 \pi \mathrm{Ah} / \mathrm{cm}^{2}$ \\
\hline Peak Power & -- & $26 \mathrm{kw}$ \\
\hline Depth of Discharge & $80 \%(c)$ & $80 \%$ \\
\hline Expected Lifetime & $2500+$ cycles $(c)$ & $1000+$ cycles \\
\hline
\end{tabular}

(a) Calculated from data available.

(b) Obtained by multiplying vottaic and coulombic efficiencies.

(c) Performance specifications for the Gould $80 \mathrm{kWh}$ battery.

general observations can be made. The assembly process is usually not described in enough detail to substantiate labor and floor space estimates and/or allow for an independent analysis of the estimate. An exception would be the description of manufacturing operations in Monn (1983). Manufacturing plant equipment descriptions were lacking in all of the reports evaluated. Several reports contained estimates for incomplete systems; however, the most recent estimates for both the Exxon and Gould batteries include the majority of direct and indirect cost components that might be included.

Most of the reports used the A. D. Little (ADL) guidelines (George 1979) for estimating factory $F 0 B$ costs from estimates of direct material and labor, factory floor space, and factory equipment costs. The ADL method provides a standardized approach to developing factory $F O B$ costs and is relatively simple 
to apply, but should probably be modified to reflect changes in depreciation laws that have occurred since the model was first developed. It may be better to develop a new approach based on levelized production cost. This would allow a more accurate treatment of capital and expense cash flows over the life of a manufacturing facility.

Estimates of factory costs for $\mathrm{ZnBr}_{2}$ batteries are presented in Table 3.2. These estimates are as published in each of the reports, except for adjustment to 1984 dollars. No attempt has been made to reconcile the estimates to a standard set of assumptions. Supporting details for the manufacturing cost estimates are presented in Appendix $A$.

\subsubsection{Installed System Costs}

Dniy three of the reports reviewed contained a complete estimate of installed system cost. Installed costs were estimated by Bechtel (1982) for both the Gould and Exxon batteries. Their estimates were extremely detailed and addressed all of the major cost components associated with field installation for a battery except power conditioning. Gould estimated installed system costs for their battery (Ramsay 1982), but several components (such as power conditioning, shipping, and field labor) were not included. Fluor/ERC (Monn 1983) estimated an installed system cost for the Gould battery based on a 500 kwh module designed for the BEST facility. Their estimate also lacked power conditioning equipment and other auxiliaries. Table 3.3 presents the estimates for installed system costs as prepared by Bechtel, Gould, and Fluor/ERC with

TABLE 3.2. Non-Normalized Factory Cost Estimates for Zinc Bromine Batteries

\begin{tabular}{|c|c|c|}
\hline Source & Battery Design & $1984 \$ / \mathrm{kWh}$ \\
\hline Bechtel 1982 & Gould & $120-172$ \\
\hline Bechtel 1982 & Exxon & $44-67$ \\
\hline Bellows $1983 \mathrm{~b}$ & Exxon & 50 \\
\hline Monn 1983 & Gould & 106 \\
\hline Ramsay 1982 & Gould & 86 \\
\hline Bellows 1983a & Exxon & 35 \\
\hline
\end{tabular}


TABLE 3.3. Non-Normalized Installed System Cost Estimates for Zinc Bromine Batteries

\begin{tabular}{|c|c|c|}
\hline Source & Battery Design & $1984 \$ / \mathrm{kWh}$ \\
\hline Bechtel 1982 & Exxon & $121-216$ \\
\hline Bechtel 1982 & GouTd & $237-379$ \\
\hline Ramsay 1982 & Gould & 117 \\
\hline Monn 1983 & Gould & 524 \\
\hline
\end{tabular}

adjustment to 1984 dollars. No attempt was made to reconcile the estimates to a standard set of assumptions. Supporting details for the installed cost estimates are presented in Appendix $A$.

\subsubsection{Life-Cycle Costs}

Bechtel (1982) and Ramsay (1982) were the only two reports which included estimates of life-cycle cost. Both sources included all of the major lifecycle components in their estimates. Bechtel explicitly included the cost of energy losses due to system inefficiencies at $5 \$ / k w h$. A real discount rate of $2 \%$ was employed by Bechtel. The Ramsay analysis used real discount rates of $6 \%$ and $8 \%$ in his calculations.

The 1 ife-cycle costs estimated by Bechtel and Ramsay are presented in Table 3.4. These estimates are as published in the two reports, with adjustment to 1984 dollars. No attempt has been made to reconcile the estimates to a standard set of assumptions. Supporting details for the life-cycle cost estimates are presented in Appendix A.

TABLE 3.4. Non-Normalized Life-Cycle Cost Estimates for Zinc Bromine Batteries

\begin{tabular}{|c|c|c|}
\hline Source & Battery Design & $1984 \$ / \mathrm{kWh}$ \\
\hline 8echtel 1982 & Exxon & $348-634$ \\
\hline Bechtel 1982 & Gould & $420-738$ \\
\hline Ramsay 1982 & Gould & $188-193$ \\
\hline
\end{tabular}




\subsection{THE SODIUM SULFUR BATTERY}

Sodium sulfur battery system cost analyses are described and discussed in this section. Battery cost analyses were reviewed with regard to the completeness and level of detail of their system descriptions and design and performance specifications, as well as manufacturing, installed system, and life-cycle cost estimates. A brief description of sodium sulfur cells and batteries is a] so provided.

\subsection{BATTERY DESCRIPTION}

This section provides a general description of sodium sulfur battery technology. The fundamentals of the sodium sulfur cell are presented. This is followed by a comparison of general design features of different cells and a description of batteries now being developed.

\subsubsection{The Sodium Sulfur Cell}

The cells that compose a sodium sulfur battery are based on the reversible reaction between liquid sodium and liquid sulfur to form liquid sodium polysulfide.

$$
2 \mathrm{Na}+\mathrm{yS}+\mathrm{Na}_{2} \mathrm{~S}_{\mathrm{y}}
$$

Sodium is the anode for this cell, sulfur is the cathode, and the electrolyte is usually beta"-alumina. During charging, the sodium polysulfide is broken down into sodium and sulfur; during discharge, the reaction is reversed. The exact proportion of recombinant sodium and sulfur in the sodium polysulfide will vary, ranging from $\mathrm{Na}_{2} \mathrm{~S}_{5}$ to $\mathrm{Na}_{2} \mathrm{~S}_{2}$, depending on the depth of discharge. The potential advantages of the sodium sulfur cell are that raw materials are abundant and inexpensive and that the cell has high energy efficiency and energy density.

Sodium sulfur cell designs differ to a much greater extent than zinc bromine cell designs. Three NaS cell designs will be described in more detail: one developed by General Electric, one developed by Ford Aerospace, and one 
developed by Dow Chemical. Each company has tested severat cell designs. The designs described in this report were those that served as the basis for their battery cost estimates.

\subsubsection{The General Electric Cell}

General Electric, in conjunction with Chloride Silent Power, Ltd., has developed two different types of NaS cells. The first type, referred to as the NaS7, is intended primarily for electric vehicie use. This design features the sulfur electrode on the inside of the electrolyte, and the sodium on the outside. The NaS7 cell features good reliability and a long lifetime, mostly because there are fewer corrosion problems if the sulfur is in the center (Roberts 1984). However, since cell capacity is related to the amount of sulfur, the central sulfur cell has a lower capacity and, therefore, is a more expensive way to store power (Wicker 1979). The central sulfur configuration might be preferred for applications where safety is emphasized more than cost.

The second cell type, referred to as the FII cell, is intended primarily for load-leveling applications. The FII cell has an upper sodium reservoir, an inner core of sodium, a beta"-alumina electrolyte, an outer well of sulfur, and a chromized steel outer container. The sulfur electrode contains carbon fibers to act as a wick. The seal between the electrolyte and the reservoir is made of alpha-aiumina ceramic and a borosilicate glass to bond the alpha-alumina to the beta"-alumina. There is also a sleeve around the sodium container to help reduce stress on the seal. The fII cell has twice the current density of the NaS7 cell, and has a lower projected cost.

\subsubsection{The Ford Cel1}

Ford Aerospace has also developed sodium sulfur cells for electric vehicles and load-leveling applications. The cells for both uses are of similar design, with the main difference being that the electric vehicle cells have a smaller capacity and a shorter charge/discharge cycle. The cell that has received the most testing and cost analysis is called the Mark-II, developed for load-leveling applications (Harlow 1984).

The Mark-II cell configuration is similar to the GE FII cell in many respects. The arrangement of sodium, wick, sulfur, and electrolyte is the 
same. The main differences are in engineering design of safety components, methods of production, and materials for seal construction. The sulfur electrode is made up of twelve wedge-shaped electrode strips, which contain graphite felt and a carbon mat for wicking. A metering-bulkhead/safety tube is inserted on the inside of the sodium wick to prevent uncontrolled reaction of the sodium and sulfur. The radial compression seal used to assemble the upper and lower containers of the cell uses metallic aluminum gaskets between the alpha-alumina header and the electrolyte tube, rather than borosilicate glass. Another difference between the Mark II and the FII cells is in the manufacture of electrolyte. The electrolytes used by Ford Aerospace were produced by isostatic pressing of the dry powder to form the desired shape before sintering, rather than using electrophoretic deposition. Ford Aerospace considers the isostatic pressing method to be more economical.

\subsubsection{The Dow Cell}

The sodium sulfur cell being developed at Dow Chemical is completely different from either the ford or the GE cell. Its description is included here because it illustrates the range of possible designs for the NaS cells. The Dow Chemical design does not use a beta"-alumina electrolyte. A specially developed borate glass, shaped into fine hollow fibers, is used instead. Sodium anolyte is on the interior of the fibers, and sulfur catholyte is on the exterior. Cell resistance is low because the ion path is short, and the thousands of fibers act as parallel resistances. The glass fibers are interspersed with coated aluminum foil, which acts as a cathode current collector. The cell assembly consists of a foil-fiber assembly immersed in the sulfur-polysulfide melt with the sodium reservoir at the top. The upper and lower containers can be made of aluminum rather than coated steel.

The potential advantages of this cell design include: 1) cell operation at very low current density, 2) less expensive hollow glass fibers, 3) greater design flexibility with regard to the desired energy and power levels, and 4) greater cell reliability (Levine 1981). 


\subsubsection{Battery Design}

This section will qualitatively describe battery designs that use the ford and General Electric cells. The designs selected were the ones used as the basis for the cost analyses that were reviewed. Quantitative performance specifications are listed and compared in Section 4.2.2.

\subsubsection{The Ford Battery}

The conceptual design for the Ford battery has a nominal rating of $20 \mathrm{MW}$ or 100 MWh. An installed capacity of 132 MWh allows for cell failures and performance degradation over the battery lifetime. Typical charge time is 7 to 10 hours, with a 5 -hour discharge time. The battery design was evaluated with two different options: 1) using smaller 211 Wh cells, or 2) using larger, 402 Wh cells. The smaller cell has a rated capacity of $130.2 \mathrm{Ah}$, a discharge current of A26, and a discharge voitage of $1.6 \mathrm{~V}$. The larger cell has a rated capacity of 249.2 Ah, a discharge current of A49.8, and a discharge voltage of V1.6. Details of the cell configurations were discussed in Section 4.1.1.?.

The smaller-cell battery is assembled in the following way: 96 cells are arranged in parallel to form a submodule. Five submodules are arranged on a tray, and there are two trays per module. One hundred twelve modules are connected in a series to make a unit battery string. This string has a discharge current of A2600, an average discharge voltage of V1850, and an end-of-charge voltage of V2600. Five unit battery strings are connected in parallel for the 100 MWh stationary energy storage (SES) battery. The larger-cell battery also has 96 cells per submodule, but there is only one tray with five submodules per module. The larger-cell battery thus has half the number of cells per module as the smaller-cell battery. Extra modules are added to allow for the lower reliability that a smaller number of larger tubes would have.

The SES facility includes a power converter to provide an interface with the utility power grid. Electrical connections within the battery are provided by spider busbars made of aluminum. Forced-air cooling is used for temperature control. Modules are removed from the unit battery structure for maintenance 
or replacement. Preliminary data indicate that the cells could tolerate cooling to room temperature before removal and repair, which would improve the ease of maintenance.

\subsubsection{The General Electric Batteries}

General Electric has published a cost estimate for a 100 MWh rated utility load leveling battery that uses their FII cell. This cell is described in Section 4.1.1.1. Unfortunately, relatively little information about the design configuration of this battery system was presented (Roberts 1984). Therefore, this section will also discuss the design developed by Compagnie Generale D'Electricite (CGDE) of Marcoussis, France (Wicker 1981). This design inciudes a more complete set of cost and technical information. The CGDE design is based on a cell of optimized size that uses a beta"-alumina electrolyte. This cell had a smaller capacity than the FII cell, but the energy density and volumetric density were higher.

The $100 \mathrm{MWh}$ battery designed for the FII cell was made from approximately 132,000 cells. Each cell has a design capacity of Ah447 with a theoretical capacity of Ah658, a discharge current of A89, a discharge voltage of V1.7, power rating of $W 152$, and an energy rating of $765 \mathrm{Wh}$. The rated capacity includes a $15 \%$ excess for loss of capacity due to cell failure. Charge time is 7 hours and discharge time is 5 hours. The cells are arranged in the following way: 36 cells are assembled into a module, 363 modules are arranged in series to form a string, and 10 strings in parallel are connected to form the battery. Further details of the battery configuration had not been determined.

The battery system designed by CGDE is a $100 \mathrm{MWh}$ system requiring $2.27 \mathrm{x}$ $10^{5}$ cells that use a beta"-alumina electrolyte. The number of cells includes the theoretical requirement, plus an excess to allow for cell failure and for capacity losses associated with connecting large numbers of cells in paralle1. Each cell has a useful energy of 523 Wh, a charge time of seven hours, a discharge time of 10 hours, a maximum capacity of Ah309, and an energy efficiency of $80.3 \%$. The cells are arranged as follows: 26 cells are connected in parallel to make a submodule, four submodules are connected to make a module, 436 modules are connected in a series to make a string, and five strings are connected in parallel to make a battery. 
Thermal management for the battery is provided with nitrogen and with a minimal amount of foamed concrete insulation. The parallel nitrogen channels have a Targe cross section, and are made of refractory concrete. This arrangement allows lower pumping energy, although it requires a lot of space. Each string contains an independent nitrogen circulation system, which is located at the far end of the unit. A separate loop is incorporated for startup, and encloses the heat exchangers needed for the initial heating period. Thermal energy recovery is not used because the high battery efficiency reduces the economic value of a recovery system. The busbars used for current collection are made of aluminum.

\subsection{EVALUATION OF SODIUM SULFUR COST ANALYSES}

This section evaluates the adequacy of previous cost data and cost analyses developed for sodium sulfur batteries. The structure of this section closely follows the list of cost characterizing information presented in Table 2.2. The adequacy of information is captured in the system completeness and level of detail associated with the cost analyses reviewed.

\subsubsection{System Descriptions}

Design information for the batteries developed by Ford and General Electric should exist in sufficient detail to determine specific similarities and differences, if accurate cost comparisons are to be possible. The designs should include not only the battery itself, but should also describe the system in which the battery will be used so that the installation arrangements and auxiliary equipment can be compared. This section will discuss the system descriptions developed by Ford and General Electric.

Design information for the Ford load-ieveling battery module is developed in detail. Flow charts thoroughly describe the process steps needed to prepare the electrolyte, the alpha-alumina header, the alpha-alumina seal, and the cell assembly. These flow charts provide a good idea of the design and manufacturing techniques used for the cells that make up the battery. A very clear exploded diagram of an assembled cell is included, which is a useful way to quickly demonstrate cell configuration. There is a diagram that shows how the cells are connected to form a submodule and how the suhmodules are stacked in a 
module. Another drawing shows the arrangement of the modules, the air cooling manifold, the insulation, the enclosure cover, and the module controller within the unit battery. The battery design also includes thorough discussions of the rationales for various design choices, such as a discussion of the advantages of aluminum busbars, various cooling options, design optimization for minimum cost and energy loss, and requirements for module controls.

The design information describing the incorporation of the units into a utility load leveling system, however, is less detailed. Site-specific information describing the power conditioning equipment, foundations, fire protection equipment, power connections, and construction requirements is not included. Little information is presented regarding maintenance requirements. Site assembly of a complete system from a 20 Mwh unit battery should also be described to allow a complete cost analysis of the battery system.

The General Electric report on the FII cell battery system includes a comprehensive discussion of individual cell components, cell performance testing, safety, and cell failure, but very little discussion of utility cell assembly. Battery design information includes an evaluation of maintenance and cell efficiency requirements. However, the series-parallel arrangement of cells in the battery had not been determined, nor had the cooling system or the electrical connections. There is a diagram showing how unit batteries might be assembled into a load-leveling system, but no details were included.

Battery design for the FII cell was not complete for the battery or the load-leveling system, therefore we also reviewed information about the battery design developed by Compagnie Generale D'Electricite (CGDE). The CGDE report provides a thorough discussion of the manufacturing options for the electrolyte, and describes the process steps very clearly and in great detail. Design information for the cells even includes the dimensions of the busbars and the thermal insulation requirements. For the unit battery, there is a description of the complete thermal management system, including cooling, heat exchangers, fan, and startup heat requirements. The load-leveling battery system description also includes yardwork, engineering and construction planning, control room equipment, and installation requirements. 
The report by CGDE provided comprehensive information about the electrolyte, but the descriptions of the cells, modules, and batteries lacked information about assembly and assembly methods. Descriptions of the arrangement of cells in the module or of modules in the unit battery were limited. Power conversion equipment was not included in the design nor was a rationale for estimated labor hours included.

\subsubsection{Performance Specifications}

The performance specifications define the functions of the battery systems and include ratings of capacity (both theoretical and nominal), discharge energy, voltage and current, efficiencies, charge/discharge time, and energy density. Performance specifications are needed, along with design specifications, to ensure cost comparability between different battery systems. The performance specifications are listed in Table 4.1 for the small and large-cell Ford battery, the GE FII cell battery, and the CDGE battery.

The performance specifications are complete, except for the following:

1. Theoretical capacity of the GE and CGDE batteries for the rated $100 \mathrm{MWh}$ battery. This would be higher than the rated value, depending on the assumptions made for the number of additional cells that would be needed to ensure that battery capacity does not fall below the rated value. The assumptions would include information such as expected failure rate and resistance rise.

2. Energy footprint information for the GE and CGDE batteries which indicates the efficiency of a battery system in relation to its size.

3. Theoretical capacity of the CGDE cell, which would normally be higher than the rated capacity to allow for resistance losses.

4. CGDE battery discharge current.

\subsubsection{Manufacturing Costs}

Several manufacturing cost estimates have been completed hy the sodium sulfur battery developers and their subcontractors. The estimates vary significantly in their level of detail, completeness, date of publication, and their bottom line cost per kilowatt-hour. Each of the more significant reports reviewed is discussed below. 
TABLE 4.1. Performance Specifications for Sodium Sulfur Batteries

\begin{tabular}{|c|c|c|c|c|}
\hline \multirow[b]{2}{*}{ Specification } & \multicolumn{2}{|c|}{ Ford } & \multirow[b]{2}{*}{ GE } & \multirow[b]{2}{*}{ CGDE } \\
\hline & Small Cell & Large Cell & & \\
\hline Cell Discharge Energy & 211 wh & $4 D 2$ wh & 765 Wh & 523 wh \\
\hline Cell Theoretical Capacity & 186 Ah & 356 Ah & 658 Ah & -- \\
\hline Cell Rated Capacity & $130 \mathrm{Ah}$ & 249 Ah & $447 \mathrm{Ah}$ & 309 Ah \\
\hline Cell Discharge Voltage & $1.6 \mathrm{~V}$ & $1.6 \mathrm{~V}$ & $1.7 \mathrm{~V}$ & $1.7 \mathrm{~V}$ \\
\hline Cells/Battery & 537,600 & 288,000 & 131,000 & 227,000 \\
\hline Cell Efficiency & $\begin{array}{l}80 \% \text { max } \\
75 \% \text { min }\end{array}$ & $\begin{array}{l}80 \% \text { max } \\
75 \% \text { min }\end{array}$ & $75-80 \%$ & $80 \%$ \\
\hline Rated Battery Discharge & $100 \mathrm{MWh}$ & $100 \mathrm{MWh}$ & $100 \mathrm{MWh}$ & $100 \mathrm{MWh}$ \\
\hline Theoretical Battery Capacity & 131 MWh & $134 \mathrm{MWh}$ & -- & -- \\
\hline Battery Discharge Current & $15,100 A^{(a)}$ & $15,200 \mathrm{~A}^{(a)}$ & $32,150 \mathrm{~A}$ & -- \\
\hline Battery 0ischarge Voltage & $1000 \mathrm{~V}$ & $1000 \mathrm{~V}$ & $636 \mathrm{~V}$ & $1000 \mathrm{~V}$ \\
\hline Charge Time & $7-10 \mathrm{hr}$ & $7-10 \mathrm{hr}$ & $7 \mathrm{hr}$ & $5 \mathrm{hr}$ \\
\hline Discharge Time & $5 \mathrm{hr}$ & $5 \mathrm{hr}$ & $5 \mathrm{hr}$ & $5 \mathrm{hr}$ \\
\hline Energy Footprint & $8 \mathrm{kWh} / \mathrm{ft}^{2}$ & $8 \mathrm{kWh} / \mathrm{ft}^{2}$ & -- & - \\
\hline Energy Efficiency & $75 \%$ & $75 \%$ & $75 \%$ & $75 \%$ \\
\hline Nominal Lifetime & $10 \mathrm{yr}$ & $10 \mathrm{yr}$ & $30 \mathrm{yr}$ & $10 \mathrm{yr}$ \\
\hline
\end{tabular}

(a) Calculated from available data.

A report prepared by Ford Aerospace (1980) contained one of the more detailed manufacturing analyses that we reviewed. The Ford report contains very detailed process flow diagrams, along with material unit cost data, equipment lists, and a manufacturing facility that was explicitly sized based on equipment floor space requirements. Unfortunately, several design changes have occurred since the estimate was made in 1980.

General Electric (8ast 1982, Roberts 1984) has published more recent reports with manufacturing cost estimates for their sodium sulfur battery. Unfortunately, their reports only provide summary cost information. Little substantiation or basis is given for the equipment, labor, and materials figures presented. 
The most detailed battery cost estimate for a GE design was included in a report completed by Compagnie Generale D'Electricite (CGDE) (Wicker 1981). The CGDE report was primarily focused on the cost of producing beta"-alumina electrolyte tubes. The evaluation investigated alternative tube sizes and processing routes and compared tube costs manufactured from beta and beta"-alumina. The report included detailed descriptions of the manufacturing processes and itemized labor and material lists, but limited description of the equipment requirements.

A detailed analysis of beta"-alumina electrolyte tube costs was completed for Ford by Ceramatec (1980). The Ceramatec study was similar to that performed by CGDE for General Electric. Ceramatec's analysis included an examination of different tube sizes, different processing routes, and the availability of low cost raw materials.

The most recent estimate of the sodium sulfur cell developed by Dow Chemical was completed in 1981. The report by Levine (1981) provides detailed descriptions of unit operations and material, labor, and equipment requirements at the unit operation level. The report includes the cost of manufacturing the cells but not the cost of a complete battery system.

All of the reports mentioned above used the A. D. Little guidelines for estimating factory $F O B$ costs. Using the guidelines facilitates the evaluation of the estimates by normalizing many of the economic assumptions and grouping costs in consistently defined categories. Factory $F O B$ costs are presented in Table 4.2. These estimates have all been adjusted to 1984 dollars, however, no attempt has been made to reconcile any other differences in assumptions. Supporting details for the manufacturing cost estimates are presented in Appendix $B$.

\subsubsection{Installed System Costs}

Only two of the reports evaluated included an estimate of installed system cost for a sodium sulfur battery. Bechtel (1982) estimated the cost for a battery system installed in a photovoltaic power application. The Bechtel estimate selected the Ford Aerospace design as their baseline. Battery prices (FOB 
TABLE 4.2. Non-Normalized Factory Cost Estimates for Sodium Sulfur Batteries

\begin{tabular}{|c|c|c|}
\hline Source & Battery Design & $1984 \$ / \mathrm{kWh}$ \\
\hline Roberts $1984 \mathrm{a}$ & General Electric & 71 \\
\hline Wicker 1981 & General Electric & 87 \\
\hline Bechtel 1982 & Ford Aerospace & $126-159$ \\
\hline Sernka 1984 & Ford Aerospace & $89-94$ \\
\hline Ford 1980 & Ford Aerospace & 105 \\
\hline Levine 1981 & Dow Chemical & $45^{(a)}$ \\
\hline
\end{tabular}

(a) Cost estimate is for the cell only

factory) were based on information in Ford (1980) and studies from other sodium sulfur battery developers. Bechtel modified the developer's estimates based on their assessment of design completeness, material costs, manufacturing and assembly, operations, and cost of manufacturing facilities.

Bechtel's installed battery cost estimate was aggregated from material and labor costs for installation components. Major components included shipping, building, thermal management, instrumentation and electrical. The basis for each of the component estimates was substantiated by a detailed design description. The total installed cost was estimated to range from $\$ 199$ to $272 / \mathrm{kWh}$ in 1984 dollars. CGOE developed the other installed sodium sulfur battery cost estimate that we reviewed. The CGDE estimate included major system components such as yardwork, civil and structural work, cooling and heating equipment, and control room equipment, but lacked detajled descriptions of the plant facilities or other cost bases and did not include converter costs. Their installed system cost estimate was $\$ 105 / \mathrm{kwh}$ in 1984 dollars. Supporting details for the installed system cost estimates are presented in Appendix B.

\subsubsection{Life-Cycle Costs}

Bechtel (1982) was the only report evaluated that estimated life-cycle costs for a sodium sulfur battery. The Bechtel estimate included all the major contributors to a life-cycle cost such as installed costs, salvage, maintenance, and energy losses. Battery replacement was assumed to be all at once 
for all of the modules. An initial redundancy of $16 \%$ was built into the battery to allow for a 10 -year life before complete replacement. The total lifecycle cost was estimated by Bechtel to range from $\$ 404-\$ 602 / \mathrm{kWh}$ in 1984

dollars. Supporting details for the life-cycle cost estimate are presented in Appendix B. 


\subsection{THE LEAD ACID BATTERY}

Lead acid battery system cost analyses are described and discussed in this section. Battery cost analyses were reviewed with regard to the completeness and level of detail of their system descriptions and design and performance specifications, as well as manufacturing, installed system, and life-cycle cost estimates. A brief description of lead acid cells and batteries is also provided.

\subsection{BATTERY DESCRIPTION}

This section provides a general description of lead acid battery technology. The fundamentals of the cell chemistry are presented, along with tradeoffs in cell design, differences in cell types, and the general design features of different hatteries that have been developed from the lead acid cells.

\subsubsection{The Lead Acid Cell}

The electrochemical reaction that drives the so-called lead acid cell is between sponge lead, which functions as the negative electrore, and lead dioxide, which functions as the positive electrode. In an aqueous solution of sulfuric acid, the lead and lead dioxide are reversibly converted to lead sulfate and lead oxide. The overall chemical reaction is as follows:

$$
\begin{gathered}
2 \mathrm{~Pb}+2 \mathrm{PbO}_{2}+2 \mathrm{H}_{2} \mathrm{SO}_{4}+\mathrm{H}_{2} \mathrm{O} \\
\text { lead lead sulfuric } \\
\begin{array}{c}
2 \mathrm{PbSO}_{4} \\
\text { dioxide acid water sulfate oxide }
\end{array}
\end{gathered}
$$

The sponge lead and the lead dioxide are supported on grids made from lead alloys. The alloy materials may be a combination of antimony and arsenic, to increase grid strength and cell life, or calcium for safer operation. The positive and negative electrodes are usually separated by a microporous material. The plates of the cell are immersed in aqueous sulfuric acid electrolyte, which is contained in a plastic case. The cells are usually closed, 
except for ventilation requirements, and require the periodic addition of water. However, the recently developed "starved electrolyte" cell has an immobilized electrolyte that requires much less maintenance.

There are many manufacturers of lead acid batteries. Rather than discuss the cell design of each individual manufacturer, three categories of cell design will be described. These categories will include: 1) closed flooded electrolyte cel1,2) open flooded electrolyte ce11, and 3) starved electrolyte cell. Following the cell descriptions, some representative batteries that use the flooded electrolyte cell will be described.

\section{1 .1 .1 Closed Flooded Electrolyte Cell}

The closed flooded electrolyte cell could be considered to be the most traditional category for lead acid cell design. The generic cell has several flat plate electrodes per cell. The plates are made of lead alloy grids with a coating of the active material. Positive and negative plates are alternated with a porous separator in between. Ventilation is provided from the cover to allow the escape of hydrogen, arsine, and stibine. The electrolyte is usually stirred by airlift pumps to ensure even distribution. Cooling requirements are usually met with a water system. Maintenance requirements include adding water, tightening connections, cleaning cell vents and cover, checking temperature, and checking electrolyte composition.

5.1.1.2 Open Flooded Electrolyte Cell

The open flooded electrolyte cell uses the same materials as the more traditional closed version, but its configuration is substantially different. A typical open cell would be a large, uncovered tank containing dozens of plates. Evaporation is reduced by floating a layer of glass or plastic beads on the top of the electrolyte. This cell design is intended to be used for large, stationary installations. These open cells can be effectively cooled with air, but ventilation systems would still be needed to inhibit the deveiopment of explosive mixtures. The cooling and ventilation auxiliary systems costs would be saved, along with the cost of the cover. However, water 
addition is required more frequentiy. Because the cells are large, heavy, and difficult to stack, the land requirements for an open-cell battery are higher. The open cells are also more susceptible to contamination.

5.1.1.3 The Starved-Electrolyte Ce11

The starved electrolyte lead acid cell is currently in the developinental stage, and there is limited data available. These cells absorb the electrolyte with a highly porous separator, such as a combination of fiberglass and polyethylene. The cells can be operated in any position because the electrolyte is inmobilized. The separator has sufficient void space to dllow passage of oxygen from the positive to the negative electrode, where it reconbines with hydrogen to form water. The recombination theoretically eliminates the need to add water. The grid alloys contain no antimony, usually they are made of leadcalcium alloys instead. This eliminates the generation of toxic gases during the equalization charge cycle. Ventilation requirements are reduced when hydrogen is recombined and toxic gases are eliminated. The battery operates at a positive pressure, with a safety vent for release of gas if the rate of overcharge exceeds the rate of recombination of hydrogen and oxygen. External corrosion is eliminated, hecause acid mist is no longer released.

\subsubsection{Battery Design}

This section will qualitatively describe only those battery desiuns tiat use the closed flooded electrolyte cell. Battery descriptions were 1 inited i, this type of cell for the following reasons:

1. There is a wealth of information about batteries based on this cell type. Many manufacturers have published comprehensive descriptions of battery design, manufacturing procedures, installation, auxiliaries, and costs.

2. Conversely, there is not much information about batteries based on either open flooded or starved electrolyte cells.

3. Battery design incorporating flooded electrolyte cells could be modified for the starved cell by removing some auxiliary systems, such as 
the airlift pump, the ventilation exhaust, sloped floor, and acid resistant paint, and reducing or eliminating the maintenance requirements (Bechtel 1982).

\subsubsection{The ESB Batteries}

ESB has completed detailed design and cost studies on three different battery sizes: a $10 \mathrm{MW}-100 \mathrm{MWh}$ battery, a $20 \mathrm{MW}-60 \mathrm{MWh}$ battery, and a $20 \mathrm{MW}-$ 100 MWh battery (Ferrel1 1977, Ferrell et al. 1977). The 100-MWh batteries are based on two VLL 45 cell assemblies (one with high specific gravity electrolyte and one with low specific gravity electrolyte), and the 60 MWh system uses a similar VLL 43 cell. Bechtel also used one of the VLL 45 cell designs as the basis for their own cost estimates for a $6.2 \mathrm{MWh}(6200 \mathrm{kWh})$ energy storage system. Two representative battery sizes will be discussed in this section: the $20 \mathrm{MW}-100 \mathrm{MWh}$ system for utility storage, and the much smaller $6200 \mathrm{kWh}$ system intended for applications such as shopping centers.

The $20 \mathrm{MW}-100 \mathrm{MWh}$ ESB battery has an actual energy output of $120 \mathrm{MWh}$ at the beginning of its lifetime. It is constructed from 5484 VLL 45 (HSG) tubular positive cells with high specific gravity electrolyte. These cells are divided into six parallel strings, with each string containing 914 cells in series. The cells have only half an inch of space between them, except for safety aisles dividing the strings. This minimizes intercell connections and accessory systems, thereby reducing materials costs and increasing efficiency, but cell maintenance is more difficult. The cells are designed to meet the minimum output requirements (100 MWh) after a 2000 cycle ijfetime.

The auxiliary systems for this battery design include:

1. A cooling water system to remove the heat generated by reaction thermodynamics, resistive losses, and polarization.

2. An airlift stirrer to circulate the electrolyte and maintain uniform acid concentration.

3. Electrical monitors for cells and batteries.

4. Connections between cells, rows, and sections of the battery. Maintenance for this battery includes adding water to the cells to main- 
tain electrolyte levels and specific gravity, cleanup of leakages, and tightening intercelt connectors. Most of the water loss is expected to occur during the equalizing charge period. The battery is expected to require the addition of about 4.5 liters/month per cell of water. Intercell tightening would be needed shortiy after installation, and the connections are expected to remain tight for the lifetime of the battery. Leakage is expected to occur randomly.

The $775 \mathrm{~kW}$, $6200 \mathrm{kWh}$ battery was designed by Bechtel, based on information supplied by ESB about their VLL 45 LSG celt (Bechtel 1982). This battery is intended for smaller applications, such as energy storage for a shopping center. The battery has an eight-hour discharge period, a newly installed capacity of $7750 \mathrm{kWh}$, and an end-of-life capacity of $6210 \mathrm{kWh}$. It is made up of 340 tubular positive cells with low specific gravity electrolyte, arranged in a single series string. Spacing between the cells is one half inch, as with the $100 \mathrm{MWh}$ battery. The cells are arranged in two groups of four columns, and each column has 42 or 43 cells. There are aisles between the two groups and between the celis and the walls. The cell is expected to have a minimum lifetime of 2000 cycles, and a maximum lifetime of 2500 cycles. The lifetime is longer for this system, partly because the discharge period is longer, and partly because the electrolyte specific gravity is lower.

The auxiliary systems included in this design are:

1. A cooling water syster.

2. A ventilation system for the battery room.

3. Monitors for detecting fires, hydrogen levels, and toxic gas levels.

4. An air lift pump system for electrolyte stirring.

5. Connections between cells, plus DC busses, disconnects, circuit breakers, power cables, and lighting.

Maintenance for this system is essentially the same as for the larger 100 MWh ESB system. Water is added annually, and periodic checks for leakage and/or loose connections are expected to be needed. 


\subsubsection{The Westinghouse Battery}

Westinghouse has prepared detailed plans for a $10 \mathrm{MW}, 40 \mathrm{MWh}$ battery storage system, including a comprehensive discussion of the auxiliaries (Long 1977, Vaill 1977). This battery is based on their $\mathrm{kW} \mathrm{160-45} \mathrm{cell.} \mathrm{The} \mathrm{cell} \mathrm{has} \mathrm{a}$ nominal capacity of $3.2 \mathrm{KAh}$, or $6.2 \mathrm{kWh}$, at the beginning of its lifetime, when discharged over a 4-hour period. At the end of its lifetime, the cell has a capacity of $2.6 \mathrm{KAh}$, or $4.9 \mathrm{kWh}$ for a 4 -hour discharge period. The $40 \mathrm{MWh}$ battery contains 8085 of these cells, arranged in 21 parallel strings of 385 cells connected in series. The strings are further subdivided into 11 units; each unit contains 5 modules of 7 cells each. The module is designed to be the unit of assembly at the site, rather than the cell. Each module has a structural foam base and a cover, which includes water cooling coils, an automatic watering mechanism, and vent piugs. Each modu?e has a nominal capacity of 2600 Ah, or $34.6 \mathrm{kWh}$.

There have been extensive design studies made of the auxiliary systems needed to support the $\mathrm{kW} \mathrm{160-45} \mathrm{-} \mathrm{based} \mathrm{battery.} \mathrm{These} \mathrm{include} \mathrm{the} \mathrm{electrical}$ connections, the cooling water and automatic water addition systems, ventilation, monitoring and control, and power conversion.

A1l cables, wire ducts, and piping are routed underground. At the end of each string, there is an enclosure for the string contactor, fuse, and disconnect, which connects to the main bus work beneath the floor. The main bus connects underground to the converter.

The ventilation system uses a manifold for more efficient removal of gases and more flexible operation. Each cell in a module is connected through a flash arrestor to a module manifold. The module manifolds connect to the main underground ductwork at the end of each string. A fan is used to blow the gases out the exit stack.

Temperature control is provided with a water cooling system using an evaporative cooling tower and a colled tube heat exchanger immersed in the cell electrolyte. Each module has a series of intercell water tubes that supply the cooling water to the surfaces of individual cell walls. A thin layer of open 
cell foam is applied to the cell walls to aid uniform wetting. The evaporative cooling system is designed to reduce water requirements and capital costs.

Automatic water addition is expected to be required at weekly intervals. Deionized water is piped to distribution manifolds at each 5 module unit. The manifolds are overflow-controlled to provide a fixed head to the gravity feed fill valve in each cell. A water level detector triggers the necessary water addition.

Monitoring and control systems for fire protection, acid containment, cell ventilation, temperature control, battery charge/discharge control, and system maintenance are inciuded in the design. Different types of alarms, monitors, and controls were selected for all of these operations.

Maintenance is performed with a powered gantry crane used for overhead module handling. Disconnect fuses at the end of each unit provide safety for the personnel. Because an automatic watering system is used, maintenance requirements would be primarily module replacements, and repair of leakages or faulty connections.

\subsection{EVALUATION OF LEAD ACID COST ANALYSES}

This section evaluates the adequacy of previous cost data and cost analyses developed for conventional lead acid batteries. The structure of this section closely follows the list of cost characterizing information presented in Table 2.2. The adequacy of information is captured in the system completeness and level of detail associated with the cost analyses reviewed.

\subsubsection{System Descriptions}

Information on the batteries designed by ESB and Westinghouse should exist in sufficient detail to determine specific similarities and differences, if accurate cost comparisons are to be possible. The designs should include not only the battery itself, but should also describe the system in which the battery will be used so that the installation arrangements and auxiliary equipment can be compared. This section will discuss the battery system descriptions published by ESB and Westinghouse. 
ESB's report on their $20 \mathrm{MW}-100$ MWh battery includes comprehensive systen descriptions for everything except the tubular positive plates of the cells, the converter, and requirements for site installation. The description of the cells includes a listing of the quantity of lead, active materials, and electrolyte used to manufacture a cell; performance specifications at various discharge rates, and blueprints for the assembly of the cell. However, there are no descriptions of the configuration of the tubular positive plates, or of how they are produced.

The description of the auxiliary systems includes:

1. Oesigns and equipment lists for the cooling water system.

2. Equipment lists for the air lift stirrer.

3. Equipment lists for the electrical connections between cells, rows, and sections, and for the electrical monitoring of cells and batteries.

4. Calculations of the ventilation requirements based on the amount of each type of gas that would be generated by various battery operational modes.

The operating and maintenance requirements include instructions for performing daily charging, equalizing charging, and for operating the water cooling system. Recommendations for water addition include quantity and frequency requirements. There is a checklist for the inspection of cell connections, cell covers, and cooling systems. Safety precautions for working with acid electrolyte, electrical charge, and flammable and toxic gases are also included.

The Bechtel design of a $6200 \mathrm{kWh}$ battery based on ESB cells does not include as much information about the cells or the battery system, but does include information about installation requirements, except for power conversion. Bechtel's battery layout, performance specifications, and electrical connections are briefly described. The various auxiliary systems are essentially the same as the system described by ESB. The Bechtel report, when combined with the information already published by ESB, presents a well-defined battery system. 
The Westinghouse $40 \mathrm{MWh}$ battery, based on their $\mathrm{kW} \mathrm{160-45} \mathrm{cell,} \mathrm{also} \mathrm{has}$ comprehensive system descriptions. Cell design information includes a diagram showing its configuration and dimensions, a flow chart describing its assembly, and a diagram of a seven-cell module. The description of the battery includes the layout diagrams, dimensions, and electrical connections, along with diagrams and designs for auxiliaries such as automatic watering, cooling, ventilation, monitoring, maintenance, safety systems, and power conversion. Instructions are given on how to charge and discharge the battery, how to maintain adequate ventilation, and how to repair or replace faulty modules.

The Westinghouse design for a lead acid battery also includes information about a state-of-the-art converter that a utility would need to transfer the stored energy. The technical information presented is adequate for accurate cost comparisons to be made between battery systems. The information is consistent, complete, and has the detail necessary to back the design decisions.

\subsubsection{Performance Specifications}

The performance specifications define the functions of the battery systems and include ratings of capacity, output, efficiencies, loading, and charge/ discharge time. Performance specifications are needed, along with design specifications, to ensure cost comparability between different battery systems. The performance specifications are listed in Table 5.1 for the $100 \mathrm{MWh}$ ESB Battery, the $40 \mathrm{MWh}$ Westinghouse battery, and the $6200 \mathrm{kWhr}$ Bechtel battery based on ESB cells. The performance specifications for the three designs for lead acid batteries evaluated in this section are adequate for accurate cost comparisons.

\subsubsection{Manufacturing Costs}

Manufacturing cost estimates reviewed for lead acid batteries are similar to zinc bromine and sodium sulfur in that the level of detail and completeness varied significantly among the battery developers. The principal difference between the manufacturing cost analyses for lead acid and the other two technologies is the greater detail provided by two of the lead acid developers. Each of the reports reviewed are discussed below. 
TABLE 5.1. Performance Specifications for Lead Acid Batteries

\begin{tabular}{|c|c|c|c|}
\hline Specification & ESB & Westinghouse & Bechte! \\
\hline Nominal Energy Capacity & $100 \mathrm{MWh}$ & $40 \mathrm{MWh}$ & $6.2 \mathrm{MWh}$ \\
\hline Average Discharge Voltage & $1700 \mathrm{~V}$ & $162 \mathrm{~V}$ & $700 \mathrm{~V}$ \\
\hline Charge Voltage & $2150 \mathrm{~V}$ & $1700 v^{(a)}$ & $800 v^{(a)}$ \\
\hline Equalization Voltage & $2400 v$ & $1900 V^{(a)}$ & $900 V^{(a)}$ \\
\hline Discharge Current & $14 \mathrm{kA}$ & $6.5 \mathrm{kA}^{(\mathrm{a})}$ & -- \\
\hline Power Rating & $20 \mathrm{MW}$ & $10 \mathrm{MW}$ & $0.8 \mathrm{MN}$ \\
\hline Discharge Time & $5 \mathrm{~h}$ & $4 \mathrm{~h}$ & $8 \mathrm{~h}$ \\
\hline Charge Time & $9 \mathrm{~h}$ & $10 \mathrm{~h}$ & $9 \mathrm{~h}$ \\
\hline Energy/Area & $2.6 \mathrm{kWh} / \mathrm{ft}^{2}$ & $1.7 \mathrm{kWh} / \mathrm{ft}^{2}$ & $2.1 \mathrm{kwh} / \mathrm{ft}^{2}$ \\
\hline Energy Efficiency & $85 \%$ & $76 \%$ & $82 \%$ \\
\hline Expected Lifetime & 2000 cycles & 1750 cycles & 2500 cycles \\
\hline
\end{tabular}

(a) Calculated from available data for individual cells

Westinghouse completed manufacturing cost estimates for both "state-ofthe-art" (Long 1977) and "advanced technology" (Pittman 1977) batteries. Both estimates included a comprehensive bill of materials. Equipment cost, labor requirements, and factory floor space were all itemized per unit operation. overhead costs were also estimated on an itemized basis. The only shortcomings found were the lack of a process flow diagram in Pittman (1977) and the need for greater explanation of how profit and taxes were incorporated into the factory selling price.

Arother detailed manufacturing cost analys is was completed by ESB, Inc., (Ferrell 1977) for their battery. The level of detail and completeness is similar to the Westinghouse studies described above. Materials, equipment, floor space, and manpower requirements are all itemized, the latter three per unit operation. ESB also includes a process flow diagram. 0verhead costs are not well defined, however, and the inclusion of profit and taxes in the selling price could be explained better. Neither Westinghouse nor ESB used the subsequently published A. D. Little guidelines, which would remove the uncertainty surrounding the estimates of overheads, profit, and taxes. 
Manufacturing cost estimates for three other lead acid battery developers, Gould, Globe Union, and C\&D, were not as detailed as for Westinghouse or ESB. Only summary estimates were presented in papers presented at the Second Workshop on Lead Acid Batteries for Utility Applications. No detailed design report was found for C\&D. A design report prepared by Globe Union (Weinlein 1977) did not include any cost information. Gould has more recently completed a comparison of several advanced storage batteries in residential, commercial, and utility applications (Ramsay 1982). The Ramsay report identifies the inputs to the A. D. Little manufacturing cost model for both low maintenance and maintenance-free lead acid batteries, but does not give any backup for how these inputs were estimated. Lead acid battery manufactured cost estimates are summarized in Table 5.2. Supporting details for the manufacturing cost estimates are presented in Appendix $C$.

\subsubsection{Installed System Costs}

Much more has been done to define balance-of-plant (BOP) and installed system costs for lead acid batteries than for either zinc bromine or sodium sulfur batteries. The most detailed work in this area has been completed by Westinghouse and Bechtel.

TABLE 5.2. Manufactured Cost Estimates for Lead Acid Batteries

\begin{tabular}{|c|c|c|c|}
\hline \multicolumn{2}{|c|}{ Source } & Battery Design & $1984 \$ / \mathrm{kWh}$ \\
\hline Boden & 1977 & $C \& D$ & 82 \\
\hline Ferrell & 1977 & ESB & $77-88$ \\
\hline Towle & 1977 & Globe-Union & 97 \\
\hline Hel Iman & 1977 & Gould & 86 \\
\hline Ramsay & 1982 & Gould - Low Maintenance & 116 \\
\hline Rams ay & 1982 & Gould - Maintenance Free & 126 \\
\hline Long & 1977 & Westinghouse - State of the Art & 81 \\
\hline Pittman & 1977 & Westinghouse - Advanced & 70 \\
\hline
\end{tabular}


Westinghouse (1976) completed a detailed definition of BOP requirements and a conceptual design and cost estimate for lead acid battery systems. Auxiliary components specifically addressed by Westinghouse are identified in Table 5.3. Westinghouse developed a conceptual design and cost estimate for a baseline $40 \mathrm{MWh}, 1620 \mathrm{VDC}$ system and then evaluated the cost/performance tradeoffs under different assumptions for system voltage, cell reliability, level of monitoring, type of thermal management system, power rating, and larger cells. Costs were itemized per individual equipment item, and included an estimate for the converter. The estimates did not identity the breakdown between equipment, labor, and materials, however, or discuss the unit labor and material rates that went into the estimates.

Bechtel has completed several studies (Stolte 1977; Stolte 1982; Bechtel 1982) that address balance-of-plant costs for lead acid and other batteries. The 1977 study developed designs and costs for ten different battery systems built around the cells of the five lead acid battery developers (identified in Tabie 5.2). Costs were estimated for a complete system, including converters, thermal management, ventilation, controls, site, and building costs. Costs were broken down into direct and indirect field costs, engineering, and contingency. The 1982 report by Stolte developed BOP costs as part of a customerside-of-the-meter assessment. Balance-of-plant components included battery

\section{TABLE 5.3. Westinghouse BOP Components}

\begin{tabular}{ll}
\multicolumn{1}{c}{ Operational } & Safety and Protection \\
\hline Ventilation & Electrical Protection \\
Temperature Control & Acid Containment \\
Water Addition & Fire Equipment \\
Monitoring and Control & Sydrogen Detection \\
Charge/Discharge Control & Arsine Detection \\
Bus Work & \\
Maintenance Requirements & \\
Layout & \\
Enclosure &
\end{tabular}


and power conditioning structures, control and monitoring, stibine and arsine detectors, direct current wiring and switchgear, fire protection, and makeup water system. Converters were specifically characterized and costed separately. Power conditioning (converter) costs were estimated as a function of rated power for both state-of-the-art and advanced designs. Balance-of-plant costs were estimated as a function of system capacity and duration deviation. These cost estimates were then used in a parametric investigation of customerside-of-the-meter applications. The other Bechtel report (Bechtel 1982) estimated installed costs for conventional and sealed lead acid batteries in photovoltaic applications. Detailed BOP cost estimates were developed for eleven different battery/application combinations. The basis for BOP cost estimates is explained explicitly and costs are broken down into direct, indirect, and contingency components. No converter costs were included, however.

Other estimates of lead acid BOP costs include those by Ferrell (1977), Ramsay (1982) and Birk (1977). Each of these are of less detail and/or based on estimates developed by Westinghouse and Bechtel. Lead acid battery Bop and converter costs estimated by Westinghouse (1976) and Bechtel (Stolte 1977) have been inflated to 1984 dollars and are summarized in Table 5.4. Supporting details for the installed cost estimates are presented in Appendix $C$.

\subsubsection{Life-Cycle Costs}

The life-cycle costs of lead acid battery systems have been well defined compared to zinc bromine and sodium sulfur batteries. Several reports were reviewed that included estimates of 0\&M, salvage and other life-cycle cost components. Bechtel (Bechtel 1982, Stolte 1982) and Gould (Ramsay 1982) have completed the most detailed analyses of life-cycle costs. Each of these reports is discussed briefly below.

TABLE 5.4. Lead Acid BOP Costs

$\begin{array}{lcc}\frac{\text { Source }}{\text { Stolte }(1977)} & \frac{\text { Energy Related Costs }}{47-94 \$ / \mathrm{kWh}} & \frac{\text { Power Related (Conyerter) Costs }}{127-139 \$ / \mathrm{kW} \text { A } 20 \mathrm{MW}} \\ \text { Westinghouse (1976) } & \$ 53 / \mathrm{kWh} & \$ 131 / \mathrm{kW} \mathrm{A} 10 \mathrm{MW}\end{array}$


Bechtel has defined O\&M and other life-cycle cost components for lead acid batteries. Bechtel estimates 0\&M, salvage, battery replacement, and auxiliary power costs for state-of-the-art lead acid batteries in Stolte (1982). Costs were estimated based on consultation with battery manufacturers and Bechtel's engineering judgment. Expectations of maintenance requirements and net salvage credit varied widely among manufacturers, which points out the need to verify estimates with field tests. In a parallel study Bechtel (1982) estimated installed and life-cycle costs for conventional and sealed lead acid batteries in several different photovoltaic applications. Both of the Bechtel reports consider all the principal life-cycle cost components and provide a description of how the costs were estimated.

Ramsay (1982) has also estimated life-cycle costs for low maintenance and maintenance-free lead acid batteries in photovoltaic applications. Estimates were developed for battery replacement, $0 \& M$ costs, and salvage credit. Auxiliary power requirements and efficiency losses were not characterized. Battery cell replacement was based on the continuous (rather than periodic) replacement of cells. This would enhance system reliability, but increases this aspect of life-cycle costs. Estimates for a $2000 \mathrm{kWh}$ system are shown in Table 5.5 . Costs have been adjusted to 1984 dollars, but otherwise have not been normalized to common assumptions. Supporting details for the life-cycle cost estimates are presented in Appendix $C$.

TABLE 5.5. Non-Normalized Life-Cycle Cost Estimates for Lead Acid Batteries

\begin{tabular}{|c|c|c|}
\hline Source & Battery Type & $\$ 1984 / \mathrm{kWh}$ \\
\hline Ramsay (1982) & "low maintenance" & $586-625$ \\
\hline Ramsay (1982) & "maintenance-free" & $344-371$ \\
\hline Bechtel (1982) & "conventional" & $447-761$ \\
\hline Bechtel (1982) & "sealed" & $477-800$ \\
\hline
\end{tabular}




\subsection{OBSERVATIONS AND RECOMMENDATIONS}

In general, cost analyses for mature lead acid batteries have been more numerous, more complete, and have greater detail than for either zinc bromine or sodium sulfur batteries. Several cost analyses completed for lead acid batteries could, with minor modifications, serve as examples of expected levels of detail and completeness for other batteries. The quality of the economic anaiyses combined with greater commercial experience has created a lower level of uncertainty in costs for lead acid battery systems.

The lack of maturity in zinc bromine and sodium sulfur cost analyses compared to lead acid can be partly attributed to the differences in design maturity. The level of design detail available provides an upper limit to the level of cost detail possible. Still, improvements could be made even at the current level of design maturity. Problems currently facing zinc bromine and sodium sulfur cost analyses are presented and briefly discussed below:

Cost Information is Fragmented. No single report addresses each of the six major categories of cost characterizing information. Rapidly changing designs make it difficult to trace costs presented in one report to design information presented in another report.

Completeness of Estimates Varies Significantly. Incomplete estimates inevitably lead to underestimated costs. Differences in the level of completeness also makes direct comparison of cost estimates impossible.

Many Estimates Lack Supporting Details. Lack of detail makes an independent reproduction of the estimate impossible, thus lowering believability. For example, descriptions of manufacturing operations, floor space requirements, and equipment were often 1 imited, if they existed at all.

Very Few Installed System or Life-Cycle Cost Estimates. Estimates of installed system and life-cycle costs were limited to three sources for zinc bromine and two sources for sodium sulfur.

The above comments apply to both zinc bromine and sodium sulfur cost analyses. Table 6.1 lists some additional observations that identify differences in the status of zinc bromine and sodium sulfur cost analyses. 


\section{TABLE 6.1. Zinc Bromine/Sodium Sulfur Status Comparison}

1. Detailed sodium sulfur manufacturing cost studies are several years old.

2. Detailed zinc bromine manufacturing cost studies are fairly recent.

3. Design and material specification detail is generally less for sodium sulfur than for zinc bromine.

4. Performance specification detail is generally greater for sodium sulfur than zinc bromine.

The following observations apply to all battery systems. Converter costs were found to vary widely with assumptions regarding power level, design, and production volume. Converters for large battery systems are currently in their own developmental phase and suffer from cost uncertainty that is comparable to the batteries themselves. Finally, it's important to remember that the technical feasibility, the probability a battery will work as advertised, may be significantly different for two batteries that are estimated to have similar initial and operating costs. Two systems must provide a similar service in order for cost comparisons to be meaningful.

In view of the observations summarized above, the following recommendations are offered as a means to improve battery cost analyses:

1. Develop standard guidelines which establish the system components to be included, the appropriate level of detail in description, and ground rules and assumptions for estimating manufacturing, installed system, and iife-cycle costs. The implementation of guidelines would serve to standardize the economic analysis procedure and focus on cost differences attributable to differences in battery type or design.

2. Spend more effort characterizing installed system and life-cycle costs. Balance-of-plant, battery replacement, and 0\&M costs are just as important as manufacturing costs to the total battery system cost. Additional balance-of-plant and life-cycle cost studies are needed to develop a balanced set of cost characterizing information. 
3. Complete cost analyses in more detail and more frequently. More frequent cost analyses will minimize the problem of cost analyses becoming outdated by changes in technology.

Each of the recommendations cited above represents a part of an overall plan to enhance the quality of battery cost analysis. The availability of quality cost data is seen as a first step in this plan. Consistent cost analyses completed for the entire battery system will lay the groundwork for the development of cost goals, R\&D plans, market assessments, and cost/performance tradeoffs. 
,

.

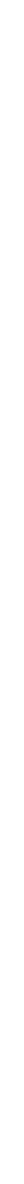


APPENDIX A

ZINC BROMINE COST DETAILS 
The following pages present cost estimating details extracted from the sources reviewed for this study. The tables have been reproduced to match the figures and notes presented in the original sources except for some minor modification to the format or style. Additional clarifying comments, if any, are designated as PNL Notes.

The data provide an indication of the completeness and Tevel of detail found among the various estimates and also serve as a rudimentary data base of battery cost information. The supporting details presented in this appendix correspond to the cost estimates referenced in Tables $3.2,3.3$, and 3.4 . 
TABLE A.1. Bechte1 (1982) Manufacturing Cost Estimate

Factory Price Estimate - Zinc-Bromine Battery (Gould)

\begin{tabular}{|c|c|c|}
\hline & \multicolumn{2}{|c|}{$1980 \$ / \mathrm{kWh}$} \\
\hline & Low & $\mathrm{High}$ \\
\hline $\begin{array}{l}\text { Labor (Direct }+150 \% \text { 0verhead) } \\
\text { Materials (Materials }+10 \% \text { Overhead) } \\
\text { Energy } \\
\text { Depreciation } \\
\text { Rent }\end{array}$ & $\begin{array}{l}-- \\
68.10 \\
-- \\
-- \\
-\end{array}$ & $\begin{array}{l}-- \\
83.00 \\
-- \\
-- \\
-\end{array}$ \\
\hline Factory Cost $(a)$ & 68.10 & $\overline{83.00}$ \\
\hline $\begin{array}{l}\text { After Tax R0I (15\%) } \\
\text { Taxes (15\% of Investment) } \\
\text { Marketing, Warranty, and Miscellaneous }\end{array}$ & $\begin{array}{l}3.06 \\
3.06 \\
5.00\end{array}$ & $\begin{array}{l}3.74 \\
3.74 \\
5.00 \\
\end{array}$ \\
\hline FOB Factory Price ${ }^{(a)}$ & 79.22 & 95.48 \\
\hline \multicolumn{3}{|l|}{ Manufacturing Plant Assumptions (a) } \\
\hline & Low & High \\
\hline $\begin{array}{l}\text { Equipment (Including } 25 \% \text { Installation) } \\
\text { Working Capital ( } 30 \% \text { of Factory Cost) }\end{array}$ & $51, \overline{075}$ & $62, \overline{250}$ \\
\hline Total PTant Investment & 51,075 & 62,250 \\
\hline $\begin{array}{l}\text { Unit Capacity, kWh } \\
\text { Production Volume, MWh/ } \mathrm{Xr}^{r} \\
\text { Factory Floor Space, } \mathrm{ft}^{2}\end{array}$ & & \\
\hline
\end{tabular}

(a) Estimate does not include costs for labor, and manufacturing facility and equipment. Preliminary results from a more recent study (by Gould), which includes labor and manufacturing facility costs, indicate a FOB price of $\$ 96 / \mathrm{kWh}$ to $\$ 138 / \mathrm{kWh}$. These more recent numbers were used in the installed cost estimate presented in later sections of this report.

PNL Note: FOB prices of $\$ 96-138 / \mathrm{kWh}$ (1980 \$) were inflated to $\$ 120-172 / \mathrm{kWh}(1984 \$)$. 
TABLE A.2. Bechtel (1982) Balance of System Cost Estimate

BOS Installer Cost Estimate

Battery: Zinc-Bromine (Gould)

Application: Shopping Center

\begin{tabular}{|c|c|c|c|c|c|c|c|}
\hline & & & osts (1980 & \$) & Cost & istri & ution \\
\hline System/Component & Hours & Labor & Material & Subtotal & 5 & $\$ 7 \mathrm{~kW}$ & $\$ / \mathrm{kWh}$ \\
\hline Battery & & & & & & & \\
\hline Shipping (500 miles) & $-\overline{-}$ & $-\overline{0}$ & -- & 26,640 & -- & -- & 4.27 \\
\hline Installation & 1,638 & 29,480 & -- & 29,480 & -- & -- & 4.72 \\
\hline Other & -- & $\cdots$ & 3,120 & 3,120 & $\rightarrow$ & -- & 0.50 \\
\hline Building & & & & & & & \\
\hline Land & -- & -- & -- & 1,800 & -- & -- & 0.29 \\
\hline Building & -- & -- & -- & 126,000 & -- & -- & 20.19 \\
\hline Structural & 380 & 6,840 & 3,200 & 10,040 & 2,680 & -- & 1.18 \\
\hline Thermal Management & & & & & & & \\
\hline Heat Rejection & 50 & 900 & $25, \mathrm{D} 00$ & 25,900 & -- & -- & 4.15 \\
\hline Piping, Pumps, Valves & 307 & 5,530 & 14,960 & 20,490 & -- & -- & 3.28 \\
\hline Other & 56 & 1,010 & 3,280 & 4,290 & -- & -- & 0.69 \\
\hline Instrumentation & & & & & & & \\
\hline Fire Detection & 10 & 180 & 130 & 310 & 310 & -- & -- \\
\hline Electrical & & & & & & & \\
\hline DC Wiring & 600 & 10,800 & 99,000 & 109,800 & -- & -- & 17.60 \\
\hline DC, Equipment & 32 & 580 & 10,660 & 11,240 & -- & -- & 1.80 \\
\hline AC Wiring & 618 & 11,120 & 4,980 & 16,100 & - & -- & 2.58 \\
\hline AC Panel Requirements & 24 & 430 & 600 & 1,030 & $-\rightarrow$ & -- & 0.17 \\
\hline Lighting & 191 & 3,440 & 1,850 & 5,290 & -- & $\rightarrow$ & 0.85 \\
\hline 0ther & & 110 & $\mathbf{7 5 0}$ & 860 & $=$ & $=$ & 0.14 \\
\hline Subtotals & 3,912 & 70,420 & 167,530 & 392,390 & 2,990 & 0 & 62.41 \\
\hline & Total & $\begin{array}{l}\text { birect } \\
\text { direct }\end{array}$ & $\begin{array}{l}\text { ald Cost } \\
\text { old Cost }\end{array}$ & $\begin{array}{r}392,390 \\
35,210\end{array}$ & $\begin{array}{r}2,990 \\
270\end{array}$ & $\begin{array}{l}0 \\
0\end{array}$ & $\begin{array}{r}62.40 \\
5.60\end{array}$ \\
\hline & & BOS & ield cost & 427,600 & 3,260 & 0 & 68.00 \\
\hline
\end{tabular}


TARLE A.3. Bechtel (1982) Installed System Cost Estimate Total Installed Costs (1980 \$)

Battery: Zinc-Bromine (fould)

\begin{tabular}{|c|c|c|c|c|}
\hline \multirow[b]{2}{*}{ Item } & \multicolumn{4}{|c|}{ Low Estimate } \\
\hline & $\begin{array}{c}\text { Total } \\
\text { Cost } \\
\$ \\
\end{array}$ & $\begin{array}{l}\text { Cost } \\
\$\end{array}$ & $\begin{array}{c}\text { Distribut } \\
\$ / \mathrm{kW}\end{array}$ & $\begin{array}{l}\text { ion } \\
\$ / \mathrm{kWh}\end{array}$ \\
\hline Rattery, $F O B(a)$ & 599,040 & 0 & 0 & 96 \\
\hline BOS, Field Cost(b) & 256,560 & $.1,960$ & $\underline{0}$ & 41 \\
\hline Total Field Cost & 855,600 & 1,960 & 0 & 137 \\
\hline Engineering Costs (15\%) & 128,340 & 290 & $\underline{0}$ & 21 \\
\hline Subtotal & 983,940 & 2,250 & 0 & 158 \\
\hline Contingency $(20 \%)$ & 196,790 & 450 & $\underline{0}$ & 32 \\
\hline Total Installed Cost & $1,180,730$ & 2,700 & 0 & 190 \\
\hline
\end{tabular}

Application: Shopping Center

\begin{tabular}{|c|c|c|c|}
\hline \multirow{2}{*}{$\begin{array}{c}\text { Total } \\
\text { Cost } \\
\$ \\
\end{array}$} & \multicolumn{3}{|c|}{ Cost Distribution } \\
\hline & $\$$ & $\$ / \mathrm{kW}$ & $\$ / \mathrm{kWh}$ \\
\hline 861,120 & 0 & 0 & 138 \\
\hline 513,120 & 3,910 & $\underline{0}$ & 82 \\
\hline $1,374,240$ & 3,910 & 0 & 220 \\
\hline 206,140 & 590 & $\underline{0}$ & 33 \\
\hline $1,580,380$ & 4,500 & 0 & 253 \\
\hline 316,080 & 900 & $\underline{0}$ & 51 \\
\hline $1,896,460$ & 5,400 & 0 & 304 \\
\hline
\end{tabular}

(a) From Table A.1

(b) From Table A.2. High $=1 . ? \times$ Field rost; Low $=0.6 \times$ Field Cost .

PNL Note: Installed system costs of $\$ 190-304 / \mathrm{kWh}(1980 \$)$ were inflated to $\$ 237-379 / \mathrm{kWh}(1984 \$)$. 
TABLE A.4. Bechtel (1982) Frequent Maintenance for the Gould Zinc-Bromine Battery in the Shopping Center

\begin{tabular}{|c|c|c|c|c|c|}
\hline Activity & Frequency & $\begin{array}{l}\text { Labor, } \\
\text { Manhours } \\
\text { Per Event } \\
\end{array}$ & $\begin{array}{c}\text { Material } \\
\$ \\
\text { Per Event } \\
\end{array}$ & $\begin{array}{c}\text { Annu } \\
\text { Low } \\
\$\end{array}$ & $\begin{array}{c}\text { Cost } \\
\text { High } \\
\$\end{array}$ \\
\hline $\begin{array}{l}\text { Battery } \\
\text { Maintenance }\end{array}$ & Annual & 20 & -- & 220 & 308 \\
\hline $\begin{array}{l}\text { Cooling } \\
\text { System } \\
\text { Maintenance }\end{array}$ & Annua? & 9 & 200 & 299 & 418 \\
\hline
\end{tabular}


TABLE A.5. Bechtel (1982) Infrequent Maintenance for the Gould Zinc-Bromine Battery in the Shopping Center

\begin{tabular}{|c|c|c|c|c|c|}
\hline \multirow[b]{2}{*}{ Activity } & \multirow[b]{2}{*}{$\begin{array}{l}\text { Frequency } \\
\text { Years }\end{array}$} & \multirow{2}{*}{$\begin{array}{r}\text { Labor, } \\
\text { Manhours } \\
\text { Per Event } \\
\end{array}$} & \multirow{2}{*}{$\begin{array}{c}\text { Material } \\
\$ \\
\text { Per Event } \\
\end{array}$} & \multicolumn{2}{|c|}{ Annual Cost } \\
\hline & & & & $\begin{array}{c}\text { Low } \\
\$\end{array}$ & $\begin{array}{c}\text { High } \\
\$\end{array}$ \\
\hline Coolant Pump & 8 & 25 & 1,500 & 2,300 & 3,220 \\
\hline $\begin{array}{l}\text { Refrigerator } \\
\text { System }\end{array}$ & 12 & 30 & 9,000 & 9,960 & 13,944 \\
\hline
\end{tabular}


TABLE A.6. Bechte1 (1982) Low Life-Cycle Cost Estimate

Battery Type: Zinc-Bromine (Gould)

Application Type: Shopping Center

Low Est imate Input Parameters

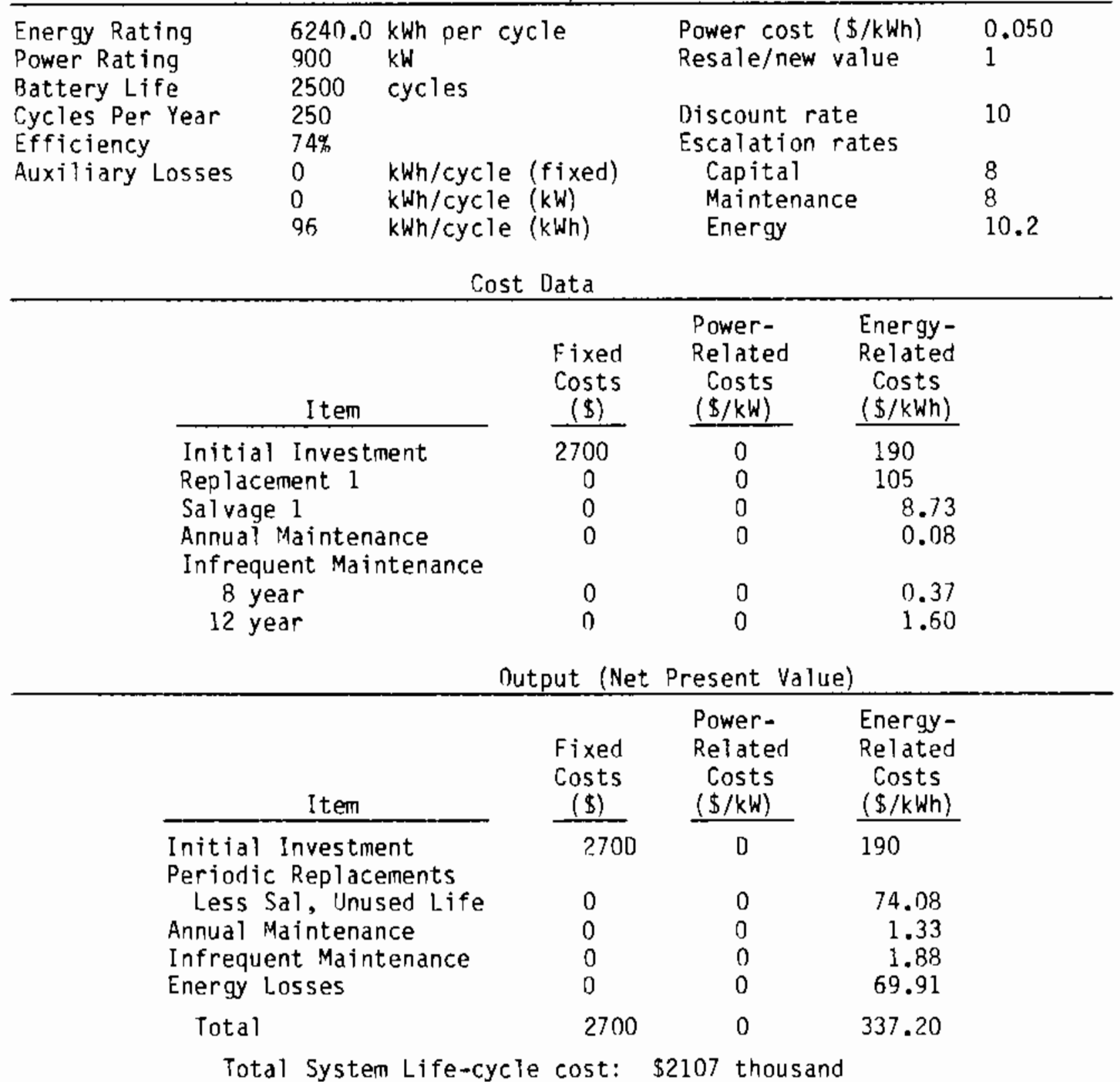

PNL Note: Life-cycle cost of $\$ 337.20 / \mathrm{kWh}$ (1980 \$) was inflated to $\$ 420 / \mathrm{kWh}$ (1984 \$). 
TABLE A.7. Bechtel (1982) Life-Cycle Cost Analysis (1980 \$)

Battery Type: Zinc-Bromine (Gould)

Application Type: Shopping Center

High Estimate Input Parameters

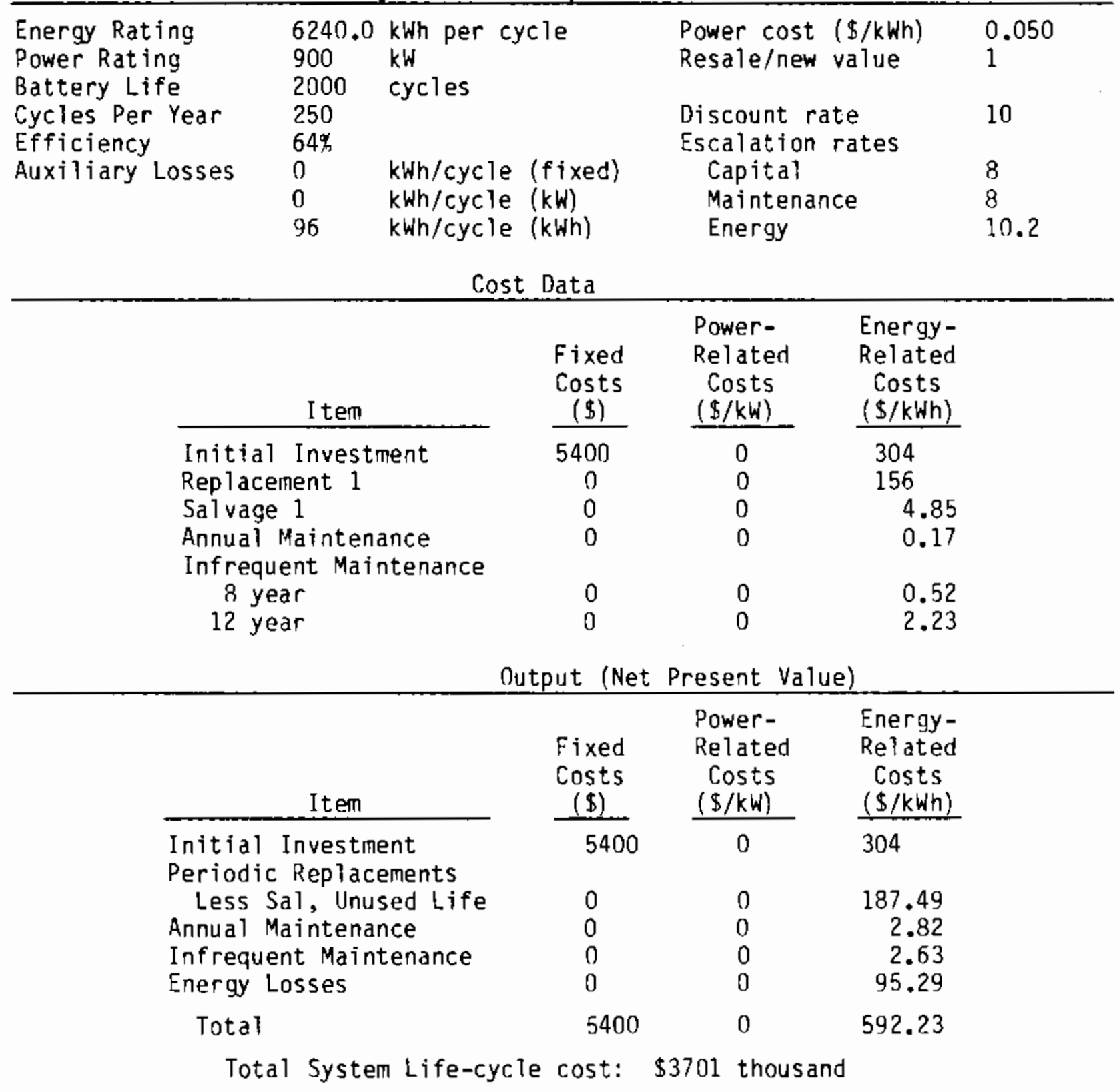

PNL Note: Life-cycle cost of $\$ 592.23 / \mathrm{kWh}(1980 \$$ ) was inflated to $\$ 738 / \mathrm{kWh}$ $(1984 \$)$. 
TABLE A.8. Bechtel (1982) Manufacturing Cost Estimate

Factory Price Estimate--Zinc-Bromine Battery (Exxon)

Labor (Direct $+150 \%$ Overhead)

$1980 \$ / k$ Wh

Materials (Materials + $10 \%$ Overhead)

Energy

Depreciation

Rent

Factory Cost $(b)$

\begin{tabular}{|c|c|}
\hline Low & $\operatorname{High}(\mathrm{a})$ \\
\hline $\begin{array}{r}3.52 \\
26.65\end{array}$ & $\begin{array}{r}7.04 \\
39.98\end{array}$ \\
\hline $\begin{array}{l}-- \\
0.50 \\
0.20\end{array}$ & $\begin{array}{l}-- \\
0.50 \\
0.20\end{array}$ \\
\hline 30.87 & 47.72 \\
\hline $\begin{array}{l}2.14 \\
2.14 \\
5.00 \\
\end{array}$ & $\begin{array}{l}2.90 \\
2.90 \\
5.00 \\
\end{array}$ \\
\hline 40.15 & 58.52 \\
\hline
\end{tabular}

Manufacturing Plant Assumptions

After Tax ROI (15\%)

Taxes (15\% of Investment)

Marketing, Warranty, and Miscellaneous

FOB Factory Price $(c)$

\begin{tabular}{|c|c|}
\hline 1980 & $\times 10^{3}$ \\
\hline Low & High \\
\hline $\begin{array}{l}12,500 \\
23,153\end{array}$ & $\begin{array}{l}12,500 \\
35,790\end{array}$ \\
\hline 35,653 & 48,290 \\
\hline
\end{tabular}

Unit Capacity, kWh

Production Volume, Mwh/yr

2,500

Factory Floor Space, $\mathrm{ft}^{2}$

100,000

Notes:

(a) The high estimate presented here is based on projected uncertainties in labor and materials costs. Other components of the estimate were not adjusted.

(b) Factor cost included no contribution from energy costs since these were projected to be less than $5 \%$ of materials costs.

(c) The factory price does not include a required heat exchanger nor intermodule electrical connectors. 
TABLE A.9. Bechtel (1982) Adjusted Manufacturing Cost Estimate Exxon Zinc-Bromine Battery Adjusted Factory Prices

\begin{tabular}{|c|c|c|c|}
\hline \multirow{2}{*}{$\begin{array}{l}\text { Application } \\
\text { Type }\end{array}$} & \multirow{2}{*}{$\begin{array}{c}\text { System Capacity } \\
\mathrm{kWh} \\
\end{array}$} & \multicolumn{2}{|c|}{$\begin{array}{c}\text { Adjusted Factory Price, (a) } \\
\text { FOB, } 1980 \mathrm{\$} / \mathrm{kWh}\end{array}$} \\
\hline & & Low & High \\
\hline Baseline Mordule & 20 & 40 & 59 \\
\hline Multiple Residence & 640 & 35 & 54 \\
\hline Remote Residence ${ }^{(b)}$ & 160 & $41)$ & 59 \\
\hline Single Residence & 16 & 56 & 80 \\
\hline
\end{tabular}

Notes: (a) Baseline battery price plus applicable credits or less applicable penalties.

(b) The remote residence uses the baseline module without change.

PNL Note: The multiple residence prices of $\$ 35-54 / \mathrm{kWh}$ (1980\$) were inflated to $\$ 44-67 / \mathrm{kWh}$ (1984 \$). 
TABLE A.10. Bechtel (1982) Balance of System Cost Estimate

BOS Installed Cost Estimate

Battery: Zinc-Bromine (Exxon) Application: Multiple Residence

\begin{tabular}{|c|c|c|c|c|c|c|c|}
\hline & & & osts $(1980$ & & Cost & jistr & \\
\hline System/Component & Hours & Labor & Material & Subtotal & $\$$ & $\$ / \mathrm{kW}$ & $\$ / \mathrm{kWh}$ \\
\hline Battery & & & & & & & \\
\hline Shipping (500 miles) & -- & -- & -- & 1,020 & - & -- & 1.59 \\
\hline Installation & 76 & 1,370 & $-\cdot$ & 1,370 & -- & -- & 2.14 \\
\hline Other & -- & -- & 320 & 320 & -- & -- & 0.50 \\
\hline Building & & & & & & & \\
\hline Building & -- & -- & -- & 15,000 & -- & -- & 23.44 \\
\hline Structural & 249 & 4,480 & 3,160 & 7,640 & 2,680 & -- & 7.75 \\
\hline Thermal Management & & & & & & & \\
\hline Heat Rejection & 32 & 580 & 2,320 & 2,900 & -- & -- & 4.53 \\
\hline Piping, Pumps, Valves & 13 & 230 & 380 & 610 & -- & - & 0.95 \\
\hline Instrumentation & & & & & & & \\
\hline Fire Detection & 10 & 180 & 130 & 310 & 310 & -- & -- \\
\hline Other & 15 & 270 & 230 & 500 & 500 & -- & -- \\
\hline Electrical & & & & & & & \\
\hline DC Wiring & 10 & 180 & 260 & 440 & -- & -- & 0.59 \\
\hline OC Equipment & 18 & 320 & 1,280 & 1,600 & $-\infty$ & -- & 2.50 \\
\hline AC Wiring & 76 & 1,370 & 640 & 2,010 & -- & -- & 3.14 \\
\hline AC Panel Requirements & 14 & 250 & 340 & 590 & -- & $\rightarrow$ & 0.92 \\
\hline Lighting & 59 & 1,060 & 620 & 1,680 & -- & -- & 2.63 \\
\hline 0 ther & 1 & 20 & 60 & 80 & $=$ & $=$ & 0.13 \\
\hline Subtotals & 573 & 10,310 & 9,740 & 36,070 & 3,490 & 0 & 50.93 \\
\hline & Total & Direct & ield Cost & 36,070 & 3,490 & 0 & 50.90 \\
\hline & & $\begin{array}{r}\text { direct } \\
\text { BOS }\end{array}$ & $\begin{array}{l}\text { ield Cost } \\
\text { ield Cost }\end{array}$ & $\begin{array}{r}5,670 \\
41,740\end{array}$ & $\begin{array}{r}550 \\
4,040\end{array}$ & $\begin{array}{l}0 \\
0\end{array}$ & $\begin{array}{r}8.00 \\
58.90\end{array}$ \\
\hline
\end{tabular}


TABLE A.11. Bechtel (1982) Installed System Cost Estimate

Total Installed Costs

(1980 \$)

Battery: Zinc-Rromine (Exxon)

\begin{tabular}{|c|c|c|c|}
\hline \multicolumn{4}{|c|}{ Low Fstimate } \\
\hline $\begin{array}{c}\text { Cost } \\
\$\end{array}$ & $\frac{\operatorname{Cost}}{\$}$ & $\begin{array}{c}\text { Distribut } \\
\$ / \mathrm{kW}\end{array}$ & $\$ / \mathrm{kWh}$ \\
\hline 22,400 & 0 & 0 & 35 \\
\hline 25,040 & 2,420 & $\underline{0}$ & 35 \\
\hline 47,440 & 2,420 & 0 & 70 \\
\hline 7,120 & 360 & $\underline{0}$ & 11 \\
\hline 54,560 & 2,780 & 0 & 81 \\
\hline 10,910 & 560 & $\underline{0}$ & 16 \\
\hline 65,470 & 3,340 & 0 & 97 \\
\hline
\end{tabular}

Application: Multiple Residence

\begin{tabular}{|c|c|c|c|}
\hline \multicolumn{4}{|c|}{ 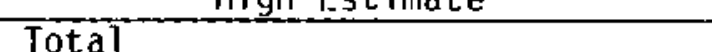 } \\
\hline $\begin{array}{c}\operatorname{Cos} t \\
\$\end{array}$ & $\begin{array}{l}\text { Cost } \\
\$\end{array}$ & $\frac{\text { Distribut }}{\$ / \mathrm{kW}}$ & ion \\
\hline 34,560 & 0 & 0 & 54 \\
\hline 50,090 & 4,850 & $\underline{0}$ & 71 \\
\hline 84,650 & 4,850 & 0 & 125 \\
\hline 12,700 & 730 & $\underline{0}$ & 19 \\
\hline 97,350 & 5,580 & 0 & 144 \\
\hline 19,470 & 1,120 & $\underline{0}$ & 29 \\
\hline 116,820 & 6,700 & 0 & 173 \\
\hline
\end{tabular}

Notes: (a) From Table A.9.

(b) From Table A.10. High $=1.2 \times$ Field Cost; Low $=0.6 \times$ Field Cost.

PNL Note: Installed System Costs of $\$ 97-173 / \mathrm{kWh}(1980 \$)$ were inflated to $\$ 121-216 / \mathrm{kWh}(1984 \$)$. 
TABLE A.12. Bechtel (1982) Frequent Maintenance for the Exxon Zinc-Bromine Battery in the Multiple Residence

$\begin{array}{ccc}\text { Labor, } & \text { Material } & \text { Annual Cost } \\ \text { Manhours } & \$ & \text { Low High }\end{array}$

\begin{tabular}{|c|c|c|c|c|c|}
\hline Activity & Frequency & Per Event & Per Event & $\$$ & $\$$ \\
\hline $\begin{array}{l}\text { Battery } \\
\text { Maintenance }\end{array}$ & $\begin{array}{l}\text { Semi - } \\
\text { Annual }\end{array}$ & 4 & $=$ & 256 & 358 \\
\hline $\begin{array}{l}\text { Cooling } \\
\text { System } \\
\text { Maintenance }\end{array}$ & Annua 1 & 1 & -- & 32 & 45 \\
\hline
\end{tabular}


TABLE A.13. Bechtel (1982) Low Life-Cycle Cost Estimate

Life-Cycle Cost Analysis (1980\$)

Battery Type: Zinc-Bromine (Exxon)

Application Type: Multiple Residence

Low Estimate Input Parameters

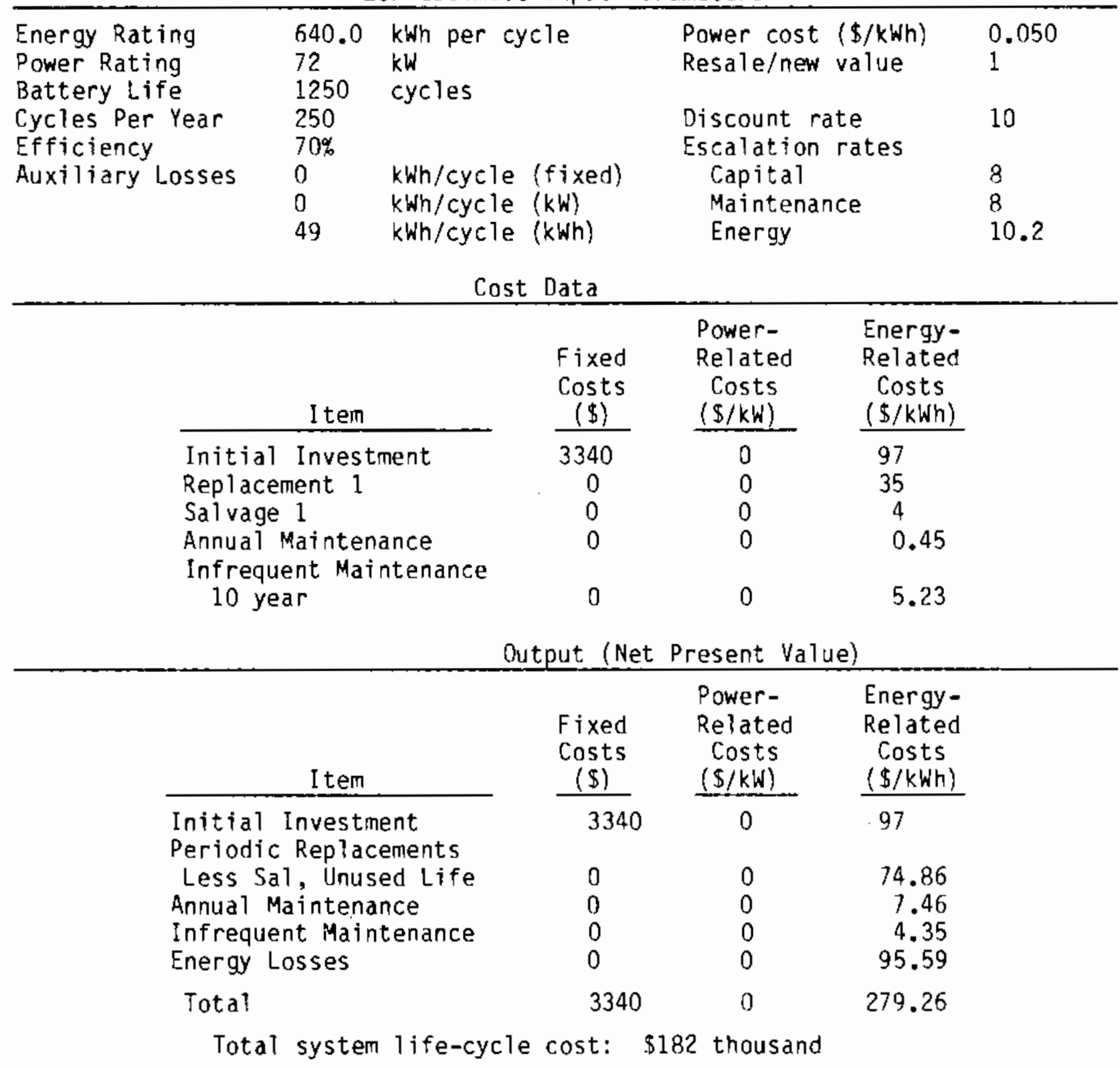

PNL Note: Life-cycle cost of $\$ 279.26 / \mathrm{kWh}(1980 \$$ ) was inflated to $\$ 348 / \mathrm{kWh}$ (1984 \$). 
TABLE A.14. Bechtel (1982) High Life-Cycle Cost Estimate

Life-Cycle Cost Analysis (1980 \$)

Battery Type: Zinc-Bromine (Exxon)

Application Type: Multiple Residence

High Estimate Input Parameters

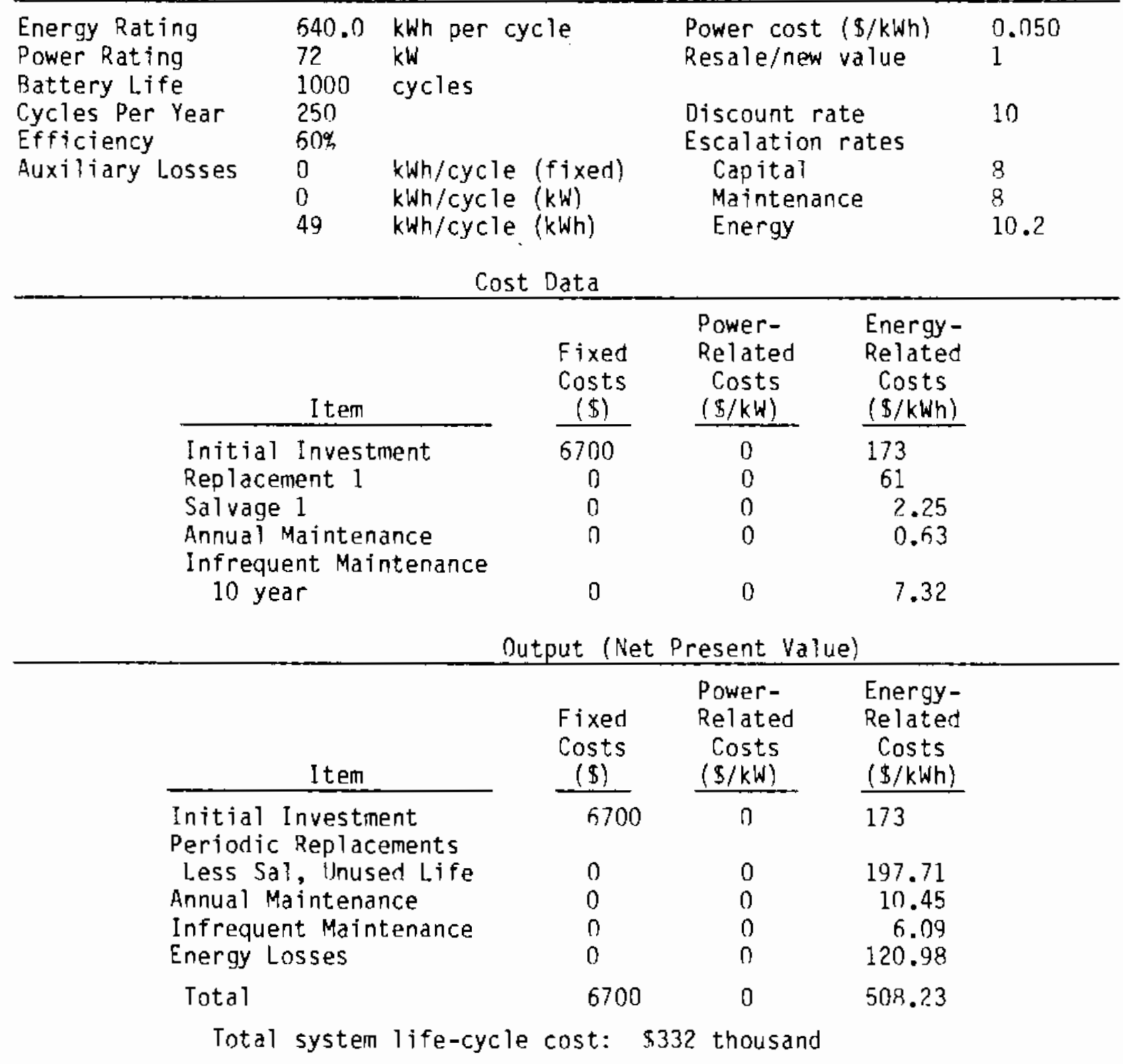

PNL Note: Life-cycle cost of $\$ 508.23 / \mathrm{kWh}(1980 \$)$ was inflated to $\$ 634 / \mathrm{kWh}$ (1984 \$). 


\section{TABLE A.15. Ramsay (1982) Manufacturing Cost Estimate}

Zinc-Bromine: Capital Cost and Salvage Value

Initial Capital Cost of Battery

$\$ / \mathrm{kWh}$

a) Labor (excluding overhead)

68.73

180 people

b) Purchased Components and Materials

Electrodes

Polybromide

$\$ 10.75$

Electrolyte

7.80

A11 else

3.60

25.85

c) Rent

$150,000 \mathrm{ft}^{2}$

0.30

d) Installed Equipment Costs $\$ 10.8$ Million

e) Marketing, Warranty, and Miscellaneous

Salvage Value

Electrolyte

( $90 \%$ of Material) $(60 \% \operatorname{Cos} t / 1 b)$

$\$ 1.95$

Electrodes

(100\% of Material) ( $80 \% \operatorname{Cos} t / 1 b)$

8.60

All else

( $50 \%$ of Material) (40\% Cost/1b)

5.20

PNL. Note: Battery cost of $\$ 68.73 / \mathrm{kWh}(1980 \$)$ was inflated to $\$ 86 / \mathrm{kWh}$ (1984 \$). 
TABLE A.16. Ramsay (1982) Balance of System Cost Estimate Zinc-Bromine: Other Costs of Utility System

Utility System (100 Mwh and 20Mw)

$\$ / \mathrm{kWh}$

- Ancillary Equipment

- Reservoir cooling equipment

- Racks

1.50

- Controls and sensors

5.00

- Prefabricated enclosure

3.00

- Electrolyte spill containment

- Electrical connections and protectors

- Operation and Maintenance Scenario

- Replacement of pumps during years 7 and 14; pump cost: $\$ 150$ per module, labor:

1 man-hour per module

- Replacement of one cell per module during years $3,6,10,13$, and 16 ; cell cost:

$\$ 650$ per cell, labor: 4 man-hours per cell

- Scheduled maintenance: 16 man-days/month

- Unscheduled maintenance: 24 man-days/year

Present worth of ORM over system lifetime

$6 \%$ discount rate: $\$ 1,383,000$

$8 \%$ discount rate: $\$ 1,185,000$

PNL Note: Balance of system cost of $\$ 25 / \mathrm{kWh}(1980 \$)$ was inflated to $\$ 31 / \mathrm{kWh}(1984 \$)$ and added to the battery cost of $\$ 86 / \mathrm{kWh}(1984 \$)$ to yield an installed system cost estimate of $\$ 117 / \mathrm{kWh}$ $(1984 \$)$. 


\section{TABLE A.17. Ramsay (1982) Life-Cycle Cost Estimates}

Zinc-Bromine: Utility System Summary Costs

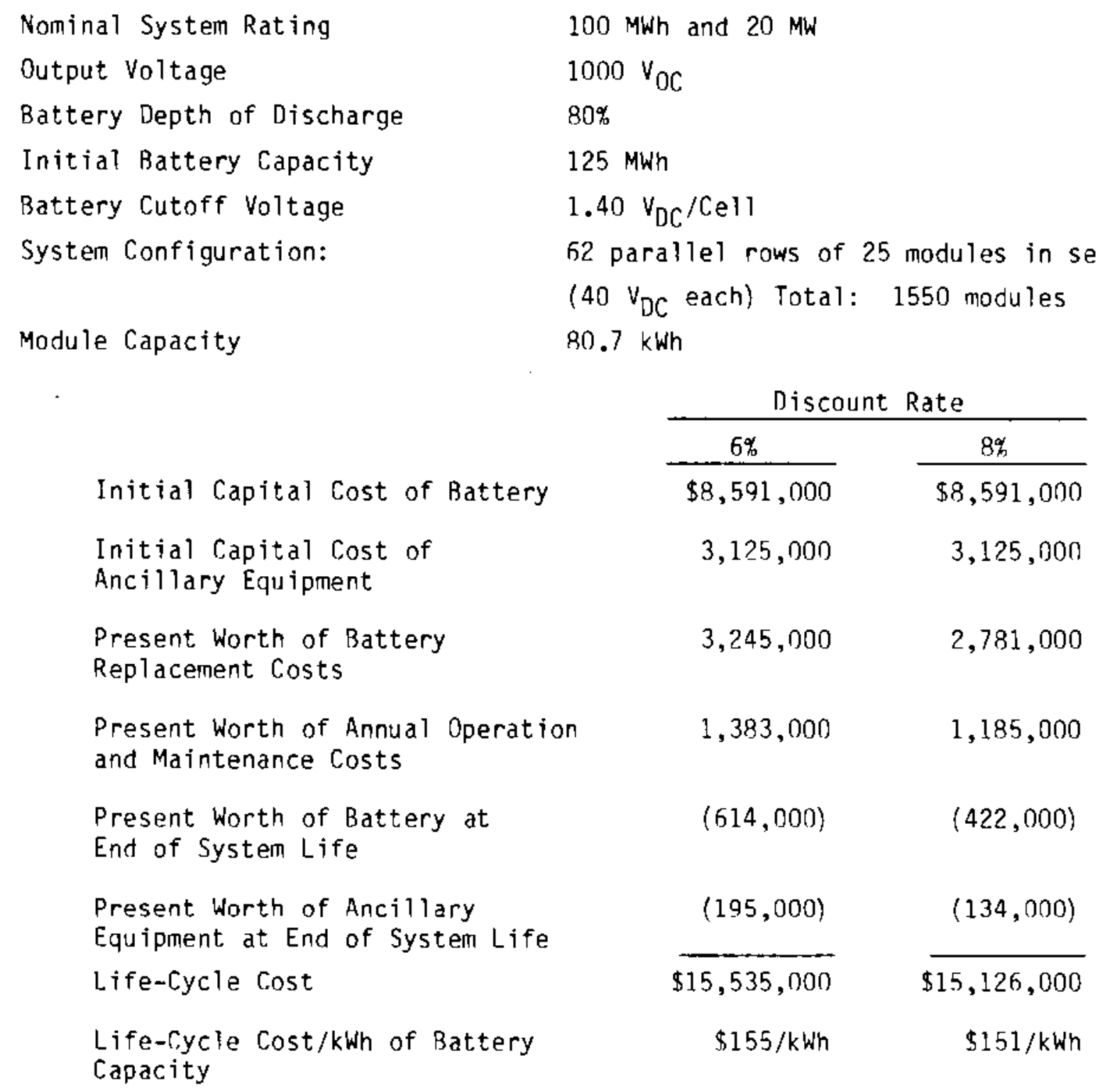

PNL Note: Life-cycle costs of $\$ 151-155 / \mathrm{kWh}(1980 \$)$ were inflated to $\$ 188-193 / \mathrm{kWh}$ (1984\$). 


\section{TABLE A.18. Monn (1983) Manufacturing Cost Estimate}

Total Cost Estimate for Production of Submodules for $50 \mathrm{kWh}$ System

One $500 \mathrm{kWh}$ Module

Production Leve1: \$/kWh \$/Submodule \$/Module

Materials

Labor at $10 \$ / \mathrm{hr}$

0verhead, G\&A, and Profit

Total Cost 154
300

4,980

13

219 149,400

2,581

7,780

467
100 Modules/Year $\$ / \mathrm{kWh}$ \$/Submodule \$/Module 40 664 19,920
6,573

77,427

233,400
4

57

66

960

101

1,690 1,992

28,788

PNL Note: Manufactured cost of $\$ 101 / \mathrm{kWh}(1983 \$)$ was inflated to $\$ 106 / \mathrm{kWh}$ (1984\$). 
TABLE A.19. Monn (1983) 8attery Material Costs

Component Cost Breakdown for $16.6 \mathrm{kWh}$ Submodules

\begin{tabular}{l} 
Component \\
\hline Frames \\
Electrodes \\
$\begin{array}{l}\text { Separator- }-2.1 \mathrm{ft}^{2} \text { gasket type(a) } \\
\text { DARAMIC }\end{array}$
\end{tabular}

$\frac{\text { One } 500 \mathrm{kWh} \text { Init Produced }}{\frac{\text { Unit Cost }}{3.15 \text { ea }}} \frac{\begin{array}{c}\text { Cost } / \\ \mathrm{kWh}\end{array}}{9.86} \frac{\frac{500 \mathrm{kWh}}{\text { Cost/ }}}{4,930}$

$\frac{100 \text { Units/Year Produced }}{\text { Cost/ Cost } T}$

$\begin{array}{llll}4,930 & 0.80 \text { ea } & 2.50 & 1,250\end{array}$

7.15 ea $\quad 22.38 \quad 11,190$

1.52 ea $\quad 4.76 \quad 2,380$

DARAMIC,

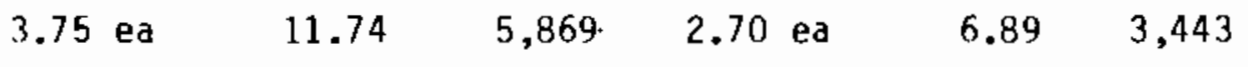

Separator--1 $\mathrm{ft}^{\text {? }}$ sealed ${ }^{(b)}$ DARAMIC

$\begin{array}{lllllr}1.30 \mathrm{ea} & 4.07 & 2,035 & 0.65 \mathrm{ea} & 2.03 & 1,017 \\ 2.40 / \mathrm{ft}^{2} & 7.50 & 3,756 & 1.25 / \mathrm{ft}^{2} & 3.91 & 1,956 \\ 1.50 \mathrm{ea} & 4.70 & 2,348 & 0.35 \mathrm{ea} & 1.10 & 547\end{array}$

Anode Grid

1.50

$24.00 \quad 12,048$

0.35 ea

1.10

547

Fnd Electrode

End Plate--thick(a)

Strongback Assembly(a)

$200 \mathrm{ea}$

$42.17 \quad 21,084$

150 ea

$18.07 \quad 9,036$

350 ea

100 ea

$12.05 \quad 6,024$

Thin End Plate ${ }^{(b)}$

3000 submod

$180.7290,361$

1000/submod

$60.2430,120$

300 ea

$36.14 \quad 18,072$

50 ea

$6.02 \quad 3,012$

(a) Used in calculation of compressed stack construction cost.

(b) Used in calculation of heat-sealed stack construction cost. 
TARLE A.20. Monn (1983) Battery Labor Costs

Time and Labor Requirements for Production of Submodules for $500 \mathrm{kWh}$ System

\begin{tabular}{|c|c|c|c|c|c|c|c|}
\hline No. & Operation & Rate & $\begin{array}{l}\text { Total } \\
\text { Man Hour }\end{array}$ & No. Men & $\begin{array}{l}\text { Time } \\
\mathrm{Hr} \\
\end{array}$ & $\begin{array}{l}\text { Calendar } \\
\text { Time, Hr }\end{array}$ & $\begin{array}{c}\text { Crltical } \\
\text { Path } \\
\end{array}$ \\
\hline 1 & Acquire Purchased Parts and Raw Materials & 6 waeks & -- & -- & -- & 1000 & 1000 \\
\hline 2 & Compresstion Mold Blpolar Plate(a) & $\begin{array}{l}2 \text { plates } / \mathrm{hr}+1 \mathrm{hr} \text { setup; } \\
14 \text { plates/day }\end{array}$ & 890 & 1 & 890 & 1250 & 1250 \\
\hline 3 & Cut Felt to Size(a) & $200+e 1+s / d a y$ & 60 & 1 & 60 & 84 & \\
\hline 4 & Cut Separator to $S 1 z e^{(a)}$ & $200 \mathrm{sep} / \mathrm{day}$ & 60 & 1 & 60 & 84 & \\
\hline 5 & Fabrlcate End Electrode ${ }^{(a)}$ & $6 \mathrm{hr} / \theta$ lectrode & 300 & 1 & 300. & 420 & \\
\hline 6 & Fabrlcate End Plate(a) & $5 \mathrm{hr} / \mathrm{olate}$ & 300 & 1 & 300 & 420 & \\
\hline 7 & Fabricate and Coat Strongback Assembly ${ }^{(a)}$ & $2 \mathrm{hr} / \mathrm{assembly}$ & 60 & 1 & 60 & 84 & \\
\hline B & Band Electrode to Frame & $10 \mathrm{sets} / \mathrm{hr}$ & 160 & 1 & 160 & 224 & 224 \\
\hline 9 & Bond Spacer to Frame & $10 \mathrm{sets} / \mathrm{hr}$ & 160 & 1 & 160 & 224 & 224 \\
\hline 10 & Coat Separator ${ }^{(a)}$ & $10 \mathrm{pieces} / \mathrm{hr}$ & 160 & 1 & 160 & 224 & \\
\hline 11 & Bond Felt to Elactrode & $10 \mathrm{sets} / \mathrm{hr}$ & 160 & 1 & 160 & 224 & 224 \\
\hline 12 & Assemble Submodule & $2 \mathrm{hr} /$ submodule & 60 & 2 & 30 & 42 & 42 \\
\hline 13 & Qualificatlon Testling & $4 \mathrm{hr} /$ submodule & 120 & 2 & 60 & 84 & 84 \\
\hline & Total Man-Hour Requirement & & 2490 & & & & $\begin{array}{r}3050 \\
\text { months }\end{array}$ \\
\hline
\end{tabular}

(a) Man-hour requirement included in component cost estimate: 1830. Man-hour requirement not included In component cost estimate: $660=1.32$ man-hours/kwh. 
TABLE A.21. Monn (1983) Cost Comparison of Heat Sealing and Compression Sealing

Materials and Components Cost Estimate

\begin{tabular}{|c|c|c|c|c|c|}
\hline \multirow{2}{*}{\multicolumn{2}{|c|}{ Stack Construction }} & \multicolumn{2}{|c|}{$\begin{array}{l}\text { One } 500 \mathrm{kwh} \\
\text { Unit Produced }\end{array}$} & \multicolumn{2}{|c|}{$\begin{array}{c}100 \text { Units/Year } \\
\text { Produced }\end{array}$} \\
\hline & & $\begin{array}{l}\text { Cost } \\
\$ / k W h \\
\end{array}$ & $\begin{array}{c}\text { Cost } \\
\$ / 500 \mathrm{kWh}\end{array}$ & $\begin{array}{l}\text { Cost } \\
\$ / \mathrm{kWh} \\
\end{array}$ & $\begin{array}{c}\text { Cost } \\
\$ / 500 \mathrm{kWh}\end{array}$ \\
\hline mpressed & DARAMIC & 303.07 & 151,535 & 109.52 & 54,760 \\
\hline Heat Sealed (a) & DARAMIC & 108.65 & 54,325 & 38.39 & 19,195 \\
\hline
\end{tabular}

(a) Does not include tooling cost for heat sealing equipment.

Heat Sealed Tooling Cost-- $\$ 100,000$ Installed

Amortized over 1 system $\$ 200 / \mathrm{kWh}$

Amortized over 100 systems $\$ 2.00 / \mathrm{kWh}$

Amortized over 10 years $\$ 0.20 / \mathrm{kWh}$ 
TABLE A.22. Monn (1983) Installed Systen Cost Estimate

Capital Cost Estimate $100 \mathrm{~kW}-500 \mathrm{kWh}$ Zinc Bromine Battery Based on Order of 100 Units (January 1983 \$)

$\begin{array}{lr}\text { Structural Steel } & \$ 28,400 \\ \text { Battery Submodules } & 50,700 \\ \text { Equipment } & 22,100 \\ \text { Piping } & 49,900 \\ \text { Electrical } & 21,400 \\ \text { Instruments } & 34,400 \\ \text { Painting and Scaffolding } & 1,000 \\ \quad \text { Subtotal--Fabrication Costs } & \$ 207,900 \\ \text { Office Costs } & 10,000 \\ \text { Subtotal--Fabrication and 0ffice Costs } & 217,900 \\ \text { Contingency (15\%) } & 32,700 \\ \text { Total Project Cost } & 250,600 \text { or } \$ 501.20 / \mathrm{kWh}\end{array}$

Notes: 1. F0B East Coast shop.

2. Power conditioning equipment and certain other auxiliaries not included.

PNL Note: The installed system cost of $\$ 501.20 / \mathrm{kWh}(1983 \$)$ was inflated to $\$ 524 / \mathrm{k}$ wh $(1984 \$)$. 
TABLE A.23. Bellows (1983a) Manufacturing Cost Estimate

Total Factory Cost--20 kwh Zinc-Bromine Battery

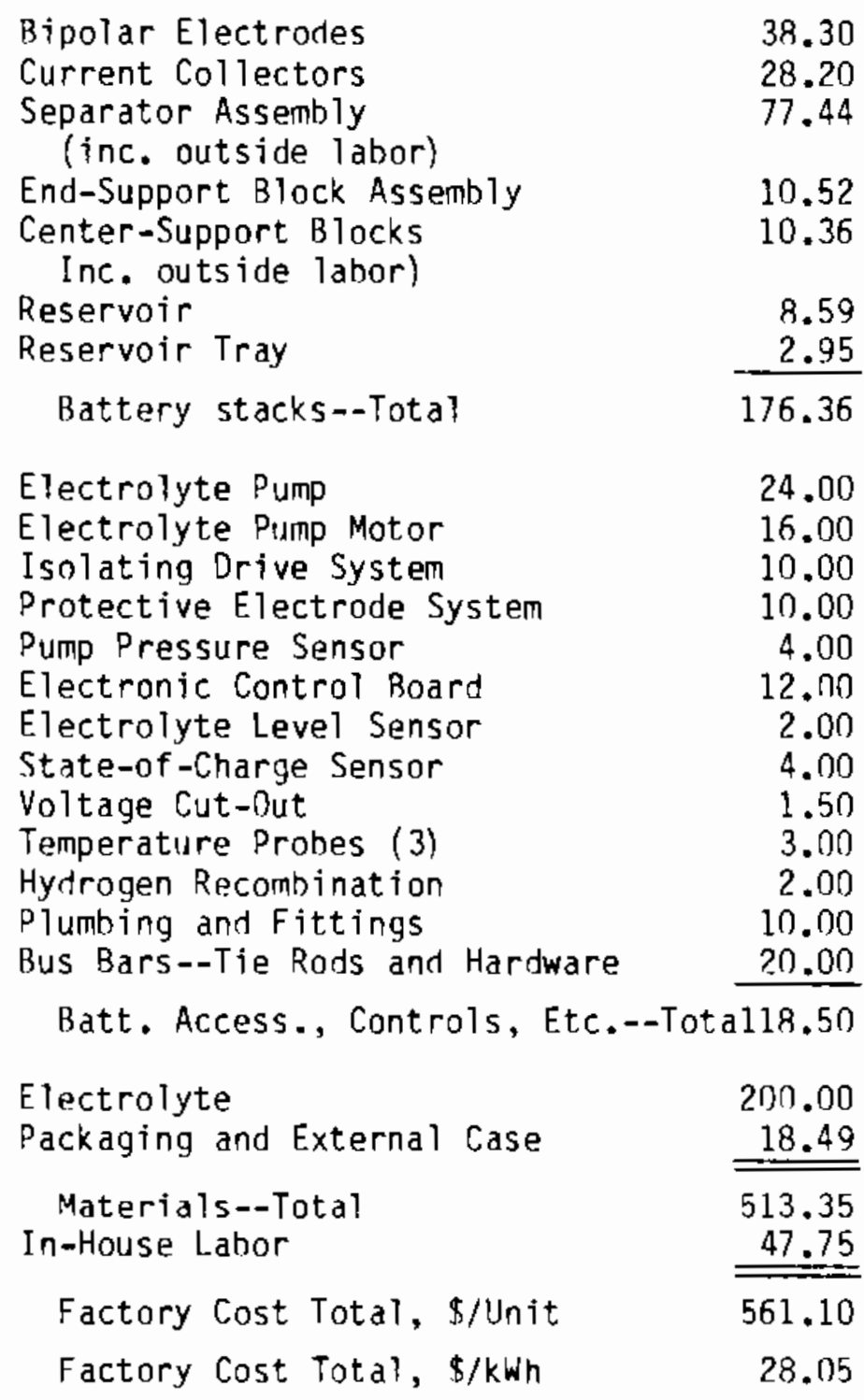

PNL Note: The factory cost of $\$ 28.05 / \mathrm{kWh}(1980 \$)$ was inflated to $\$ 35 / \mathrm{kWh}(1985 \$)$. 
TABLE A.24. Bellows (1983b) Manufacturing Cost Estimate Total Factory and Capital Costs

Material (Includes electrolyte at $\$ 220 /$ Module) $\$ 321.36$

Purchased Components (Includes outside molding costs and accessories) 211.71 In-House Labor Costs 68.74

Total Material, Components and Labor Cost/20 kWh Module 601.81

Total Material, Components and Labor Cost/kWh 30.09

1. At 2500 WWh Material, Components and Labor Cost Per Year $\$ 75,225,000.00$

2. Marked-up Equipment Costs (10\% of estimated $\$ 12,500,000)$ $1,250,000.00$

3. Rent $\left(100,000 \mathrm{sq} \mathrm{ft}\right.$ plant at $\left.5.00 / \mathrm{ft}^{2}\right)$

4. Total Factor Costs (Lines $1+2+3$ ) $500,000.00$

5. Working Capital Requirement (30\% line 4) $76,975,000.00$

6. Total Investment $(\$ 12,500,000+1$ ine 5) $23,092,500.00$

7. Return on Investment and Taxes (30\% 1ine 6) $35,592,500.00$

8. Additional at $\$ 5.00 / \mathrm{kWh}$ $10,677,750.00$

9. Total Capital Cost Lines 4, 7 and 8) $12,500,000.00$ Capital Cost per $20 \mathrm{kWh}$ Module $100,152,750.00$ Capital Cost per kwh 801.22 40.06

PNL Note: Manufactured cost of $\$ 40.06 / \mathrm{kWh}(1980 \$)$ was inflated to $\$ 50 / \mathrm{kWh}$ (1984 \$). 
TABLE A.25. Bellows (1983b) Salvage Value and Net Costs

Electrolyte Salvage Value $225 \mathrm{lb} \mathrm{Zn} / \mathrm{Br}_{2}$ at $0.30 / 1 \mathrm{~b}$ $\$ 67.50$

50 1b Quaternary Ammonium Bromide at $0.70 / 1 \mathrm{~b}$ 35.00

$\$ 16.31$ Silver at 50\% Recovery Value (Includes disassembly costs) 8.15

Copper--Est. $\$ 9.00$ at $50 \%$ Value

Total per $20 \mathrm{kWh}$

Salvage $\mathrm{Value} / \mathrm{kWh}$

115.15

5.76

From Table A.24

Capital Cost per kWh

40.06

- Salvage Value

Net Capital Cost/kWh

Notes: Additional salvage possible but minimal (motors, controls, etc.).

- Indicated costs are based on $80 \%$ coulombic efficiency and $10 \%$ auxiliary power (present battery design and parameters). Further cost reductions are possible in future batteries. Larger battery modules consisting of 8 to 12 battery stacks with single pumps and reservoirs serving all stacks in comparison to only two stacks in this analysis would obviously reduce cost appreciably. 
TABLE A.26. Bellows (1983b) Purchased Materials and Components and Fabrication Labor

\begin{tabular}{|c|c|c|c|c|}
\hline finit & $\begin{array}{l}\text { Matertal } \\
\text { Cost }\end{array}$ & $\begin{array}{l}\text { Factory } \\
\text { In-Hoyse } \\
\text { Labor(b) }\end{array}$ & $\begin{array}{l}\text { Purchased } \\
\text { Components }(c)\end{array}$ & $\begin{array}{l}\text { Total } \\
\text { Cost Per } \\
\text { Hodule }\end{array}$ \\
\hline Ripolar Electrode & $\begin{array}{l}0.196 / \text { ed } \\
30.55 / \text { Hodule } \\
(154 \text { pCs) }\end{array}$ & -- & $\begin{array}{l}0.0695 \text { ea } \\
10.70 \text { Hodule } \\
(254 \text { pCs })\end{array}$ & 40.85 \\
\hline
\end{tabular}

Current collector.

Consisting of:

Silver at $\$ 12,00 /$ troy az 3.597 ea

l.ead Foil

Fxpanding Foil

Silver plating

Plastic Backing

Laminating

0.165 ea

$\overrightarrow{0.165}$ es

0.088 ea

a.150 ea

-. 0.83 ea

16.31 Module $3.33 /$ Madule 0.35

(4 units) (4 pCs)

Separator Assembly,

Consisting of:

Separator

injection molded frame

\subsection{6 ea}

0.179 ea

0.711 ea

60.84

$$
19.66 \text { pes) }
$$

(156 pCs)

End Support Block

$\begin{array}{lll}4.114 \text { ea } & 0.833 \text { ea } & 0.847 \text { ea } \\ 8.2 & 2.67 & 1.69 \\ (2 \text { pcs }) & (2 \text { pcs }) & (2 \text { pcs })\end{array}$

80.50

Consists of an injection molded frame around a sepurator sheet. Frame contains manifold holes and electrolyte flow channeis. Separator is extruded, cleanes, pierced and blanked continuousiy. moiding cycle 60 5. Two per mold yields $120 \mathrm{pcs} / \mathrm{h}$

Injection-molded, glass-filled polypropylene. In-house secondary operations--tapping and deflashing

End Support Block

Assembly

Assembly Blocks

Electrodes (4 pes)

Seals (4 ges)

plugs (4 pcs)

Contacts (4 pcs)

renter Support.

Block Assembly

Center Block

Electrodes (8)

Seals (8)

plugs (B)

Contacts (B)

$--$

$\ddot{0.18}$

11.59

electrode, silver-plated expanded

lead-foil and plastic backing.

Cycle time-in house tabor dt

$30 \mathrm{pcs} / \mathrm{h}$

19.99

In-House Assembty of Components

30 pesihr

Total $\quad 0.18$

$0.83 \quad 0.18$

1.47

$-$

8.54

$1.69 *$

n. 35

0.18

Total

0.18

$1 . n 8 \quad 0.18$

- $\quad$ Injection Molding Costs

(outsfde)

In-House Tapping $30 \mathrm{pcs} / \mathrm{h}$

peservotr

6.81

$--$

$2.28^{*}$

13.47

In-House Assembly $20 \mathrm{ocs} / \mathrm{h}$

Reservoir Tray

$\underline{1.56}$

$\underline{1.62 *}$

9.09

-Injection Molded 4 min cycle

(outside vendor)

Totals

91.36

7.91

60.86

3.17

*Injection molded 3 min cycle (outside vendor)

(a) Base material cost at $95 \%$ yteld plus 105 overhead.

(b) Based at $\$ 10.00 / \mathrm{h}+150 \mathrm{t}$ overhead.

(c) Rase cost at $95 \%$ yfeld plus $10 x$ overhead-oincludes outside macinine time and labor. Factory cost (1980 s). 
TABLE A.27. Bellows (1983b) Purchased Component cost

\begin{tabular}{|c|c|}
\hline Accessories & $\begin{array}{c}\text { Purchased } \\
\text { Component Cost (a) }\end{array}$ \\
\hline Electrolyte Pump & $\$ 26.40$ \\
\hline Electrolyte Pump Motor & 17.60 \\
\hline Drive System & 11.00 \\
\hline Bromine Pump Head & 4.40 \\
\hline Bromine Pump Motor & 6.60 \\
\hline Pump Pressure Sensor & 4.40 \\
\hline Electrolyte Level Sensor & 2.20 \\
\hline State-of-Charge Sensor & 4.40 \\
\hline Voltage Cutout & 1.65 \\
\hline Temperature Probes (3) & 3.30 \\
\hline Electronic Control Board & 13.70 \\
\hline Hydrogen Recombination & 2.20 \\
\hline Plumbing Fittings & 11.00 \\
\hline Bus Bars--Tie Rods and Miscellaneous Hardware & 22.00 \\
\hline Total (Accessories) & $\$ 130.85$ \\
\hline Electrolyte & $\$ 220.00$ \\
\hline
\end{tabular}

(a) Base cost at $95 \%$ yield plus $10 \%$ overhead includes outside machine time and labor. 
TABLE A.28. Bellows (1983b) Assembly Costs

Operation

Cost Per Module $(a)$

Stack Assembly--End Blocks, 77 Electrodes

ATternating with Separators--Collectors

Center Block Assembly--77 Electrodes

Alternating with Separators

Collector End Block--Estimated at $6 \mathrm{~s}$ per part

(Inctudes handling and visual inspection)

Assemble 4 Tie Rods, etc. 4 min

Heat Seal and Inspect 4 min

Total time 38 min

$\$ 15.83$

Final Assembly

Assemble Stack Assembly to Tray and Tray

to Reservoir--Assembly Pumps--Controls

Bus Bars, Hardware Probes--Gaskets

Inspect

$$
\text { Total time } 38 \text { min }
$$

Final Test and Inspection

Inspect and Test--A percentage of

Batteries to Undergo Complete Test

Including Several cycles

$$
\text { Average time } 60 \text { min }
$$

25.00

Packaging-Shipping--10 min

Total Labor (In-House)

$\$ 4.17$

Packing Materials Est.

$\$ 60.83$

$\$ 10.00$

(a) Based at $\$ 10.00 / h+150 \%$ overhead. 
-

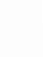

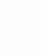


APPENDIX B

SODIUM SILFUR COST DETAILS 


\section{APPENDIX B}

\section{SODIUM SULFUR COST DETAILS}

The following pages present cost estimating details extracted from the sources reviewed for this study. The tables have been reproduced to match the figures and notes presented in the original sources except for some minor modification to the format or style. Additional clarifying comments, if any, are designated as PNL Notes.

The data provide an indication of the completeness and level of detail found among the various estimates and also serve as a rudimentary data base of battery cost information. The supporting details presented in this appendix correspond to the cost estimates referenced in Table 4.2 and Sections 4.2 .4 and 4.2 .5 . 
TABLE B.1. Ford (1980) Manufacturing Cost Estimates

Factory Cost and Selling Price of Sodium-Sulfur Cells (1980 \$)

\begin{tabular}{|c|c|c|c|}
\hline Cell Size, wh & 62 at $\mathrm{C} / 3$ & 211 at $C / 5$ & 402 at $c / 5$ \\
\hline Production Rate, Units/Year & & & \\
\hline Electrolyte Subassembiy & $52,632,000$ & $14,000,000$ & $7,474,000$ \\
\hline Cell Assembly & $50,000,000$ & $13,300,000$ & $7,100,000$ \\
\hline
\end{tabular}

Electrolyte Subassembly

$\begin{array}{llll}\text { Factory Cost, \$ } & 1.32 & 2.57 & 3.41 \\ \text { Selling Price, } \$ & 1.79 & 3.67 & 4.97\end{array}$

Cell Assembly

Factory Cost, 8

$\begin{array}{lll}5.63 & 10.55 & 14.78\end{array}$

Selling Price, \$

$\begin{array}{lll}7.03 & 13.20 & 18.53\end{array}$

Sodium-Sulfur SES Rattery Selling Price

\begin{tabular}{|c|c|c|c|}
\hline \multirow[b]{2}{*}{ Cell Size, wh } & \multicolumn{2}{|c|}{ Per Detailed Cost Study } & \multirow{2}{*}{$\frac{\text { Projected }}{500}$} \\
\hline & 2.11 & 402 & \\
\hline $\begin{array}{l}\text { Selling Price } \\
(1980 \$)\end{array}$ & $10,612,600$ & $8,816,800$ & $8,400,000$ \\
\hline \multicolumn{4}{|l|}{ Normalized Selling Price } \\
\hline$\$ / \mathrm{kWh}$ & 106.1 & 88.2 & 84 \\
\hline$\$ / k w^{\prime}$ & 530.6 & 440.8 & 420 \\
\hline
\end{tabular}

PNL Note: The projected battery selling price of $\$ 84 / k W h$ (1980 \$) was inflated to $\$ 105 / \mathrm{kWh}(1984 \$)$. 
TABLE B.2. Ford (1980) Sodium-Sulfur Cell Materials, Labor and Energy Costs (1980 \$)

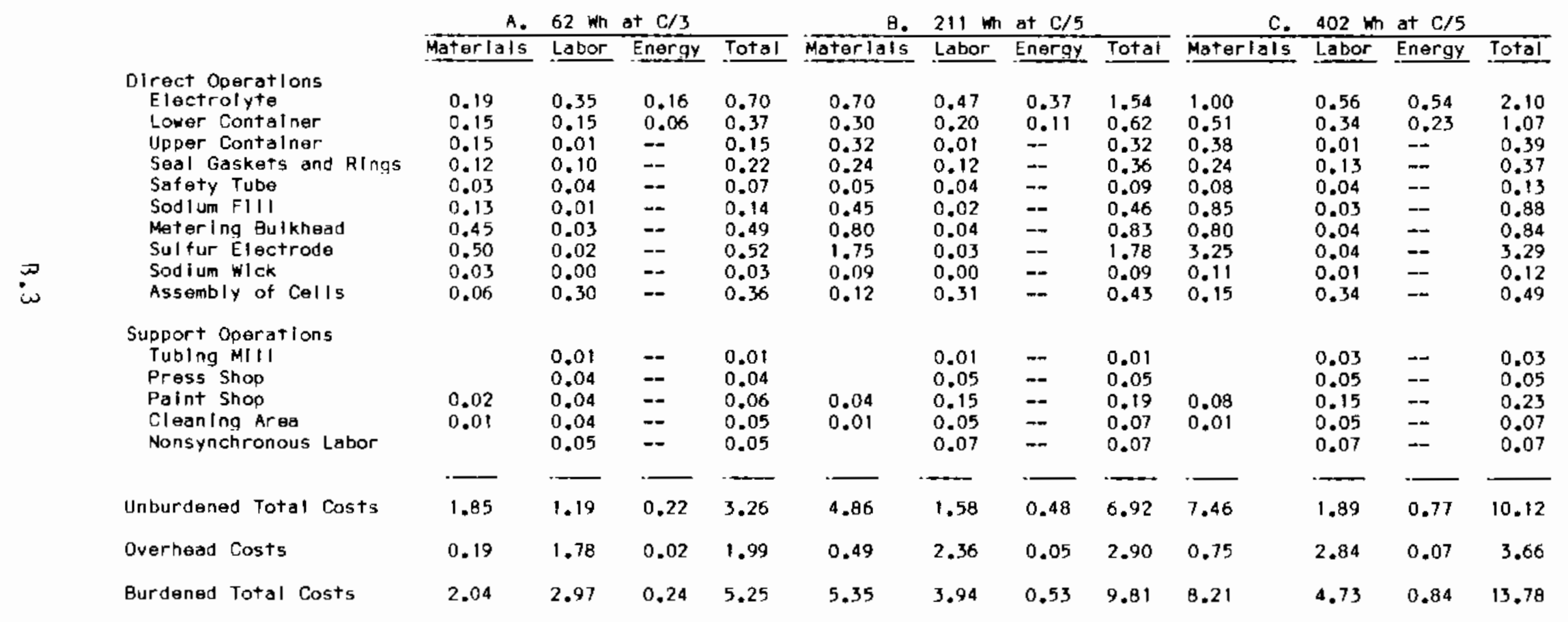


TABLE B.3. Ford (1980) Sodium-Sulfur Cell Electrolyte Materials, Labor and Energy Costs (1980\$)

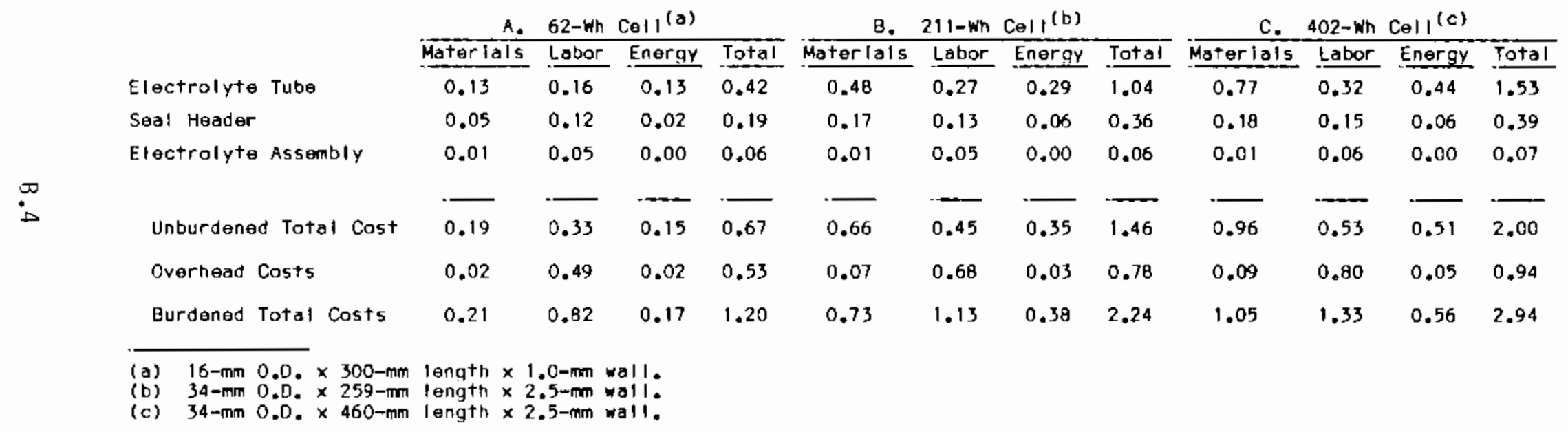


TABLE B.4. Ford (1980) Sodium-Sulfur Cell Manufacturing Plant Equipment Cost

Cell Size, wh

Production Rate, Units/Year

Direct Operations

Electrolyte

Lower Container

Upper Container

Seal Gaskets and Rings

Safety Tube

Sodium Fill

Metering Bulkhead

Sulfur Electrode

Sodiun wick

Assembly of Cells

Supporting Operations

Tubing Mill

Press Shop

Paint Shop

Cleaning Area

Other

Total Cost

Installed Equipment Cost (\$ miliions).

62 at $C / 3 \quad 211$ at $C / 5 \quad 402$ at $C / 5$

$50,000,000 \quad 13,300,000 \quad 7,100,000$

58.4

39.0

29.1

22.9

14.7

13.1

4.9

2.6

4.2

3.1

0.3

3.4

7.4

7.3

4.7

3.1

4.7

2.5

1.8

1.5

1.8

1.4

1.6

1.3

1.5

1.3

0.2

0.1

1.1

0.6

5.3

3.?

3.2

5.6

1.9

$1 . ?$

1.1

0.6

0.3

1.5

0.6

0.3

$\frac{8.0}{149.1}$

$\frac{5.1}{75.2}$

$\frac{4.0}{57.2}$ 
TABLE B.5. Ford (1980) Sodium-Sillfur Cell Manufacturing Plant Size (1000 $\mathrm{ft}^{2}$ )

Cell Size, wh

62 at $C / 3 \quad 211$ at $C / 5 \quad 402$ at $C / 5$

Production Plant

Cell Assembly

Electrolyte

Total

Manufacturing Support

$$
\begin{aligned}
& \text { Cell Assembly } \\
& \text { Electrolyte } \\
& \text { Total }
\end{aligned}
$$

Administration

$$
\begin{aligned}
& \text { Cell Assembly } \\
& \text { Electrolyte } \\
& \text { Tota? }
\end{aligned}
$$

Total Plant Size

Cell Assembly

Electrolyte

Total

Production Rate, Cells/Year

$\begin{array}{llr}643 & 257 & 139 \\ \frac{177}{870} & \frac{122}{379} & \frac{97}{236}\end{array}$

69

28

15

$\begin{array}{lll}-\frac{37}{106} & \frac{27}{55} & \frac{21}{36}\end{array}$

46

18

10

$\frac{6}{52}$

$\frac{6}{24}$

$\frac{6}{16}$

758

303

164

$\underline{220}$

978

$\underline{155}$

458

124

288

$50,000,000 \quad 13,000,000 \quad 7,100,000$

TABLE B.6. Ford (1980) Sodium-Sulfur Cell Manufacturing Plant Direct Labor Force (persons)

\begin{tabular}{lrrr} 
& \multicolumn{3}{c}{ Cell Size, Wh } \\
\cline { 2 - 4 } $\begin{array}{l}\text { Cell Assembly } \\
\text { Electrolyte } \\
\text { Total }\end{array}$ & 2,296 & 211 at $\mathrm{C} / 5$ & 402 at $\mathrm{C} / 5$ \\
$\begin{array}{l}\text { Production Rate, } \\
\text { Cells/Year }\end{array}$ & $\frac{868}{3,164}$ & $\frac{315}{1,138}$ & $\frac{199}{678}$ \\
& $50,000,000$ & $13,300,000$ & $7,100,000$
\end{tabular}


TABLE B.7. Ford (1980) Sodium-Sulfur SES Battery Assembly Plant

$\begin{array}{lr}\text { Plant Size, } \text { ft }^{2} & 128,000 \\ \text { Direct Labor Force, Persons } & 340 \\ \text { Equipment Costs, } 1980 \$ & 5,508,000 \\ \text { Welding } & 3,500,000 \\ \text { Overhead Conveyors } & 6,650,000 \\ \text { Parts Handling } & 519,000 \\ \text { Painting } & 331,000 \\ \text { Heat Treating } & 221,000 \\ \text { Tooling } & 1,250,000 \\ \text { Metal Working } & 14,729,000 \\ \text { Other } & \end{array}$


TABLE B.8. Levine (1981) Manufacturing Cost Estimate

\begin{tabular}{|c|c|c|}
\hline & 1981 \$/Year & $1981 \$ / \mathrm{Cel}$ \\
\hline Raw Materials & $20,257,903$ & 15.446 \\
\hline Lahor $(75 \%$ of est.) & $2,816,842$ & 2.141 \\
\hline \multicolumn{3}{|l|}{ Overhead } \\
\hline $150 \%$ of Lahor & $4,225,263$ & 3.211 \\
\hline $10 \%$ of Materials & $2,025,790$ & 1.620 \\
\hline Depreciation (10\% of Capital) & 989,196 & 0.791 \\
\hline Tax (15\% of required Capital) & $2,886,859$ & 2.309 \\
\hline \multirow[t]{3}{*}{ After Tax ROI (15\% of required Capital) } & $2,886,859$ & 2.309 \\
\hline & & $\$ 27.827$ \\
\hline & or $\$ 34.784 / \mathrm{kWh}$ & \\
\hline Marketing Costs & 2.00 & \\
\hline Replacement, returns, service & 2.00 & \\
\hline Miscellaneous & 1.00 & \\
\hline Total & $\$ 39.79 / \mathrm{kWh}$ & \\
\hline
\end{tabular}

PNL Note: Manufactured cell cost of $\$ 39.78 / \mathrm{kWh}$ (1981 $\$$ ) was inflated to $\$ 45 / \mathrm{kWh}(1984 \$)$. 
TABLE B.9. Levine (1981) Raw Material Cost - Stainless Steel Case Cell

\begin{tabular}{|c|c|c|c|}
\hline Material & $\$ /$ Unit & Anount/Cell & $\$ / \mathrm{Cell}$ \\
\hline Sodium, ib & 1.00 & 1.0435 & 1.044 \\
\hline Sulfur, ib & 0.10 & 2.5735 & 0.257 \\
\hline Glass for fibers, $1 \mathrm{~b}$ & 3.30 & 0.1629 & 0.537 \\
\hline A1 lay-down tape, ib & 3.84 & 0.0645 & 0.248 \\
\hline Mo coated foil, ea & 1.494 & 1.05 & 1.567 \\
\hline Al spacer tape, lb & 3.72 & 0.2325 & 0.865 \\
\hline Glass for tube sheet, ib & 3.85 & 0.3944 & 1.519 \\
\hline A1 mandrel, in & 2.50 & 0.0239 & 0.060 \\
\hline A1 anode cup, ea & 0.24 & 1.05 & 0.252 \\
\hline Al anode lead, tb & 2.70 & 0.0198 & 0.053 \\
\hline A1 flow restrictor, ea & 0.33 & 1.05 & 0.347 \\
\hline Stainless steel case, ft & 5.87 & 0.883 & 5.183 \\
\hline Stainless steel case, top, $1 b$ & 1.74 & 0.616 & 1.072 \\
\hline Stainless case, bottom, lb & 1.74 & 0.5527 & 0.962 \\
\hline Al sulfur fill tube, ib & 2.50 & 0.0032 & 0.010 \\
\hline Feed-through, ea & 1.00 & 1.05 & 1.05 \\
\hline Cup dip glass, ib & 3.85 & 0.0573 & 0.221 \\
\hline Cumene, lb & 0.25 & 0.10404 & 0.010 \\
\hline \multirow[t]{2}{*}{ Zn alloy, g } & 0.18 & 1.05 & 0.189 \\
\hline & & & $\$ 15.446$ \\
\hline
\end{tabular}


TABLE B.10. Levine (1981) Labor and Capital Cost Summary Stainless Steel Case Cell

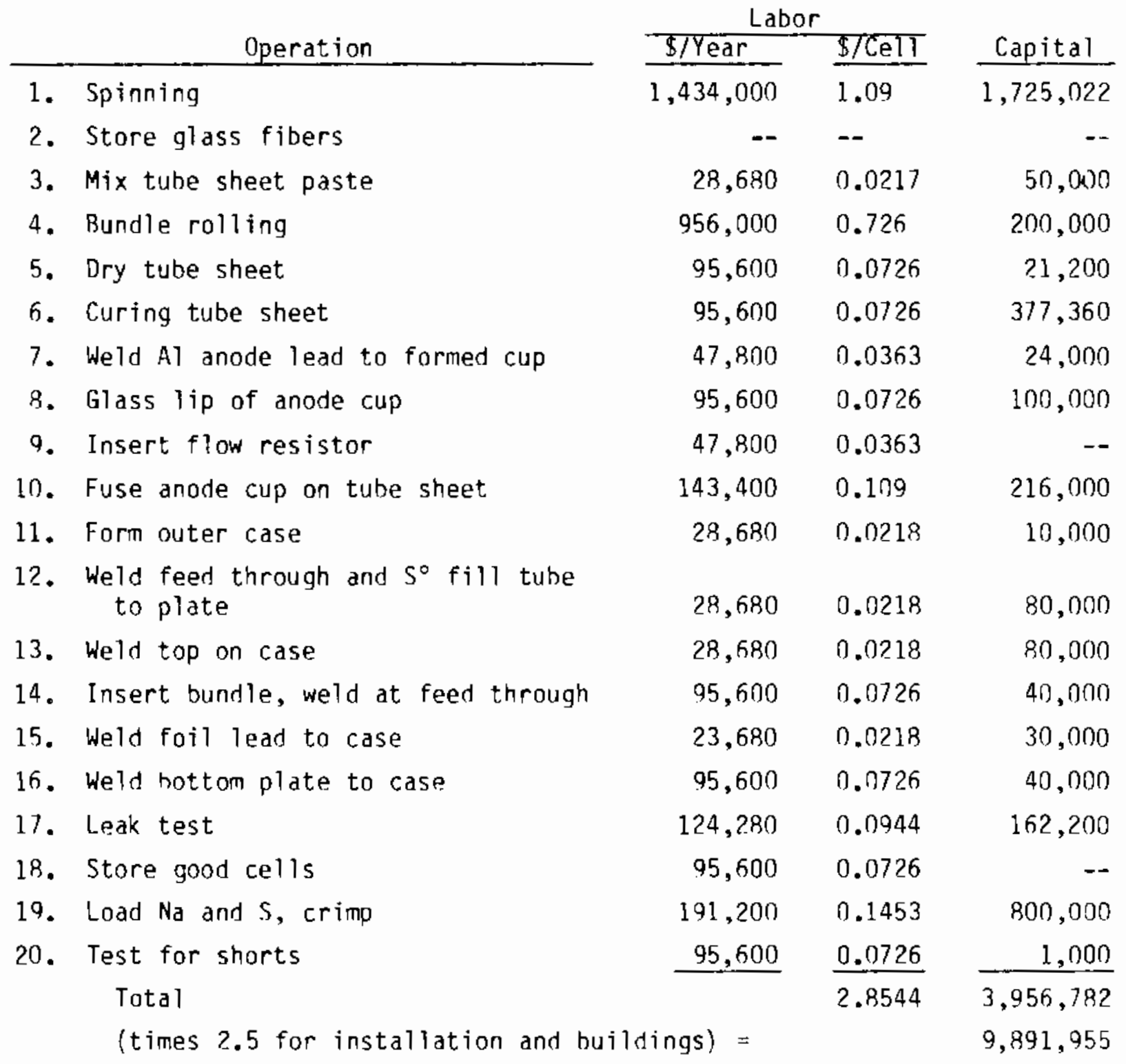


TABLE B.11. Levine (1981) Manufacturing Cost Estimate Summary of Costs - Double Al Can Cell

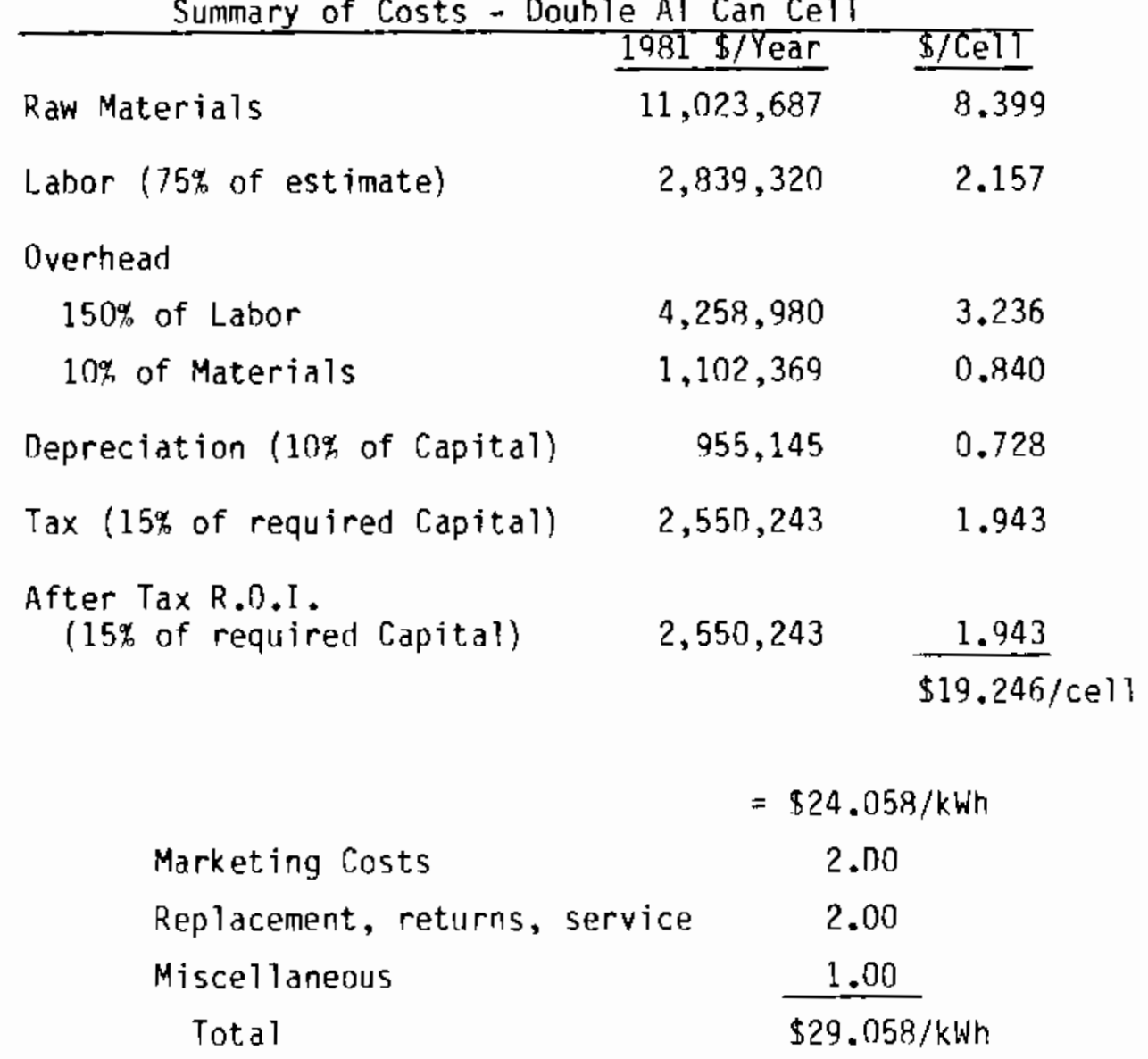


TABLE 8.12. Levine (1981) Raw Material Costs ... Double Al Can Cell

\begin{tabular}{|c|c|c|c|}
\hline Material & $\$ /$ Unit & Amount/Cell & $\$ / \mathrm{Cell}$ \\
\hline Sodium, ib & 1.00 & 1.0435 & 1.044 \\
\hline Sulfur, to & 0.10 & 2.5735 & 0.257 \\
\hline Glass for fibers, ib & 3.30 & 0.1629 & 0.537 \\
\hline Al lay-down tape, 1b & 3.84 & 0.0645 & 0.248 \\
\hline Mo coated foil, ea & 1.493 & 1.05 & 1.567 \\
\hline Al spacer tape, 1b & 3.72 & 0.2325 & 0.865 \\
\hline Glass for tube sheet, $1 \mathrm{~b}$ & 3.85 & 0.3944 & 1.519 \\
\hline A1 mandrel, $1 \mathrm{~b}$ & 2.50 & 0.0239 & 0.060 \\
\hline Al anode cup, ea & 0.24 & 1.05 & 0.252 \\
\hline A1 anode lead, 1b & 2.70 & 0.0198 & 0.053 \\
\hline Al flow restrictor, ea & 0.33 & 1.05 & 0.347 \\
\hline Al cathode cup, ea & 0.765 & 1.05 & 0.803 \\
\hline Cumene, Ib & 0.25 & 0.0404 & 0.010 \\
\hline Zn alloy, 9 & 0.18 & 1.05 & 0.189 \\
\hline Cup dip glass, ib & 3.85 & 0.1146 & 0.442 \\
\hline Cathode bottom cap, ea & 0.181 & 1.05 & 0.190 \\
\hline \multirow[t]{2}{*}{ Mandrel extension, ea } & 0.015 & 1.05 & 0.016 \\
\hline & & & $\$ 8.399$ \\
\hline
\end{tabular}


TABLE B.13. Levine (1981) Labor and Capital Breakdown ... Double A1 Can Cell

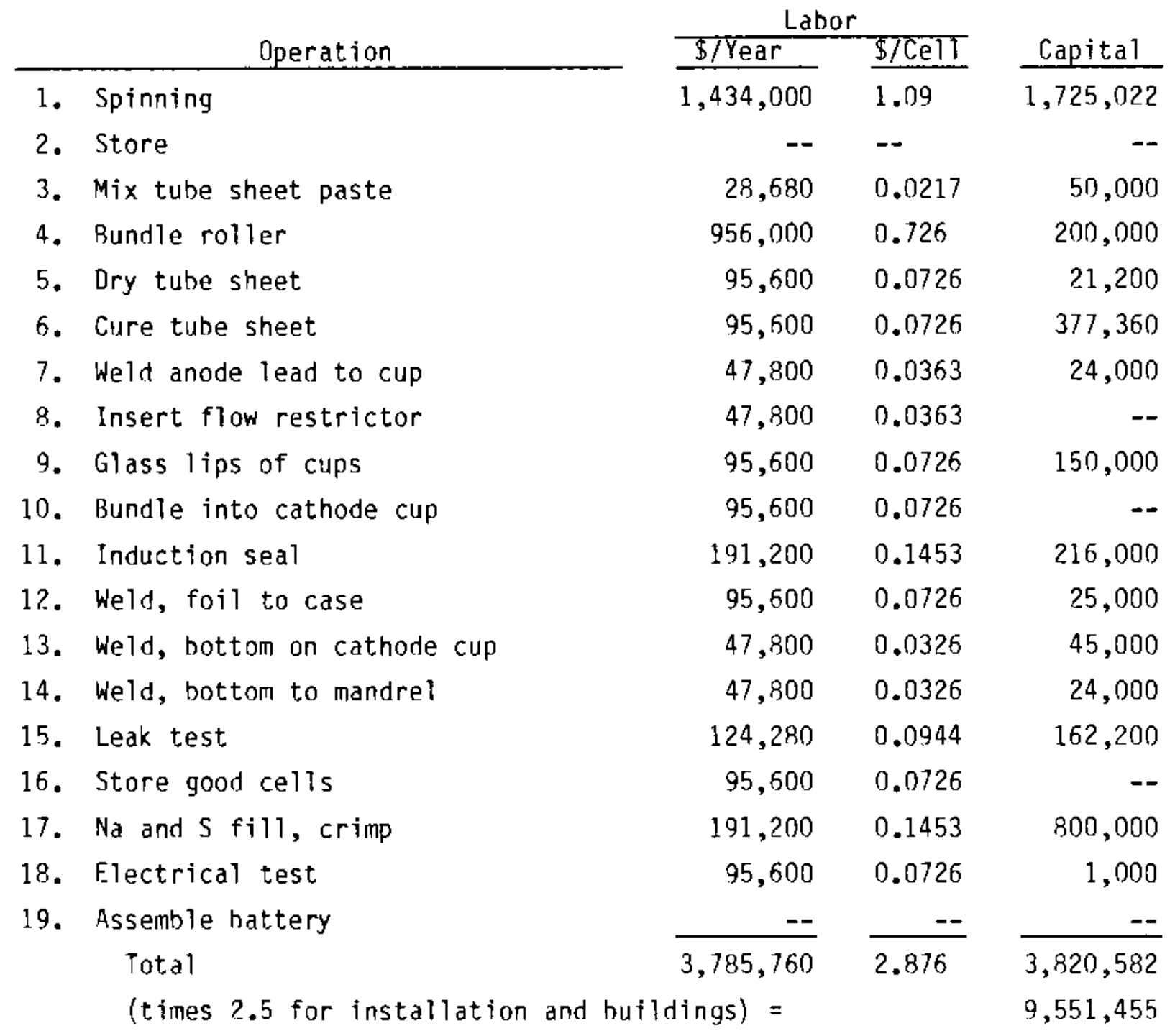


TABLE B.14. Wicker (1981) Raw Materials Required

for Production of 100 Tubes by

Isostatic Pressing

\begin{tabular}{|c|c|c|}
\hline & B-Alumina & B"-ATumina \\
\hline$\alpha-A$ Tumina & $21.07 \mathrm{~kg}$ & $21.03 \mathrm{~kg}$ \\
\hline Sodium carbonate & $3.65 \mathrm{~kg}$ & $3.45 \mathrm{~kg}$ \\
\hline Lithium carbonate & -- & $0.40 \mathrm{~kg}$ \\
\hline
\end{tabular}

TABLE 8.15. Wicker (1981) Raw Materials Qequired for Production of 100 Tubes by Electrophoretic Deposition Followed by isostatic Pressing

Alpha alumina

B-Alumina

Sodium carbonate

$16.00 \mathrm{~kg}$

Methlpropylketone (a) (MPK)

$2.78 \mathrm{~kg}$

$1.60 \mathrm{~L}$

(a) Assuming that $95 \%$ of the MPK is recovered.

TARLE B.16. Wicker (1981) Labor for the Alternative Routes Studied

Powder

\begin{tabular}{|c|c|c|c|c|c|c|}
\hline Route & $\begin{array}{c}\text { Lahor } \\
\text { (man-hours) } \\
\end{array}$ & $\begin{array}{c}\text { Preparation } \\
(\%)\end{array}$ & $\begin{array}{c}\text { Shaping } \\
\quad(\%) \\
\end{array}$ & $\begin{array}{c}\text { Sintering } \\
(\%) \\
\end{array}$ & $\begin{array}{c}\text { Control } \\
(\%) \\
\end{array}$ & $\begin{array}{c}\text { Misce } 11 \text { aneous } \\
(\%)\end{array}$ \\
\hline H11 J1 M1 & 6.842 & 14.6 & 12.7 & 29.6 & 31.6 & 11.4 \\
\hline H11 J1 L1 & 8.902 & 11.2 & 9.8 & 45.9 & 24.2 & 8.8 \\
\hline $\mathrm{H} 12 \mathrm{~K} 1 \mathrm{Ml}$ & 7.898 & 13.7 & 23.4 & 25.7 & 27.3 & 9.8 \\
\hline HI2 Kl L1 & 9.958 & 10.9 & 18.5 & 41.1 & 21.7 & 7.8 \\
\hline
\end{tabular}

TABLE B.17. Wicker (1981) Cost of Materials for 100

B-Alumina Tubes by Production Route

$\frac{\text { Route }}{\text { H11 J1 M1 }}$

H11 J1 L1

H12 K1 MI

H12 K1 L1

$\frac{\text { Raw Materials }}{\$}$

13.2

18.5

18.5
Other Materials $\$$

147.7

292.7

147.7

292.7 
TABLE B.18. Wicker (1981) Equipment Costs and Floor Area for B-Alumina by Production Route

\begin{tabular}{|c|c|c|c|}
\hline \multirow[b]{2}{*}{ Routes } & \multicolumn{2}{|c|}{ Floor Area } & \multirow{2}{*}{$\begin{array}{c}\text { Investment } \\
\$ \text { Million }\end{array}$} \\
\hline & Square Meter & Square Feet & \\
\hline H11 J1 M1 & 13,200 & 142,000 & 31.5 \\
\hline H11 J1 L1 & 19,600 & 211,000 & 63.2 \\
\hline H1? Kl MI & 15,000 & 162,000 & 30.5 \\
\hline $\mathrm{H} 12 \mathrm{~K} 1 \mathrm{Ll}$ & 21,300 & 230,000 & 62.4 \\
\hline
\end{tabular}

TABLE B.19. Wicker (1981) Factory Cost for B-Alumina in U.S. \$ by Production Route

Materials and Purchased

\begin{tabular}{|c|c|c|c|c|c|c|c|}
\hline Route & Labor & $\begin{array}{l}\text { Purchased } \\
\text { Components }\end{array}$ & $\begin{array}{c}\text { on } \\
\text { Labor }\end{array}$ & $\begin{array}{c}\text { on } \\
\text { Materials } \\
\end{array}$ & $\begin{array}{l}\text { Equipment } \\
\text { Depreciation }\end{array}$ & Rent & $\begin{array}{c}\text { Factory } \\
\text { Cost }\end{array}$ \\
\hline H11 J1 M1 & 91.30 & 214.5 & 136.95 & 21.45 & 49.22 & 8.88 & 522.30 \\
\hline H11 J1 L1 & 118.70 & 407.9 & 178.05 & 40.79 & 98.75 & 13.19 & 857.38 \\
\hline H12 K1 M1 & 105.30 & 221.6 & 157.95 & 22.16 & 47.66 & 10.13 & 564.80 \\
\hline $\mathrm{H} 12 \mathrm{~K} 1 \mathrm{~L} 1$ & 132.80 & 415.0 & 199.20 & 41.50 & 97.50 & 14.38 & 900.38 \\
\hline
\end{tabular}

TABLE 8.20. Wicker (1981) Selling Prices of 100 B-A Tumina Tubes by Production Route

$\frac{\text { Route }}{\text { H11 J1 M1 }}$

H11 J1 L1

H12 K1 Ml

H12 K1 Ll

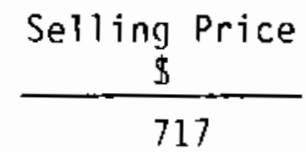

1,231

759

1,274 
TABLE B.21. Wicker (1981) Cell Weight Characteristics

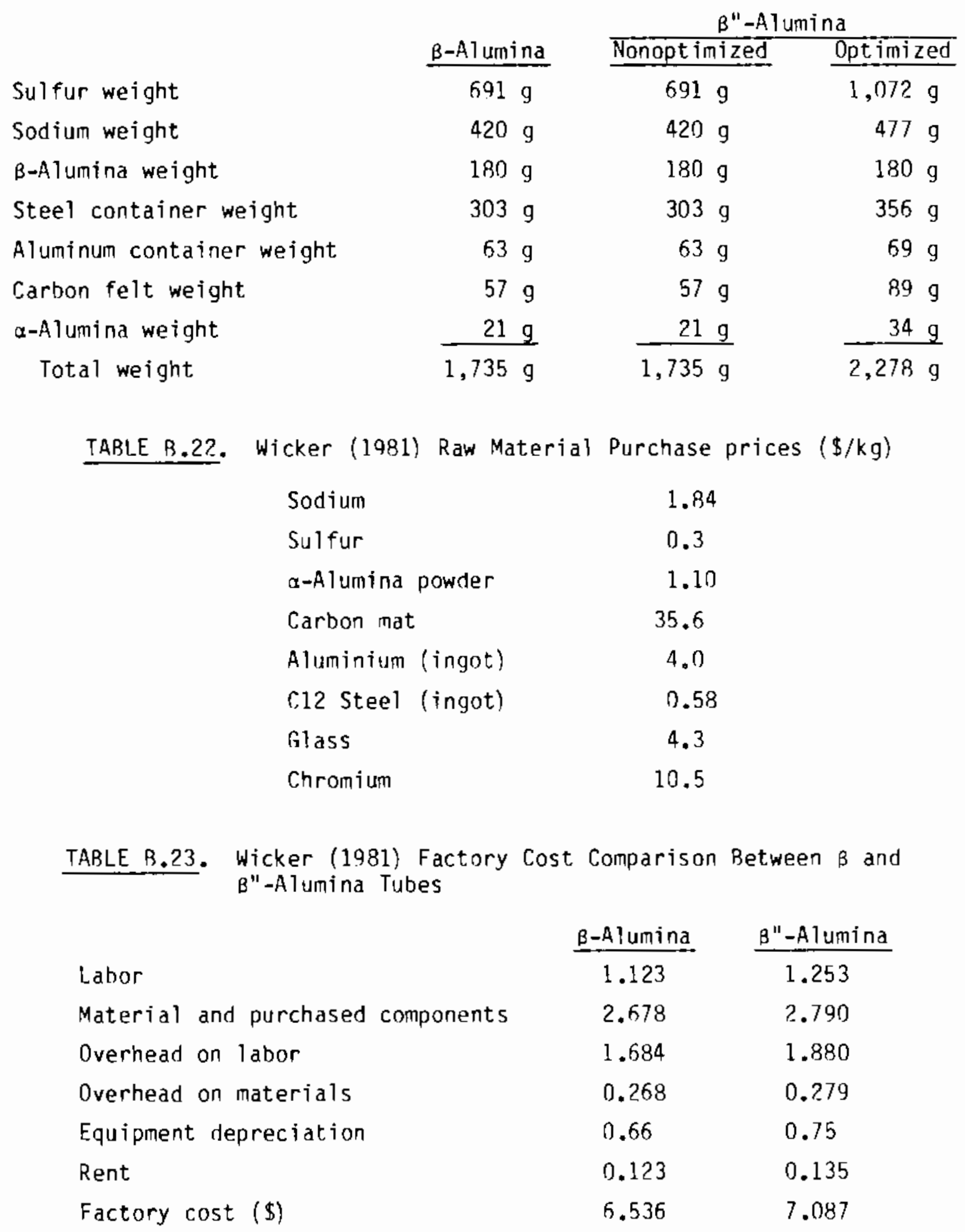


TABLE B.24. Wicker (1981) Cell Factory Cost Comparison - by Components

\begin{tabular}{|c|c|c|c|}
\hline $\begin{array}{l}\text { Labor Cost + Materials Cost }+ \\
\text { Overhead on Labor and Materials }\end{array}$ & $\begin{array}{l}\text { B-Alumir } \\
\text { Cell } \\
\end{array}$ & $\begin{array}{c}\text { Nonoptimized } \\
\beta^{\prime \prime}-A 1 \text { lumina } \\
\text { Cel1 }\end{array}$ & $\begin{array}{l}\text { Optimized } \\
\text { B"-Alumina }^{\prime \prime} \text { Cell } \\
\end{array}$ \\
\hline$\alpha-A 1$ umina & 0.267 & 0.267 & 0.343 \\
\hline Glass seat & 0.260 & 0.260 & 0.261 \\
\hline Sodium and filling & 1.034 & 1.034 & 1.163 \\
\hline Sulfur and fillng & 0.382 & 0.382 & 0.523 \\
\hline Graphite and electrode fabricatio & 2.463 & 2.520 & 3.822 \\
\hline Steel container + chrome plating & 1.489 & 1.489 & 1.689 \\
\hline Aluminium container & 0.336 & 0.336 & 0.367 \\
\hline Thermo-compression & 0.438 & 0.511 & 0.511 \\
\hline Quality control and tests & 0.540 & 0.581 & 0.589 \\
\hline Others & 0.175 & 0.177 & 0.212 \\
\hline Total $(\$)$ & 7.384 & 7.557 & 9.48 \\
\hline Equipment depreciation & 0.57 & 0.58 & 0.73 \\
\hline Rental cost & 0.57 & 0.58 & 0.73 \\
\hline $\begin{array}{l}\text { Factory cost for cell assembly } \\
\text { and tests }\end{array}$ & 8.52 & 8.72 & 10.9 \\
\hline Factory cost of $\beta$ or $\beta^{\prime \prime}$-alumina & 6.863 & 7.44 & 7.44 \\
\hline Cell factory cost $(\$)$ & 15.38 & 16.16 & 18.3 \\
\hline Cell factory cost $(\$ / k W h)$ & 37.7 & 37.5 & 35.0 \\
\hline \multirow[t]{2}{*}{ TABLE B.25. Wicker (1981) Cell } & Factory Cost & Comparison by Fin & cial Category \\
\hline & $\begin{array}{c}\text { B-Alumina } \\
\text { Cell } \\
\end{array}$ & $\begin{array}{l}\text { Nonopt imized } \\
\text { B"-Alumina } \\
\text { Cell } \\
\end{array}$ & $\begin{array}{l}\text { Optimized } \\
\beta^{\prime \prime} \text {-Alumina } \\
\text { Cell } \\
\end{array}$ \\
\hline Labor & 2.133 & 2.338 & 2.375 \\
\hline Materials & 7.358 & 7.476 & 9.137 \\
\hline Overhead on labor & 3.199 & 3.506 & 3.562 \\
\hline Overhead on materials & 0.736 & 0.748 & 0.914 \\
\hline Equipment depreciation & 1.263 & 1.367 & 1.516 \\
\hline Rental cost & 0.699 & 0.722 & 0.859 \\
\hline Cell factory cost $(\$)$ & 15.38 & 16.16 & 18.33 \\
\hline Cell factory cost $(\$ / \mathrm{kWh})$ & 37.7 & 37.5 & 35.0 \\
\hline
\end{tabular}


TABLE B.26. Wicker (1981) Module Factory Cost Comparison - by Components

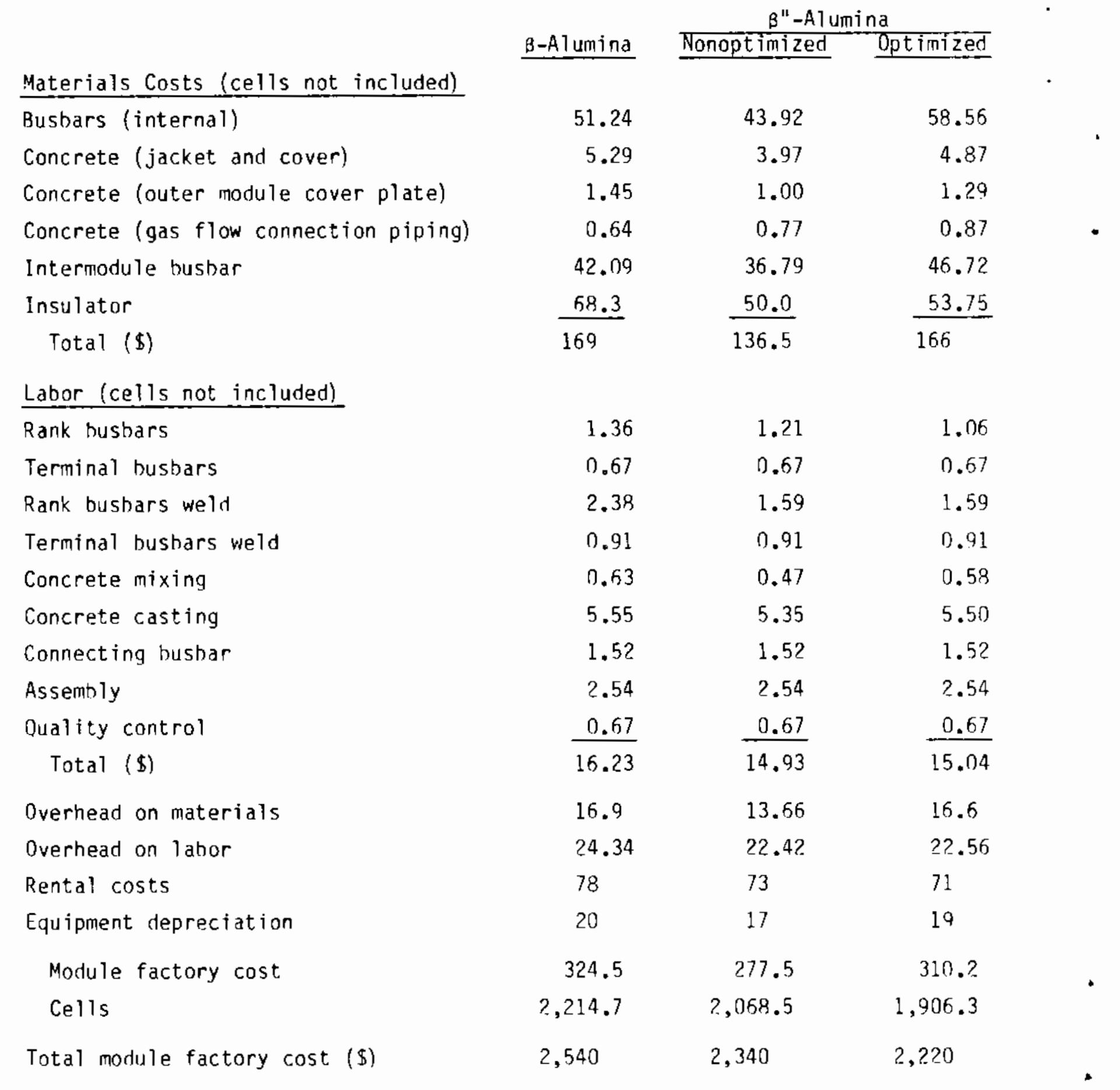


TABLE B.27. Wicker (1981) Module Factory Costs Comparison by Financial Category

\begin{tabular}{|c|c|c|c|}
\hline & & $B "-A \mid L$ & \\
\hline & B-Alumina & Nonoptimized & Optimized \\
\hline Material costs & $1,228.5$ & $1,093.4$ & $1,116.2$ \\
\hline Labor & 323.4 & 314.2 & 262.0 \\
\hline Overhead on materials & 122.8 & 109.3 & 111.6 \\
\hline Overhead on labor & 485.1 & 471.3 & 393.1 \\
\hline Rental costs & 178.7 & 161.3 & 161.5 \\
\hline Equipment depreciation & 202 & 192 & 177 \\
\hline Module factory cost (\$) & 2,540 & 2,340 & 2,220 \\
\hline Nominal energy & $50 \mathrm{kwh}$ & $47.06 \mathrm{kWh}$ & $45.87 \mathrm{kWh}$ \\
\hline Module factory cost $(\$ / \mathrm{kWh})$ & 50.8 & 49.7 & 48.4 \\
\hline
\end{tabular}

TABLE B.28. Wicker (1981) Balance of System Cost Estimate

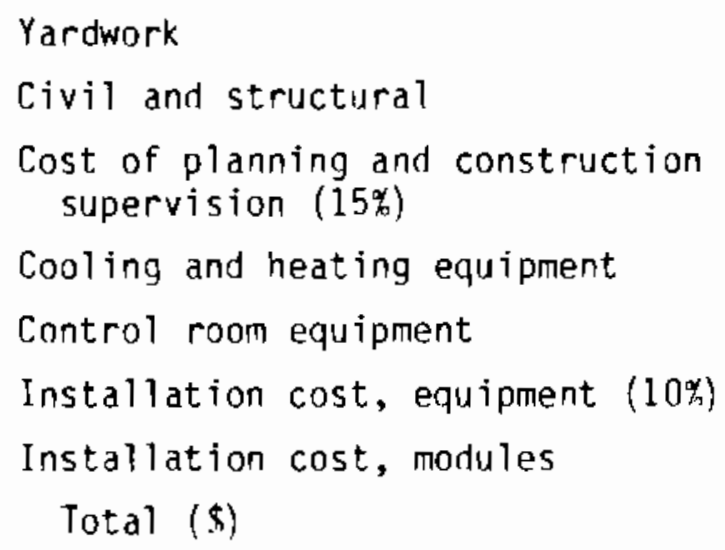

$\begin{array}{rr}\frac{\text { B-Alumina }}{90,000} & \frac{\text { B"-Alumina }}{90,000} \\ 190,000 & 185,000 \\ 42,000 & 41,000 \\ 675,000 & 425,000 \\ 150,000 & 150,000 \\ 82,000 & 50,000 \\ 210,000 & \frac{210,000}{1,151,000}\end{array}$


TABLE B.29. Wicker (1981) Total Battery Cost (\$ million)

\begin{tabular}{|c|c|c|c|}
\hline & \multirow[b]{2}{*}{ B-Alumina } & \multicolumn{2}{|c|}{ B" Alumina } \\
\hline & & Nonoptimized & Optimized \\
\hline 100 MWh modules factory cost & 5.12 & 5.25 & 4.89 \\
\hline Taxes & 0.84 & 0.88 & 0.80 \\
\hline After taxes return on investment & 0.84 & 0.88 & 0.80 \\
\hline Battery selling price & 6.80 & 7.01 & 6.49 \\
\hline Plant cost & 1.44 & 1.15 & 1.15 \\
\hline Contingency on plan cost $(20 \%)$ & 0.29 & 0.23 & 0.23 \\
\hline Marketing, Warranty, Miscellaneous cost & 0.50 & 0.50 & 0.50 \\
\hline Total & 9.03 & 8.89 & 8.37 \\
\hline$\$ / \mathrm{kWh}$ & 90.3 & 88.9 & 83.7 \\
\hline
\end{tabular}

PNL Note: The battery selling price and marketing, warranty, and miscellaneous expenses were added to estimate a total manufactured cost estimate. The cost for the optimized beta"-alumina battery of $\$ 69.90 / \mathrm{kWh}(1980 \$)$ was inflated to $\$ 87 / \mathrm{kWh}(1984 \$)$. The total installed system cost of $\$ 83.71 \mathrm{kWh}(1980$ \$) was inflated to $\$ 104 / \mathrm{kWh}(1984 \$)$. 
TABLE B.30. Wicker (1981) Detailed Comparison Between $\beta$ and B"-Alumina

\begin{tabular}{|c|c|c|c|c|}
\hline \multirow[b]{2}{*}{ Cell Weight Parameters } & \multicolumn{2}{|c|}{$B-A 1$ umina } & \multicolumn{2}{|c|}{ B"-Alumina } \\
\hline & $\mathrm{kg}$ & $\mathrm{kg} / \mathrm{kWh}$ & & $\mathrm{kg} / \mathrm{kWh}$ \\
\hline Sulfur & 0.691 & 1.693 & 1.072 & 2.050 \\
\hline Sodium & 0.420 & 1.029 & 0.477 & 0.912 \\
\hline B-Alumina & 0.180 & 0.441 & 0.180 & 0.344 \\
\hline Steel container & 0.303 & 0.743 & 0.356 & 0.681 \\
\hline Aluminum container & 0.063 & 0.154 & 0.069 & 0.132 \\
\hline Carbon felt & 0.057 & 0.140 & 0.089 & 0.170 \\
\hline Other & 0.027 & 0.051 & 0.035 & 0.067 \\
\hline Total & 1.735 & 4.252 & 2.278 & 4.356 \\
\hline Cell Cost Parameters & $\$$ & $\$ / \mathrm{kWh}$ & $\$$ & $\$ / \mathrm{kWh}$ \\
\hline Alumina (material and labor) & 6.040 & 14.80 & 6.512 & 12.45 \\
\hline Equipment depreciation on alumina & 0.693 & 1.70 & 1.434 & 2.74 \\
\hline Rental costs on alumina & 0.129 & 0.32 & 0.129 & 0.25 \\
\hline B-Alumina factory cost & 6.862 & 16.82 & 8.075 & 15.44 \\
\hline Sulfur & 0.382 & 0.936 & 0.523 & 1.000 \\
\hline Sodium & 1.034 & 2.534 & 1.163 & 2.224 \\
\hline Steel container & 1.489 & 3.649 & 1.689 & 3.229 \\
\hline Aluminum container & 0.336 & 0.824 & 0.367 & $0: 702$ \\
\hline Carbon felt & 2.463 & 6.037 & 3.822 & 7.308 \\
\hline Thermo-compression & 0.438 & 1.073 & 0.511 & 0.977 \\
\hline Quality control and tests & 0.540 & 1.324 & 0.589 & 1.126 \\
\hline Other & 0.702 & 1.720 & 0.816 & 1.560 \\
\hline $\begin{array}{l}\text { Equipment depreciation on cell } \\
\text { fabrication }\end{array}$ & 0.57 & 1.40 & 0.73 & 1.40 \\
\hline Rental costs on cell fabrication & 0.57 & 1.40 & 0.73 & 1.40 \\
\hline Cell factory cost & 15.38 & 37.7 & 18.33 & 35.0 \\
\hline
\end{tabular}


TABLE B.30. Wicker (1981) Detailed Comparison Between B and B"-Alumina (contd)

\begin{tabular}{|c|c|c|c|c|}
\hline \multirow[b]{2}{*}{ Module Weight Parameters } & \multicolumn{2}{|c|}{ B-Alumina } & \multicolumn{2}{|c|}{$B^{\prime \prime}-A$ lumina } \\
\hline & $\mathrm{kg}$ & $\mathrm{kg} / \mathrm{kwh}$ & $\mathrm{kg}$ & $\mathrm{kg} / \mathrm{kw} / \mathrm{h}$ \\
\hline Cells & 250.0 & 5.0 & 237.0 & 5.17 \\
\hline Busbars & 28.0 & 0.56 & 32.0 & 0.70 \\
\hline Concrete and other & 228.0 & 4.56 & 210.0 & 4.58 \\
\hline Total & 506.0 & 10.1 & 479.0 & 10.4 \\
\hline Module Cost Parameters & $\$$ & $\$ / \mathrm{kWh}$ & $\$$ & $\$ / \mathrm{kWh}$ \\
\hline Cell factory cost & $2,215,0$ & 44.3 & $1,906.0$ & 41.6 \\
\hline Busbar material and labor & 116.0 & 2.3 & 126.0 & 2.7 \\
\hline Concrete & 24.0 & 0.5 & 23.0 & 0.5 \\
\hline Assembly, control, other & 87.0 & 1.7 & 71.0 & 1.5 \\
\hline Rental costs & 78.0 & 1.6 & 71.0 & 1.5 \\
\hline Equipment depreciation & 20.0 & 0.4 & 19.0 & 0.4 \\
\hline Module factory cost & $2,540.0$ & 50.8 & $2,220.0$ & 48.4 \\
\hline Taxes and return & 832.0 & 16.6 & 730.0 & 16.0 \\
\hline Module selling price & $3,372.0$ & 67.4 & $2,950.0$ & 64.4 \\
\hline 100-Mwh Unit & Million & $\$ / \mathrm{k}$ lh & $\begin{array}{c}\$ \\
M i l l i o n \\
\end{array}$ & $\$ / \mathrm{kWh}$ \\
\hline Battery selling price & 6.80 & 68.0 & 6.49 & 64.9 \\
\hline Plant cost and contingency & 1.73 & 17.3 & 1.38 & 13.8 \\
\hline Marketing, warranty, ... & 0.50 & 5.0 & 0.50 & 5.0 \\
\hline Total 100-MWh unit price & 9.03 & 90.3 & 8.37 & 83.7 \\
\hline
\end{tabular}


TABLE R.31. Roberts (1984a) Factory Cost Per Year (mid-1982 \$)

Cost/Year

Capital Equipment

Total Investment

$\$ 34,319,010$

Yearly Amortization at $10 \% /$ Year

$\$ 3,432,000$

Installation and Freight Charges

Total Charges at $25 \%$ of Capital Equipment $\$ 8,580,000$

Yearly Charges at 10\%/Year

$\$ 858,000$

Materials

Direct

$\$ 85,542, n 00$

Overhead at $10 \%$ of Direct

$\$ 8,554,000$

Labor

Direct at $\$ 10 /$ man-hour

$\$ 11,042,000$

Dverhead at $150 \%$ of Direct

$\$ 16,563,000$

Rent

Charge at $\$ 5 / \mathrm{ft}^{2}$-year

$\$ 1,100,000$

Factory Cost/Year

$\$ 127,091,000$

Factory Cost/Rattery at 25 Batteries/Year

$\$ 5,084,000$ 
TABLE B.32. Roberts (1984a) Selling Price Per Battery (mid-1982 \$)

Factory Cost/Battery

$\$ 5,084,000$

Return on Investment (ROI) Base

Working Capital/Battery at $30 \%$ of Factory Cost

$\$ 1,525,000$

Investment/Battery (Captital Cost plus Installation Charges)

$\$ 1,716,000$

Base for ROI

$\$ 3,241,000$

ROE (after tax) at 15\% of Base

$\$ 486,000$

Taxes at $15 \%$ of Base

$\$ 486,000$

Marketing, Engineering, Warranty, Service

$\$ 500,000$

Selling Price/Battery

$\$ 6,556,000$

Selling Price/kWh

$\$ 66$

Selling Price/kW

$\$ 330$

PNL Note: The manufactured selling price of $\$ 66 / \mathrm{kWh}(1982 \$)$ was inflated to $\$ 71 / \mathrm{k}$ Wh $(1984 \$)$. 
TABLE B.33. Bechtel (1982) Manufacturing Cost Estimate

Factory Price Estimate - Sodium-Sulfur Battery

\begin{tabular}{|c|c|c|}
\hline & \multicolumn{2}{|c|}{$1980 \$ / k_{W h}(\mathrm{a})$} \\
\hline & Low & $\mathrm{High}(\mathrm{b})$ \\
\hline Labor (Direct + 150\% Overhead) & 27.49 & - \\
\hline Materials (Materials $+10 \%$ Overhead) & 43.24 & -- \\
\hline Energy & 2.82 & - \\
\hline Depreciation & 3.60 & - \\
\hline Rent & 1.17 & $-\infty$ \\
\hline Factory Cost & 78.32 & - \\
\hline After Tax ROI (15\%) & 8.92 & -- \\
\hline Taxes (15\% of Investment) & 8.92 & - \\
\hline Marketing, Warranty, and Miscellaneous & 5.00 & - \\
\hline FOB Factory Price & 101.16 & 127.46 \\
\hline \multirow[t]{3}{*}{ Manufacturing Plant Assumptions } & \multirow{2}{*}{\multicolumn{2}{|c|}{$1980 \$ \times 10^{3}$}} \\
\hline & & \\
\hline & Low & $\underline{H i g h}(h)$ \\
\hline Equipment (Including $25 \%$ Installation) & 89,929 & - \\
\hline Working Capital $(30 \%$ of Factory Cost) & 58,740 & -- \\
\hline Total Plant Investment & 148,669 & -- \\
\hline Init Capacity, kWh & & \\
\hline Production Volume, MWh/yr & & \\
\hline Factory Floor Space, $\mathrm{ft}^{2}$ & & \\
\hline
\end{tabular}

(a) The kwh hase is for end-of-life energy capacity.

(b) Data for high estimate was not available. A high value of $\$ 127.46 / \mathrm{kWh}$ was obtained by multiplying the low estimate by 1.26 , as explained in the text.

PNL Note: The manufactured cost estimates of $\$ 101.16$ to $\$ 127.46 / \mathrm{kWh}(1980 \$)$ were inflated to $\$ 126$ to $\$ 159 / \mathrm{kWh}(1984 \$)$. 
TABLE B.34. Bechtel (1982) Balance of System Installed Cost Estimate Battery: Sodium-Sulfur

Application: Multiple Residence.

\begin{tabular}{|c|c|c|c|c|c|c|c|}
\hline \multirow[b]{2}{*}{ System/Component } & \multirow[b]{2}{*}{ Hours } & \multicolumn{3}{|c|}{ Costs $(1980 \$)$} & \multicolumn{3}{|c|}{ Cost Distribution } \\
\hline & & Labor & Material & Subtotal & $\$$ & $\$ / \mathrm{kW}$ & $\$ / \mathrm{kwh}$ \\
\hline Battery & & & & & & & \\
\hline Shipping (500 miles) & - & -- & - & 680 & -- & -- & 1.06 \\
\hline Installation & 74 & 1,330 & -- & 1,330 & 860 & $\ldots$ & 0.73 \\
\hline
\end{tabular}

Building

Land

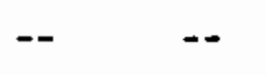

720

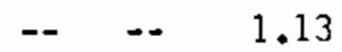

Therma? Management

Heating Subsystem

Thermal Housing

$\begin{array}{rrr}100 & 1,800 & -- \\ 42 & 760 & 1,240 \\ 23 & 410 & 940\end{array}$

1,800

$-\quad-2.81$

other

2,000

-- -3.13

Instrument ation

Smoke Detection

$10 \quad 180$

400

580

$15 \quad 270$

230

500

-- $--\quad 1.95$

Other

1

Electrical

DC Wiring

DC Equipment

$\begin{array}{rrr}28 & 500 & 2,240 \\ 14 & 250 & 2,580 \\ 25 & 450 & 310 \\ 6 & 110 & 80 \\ 3 & 50 & 100\end{array}$

2,740

-- - 4.28

AC Wiring

(a)

AC Panel Requirements

other

Auxiliaries

Fire Extinguisher

Subtotals

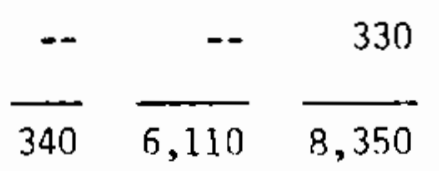

$\begin{array}{rrrrr}330 & 330 & \cdots & \cdots \\ 15,860 & & 2,270 & 0 & 21.23 \\ 15,860 & 2,270 & 0 & 21.20 \\ 3,360 & 480 & 0 & 4.50 \\ 19,220 & 2,750 & 0 & 25.70\end{array}$


TABLE B.35. Bechtel (1982) Total Installed System Costs

Rattery: Sodium-Sulfur

Application: Multiple Residence

\begin{tabular}{|c|c|c|c|c|c|c|c|c|}
\hline \multirow{2}{*}{$1+e m$} & \multicolumn{4}{|c|}{ Low Estimate } & \multicolumn{4}{|c|}{ HIgh Estimate } \\
\hline & $\begin{array}{l}\text { Total Cost } \\
5\end{array}$ & $\frac{\operatorname{Cost} D}{5}$ & \multicolumn{2}{|c|}{$\frac{\text { IstributIon }}{\delta / \mathrm{kW} \quad \$ / \mathrm{kWh}}$} & $\begin{array}{c}\text { Total } \operatorname{Cos} t \\
5\end{array}$ & \multicolumn{3}{|c|}{ Cost Distribution } \\
\hline Battery, $\mathrm{FOB}(\mathrm{a})$ & 64,640 & 0 & 0 & $10 ?$ & 81,280 & 0 & 0 & 127 \\
\hline BOS, Field Cost ${ }^{(b)}$ & 11,530 & $.1,650$ & $\therefore$ & 15 & 23,060 & 3,300 & $\underline{0}$ & 31 \\
\hline Total Field Cost & 76,170 & 1,650 & 0 & 116 & 104,340 & 3,300 & 0 & 158 \\
\hline Engineering Costs (15x) & 11,430 & 250 & $\underline{0}$ & 17 & 15,650 & 500 & $\stackrel{0}{-}$ & 24 \\
\hline Subtotal & 87,600 & 1,900 & 0 & 133 & 119,990 & 3,800 & 0 & 182 \\
\hline Contingency (208) & 17,520 & 380 & $\underline{0}$ & 27 & $.24,000$ & 760 & $\underline{0}$ & 36 \\
\hline Total Installed cost & 105,120 & 2,280 & 0 & 160 & 143,990 & 4,560 & 0 & 218 \\
\hline $\begin{array}{l}\text { (a) From Table } 8.33 \text { us } \\
\text { (b) From Table } 8.34 \text {. }\end{array}$ & $=1.2 \times$ & $\begin{array}{l}(r a+\theta d) \\
\text { id Cost }\end{array}$ & $\begin{array}{l}\text { capaci } \\
+; \text { Low }\end{array}$ & ty. & leld Cost. & & & \\
\hline PNL Note: $\begin{array}{l}\text { Installed sy } \\
272 / \mathrm{kwh}(198\end{array}$ & $\cos t \theta$ & es & 150 & $218 / k$ & $(1980 \$) *$ & a inflat & ted to & 6199 to \\
\hline
\end{tabular}


TABLE B.36. Bechtel (1982) Low Life-Cycle Cost Estimate

Life-Cycle Cost Analys is (1980 \$)

Battery Type: Sodium-Sulfur (Ford) Application Type: Multiple Residence

Low Estimate Input Parameters

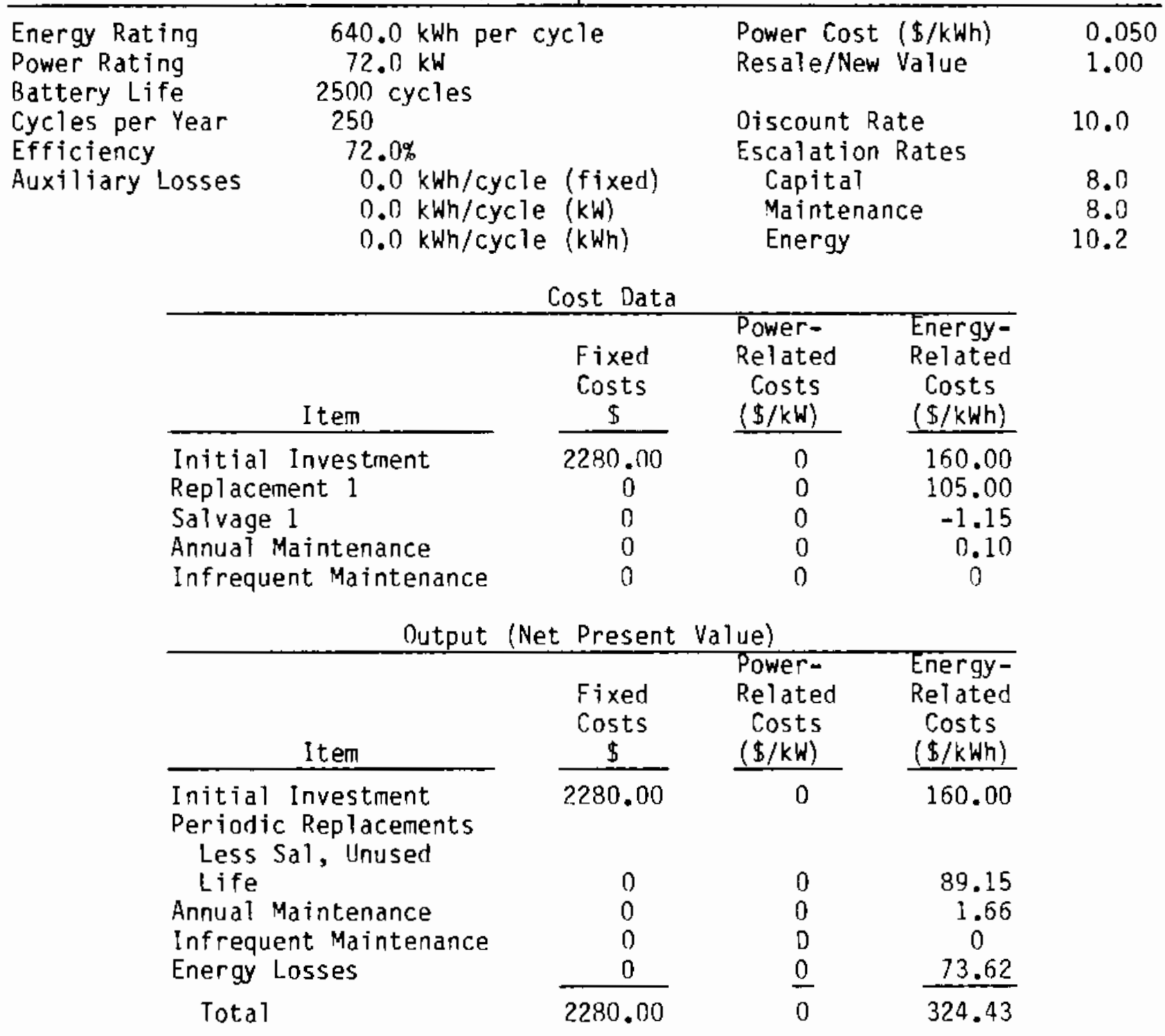

Total System Life-Cycle Cost: $\$ 210,000$

PNL Note: The life-cycle cost of $\$ 324.43 / \mathrm{kWh}(1980 \$)$ was inflated to $\$ 404 / \mathrm{kWh}$ (1984 \$). 
TABLE B.37. Bechtel (1982) High Life-Cycle Cost Estimate

Life-Cycle Cost Analysis (1980 \$)

Battery Type: Sodium-Sulfur (Ford) Application Type: Multiple Residence

High Estimate Input Parameters

\begin{tabular}{lclr}
\hline Energy Rating & $640.0 \mathrm{kWh}$ per cycle & Power Cost $(\$ / \mathrm{kWh})$ & 0.050 \\
Power Rating & $72.0 \mathrm{~kW}$ & Resale/New Value & 1.00 \\
Battery Life & $2000 \mathrm{cycles}$ & & \\
Cycles per Year & 250 & Discount Rate & 10.0 \\
Efficiency & $66.0 \%$ & Escalation Rates & \\
Auxiliary Losses & $0.0 \mathrm{kWh} /$ cycle (fixed) & Capital & 8.0 \\
& D.0 kWh/cycle (kW) & Maintenance & 8.0 \\
& $0.0 \mathrm{kWh} /$ cycle (kWh) & Energy & 10.2
\end{tabular}

Cost Data

\begin{tabular}{|c|c|c|c|}
\hline I tem & $\begin{array}{c}\text { Fixed } \\
\text { Costs } \\
\$ \\
\end{array}$ & $\begin{array}{l}\text { Power- } \\
\text { Related } \\
\text { Costs } \\
(\$ / \mathrm{kW}) \\
\end{array}$ & $\begin{array}{l}\text { Energy- } \\
\text { Related } \\
\text { Costs } \\
(\$ / \mathrm{kWh}) \\
\end{array}$ \\
\hline $\begin{array}{l}\text { Initial Investment } \\
\text { Replacement } 1 \\
\text { Salvage } 1 \\
\text { Annual Maintenance } \\
\text { Infrequent Maintenance }\end{array}$ & $\begin{array}{c}4560.00 \\
0 \\
0 \\
0 \\
0\end{array}$ & $\begin{array}{l}0 \\
0 \\
0 \\
0 \\
0\end{array}$ & $\begin{array}{c}218.00 \\
136.00 \\
-2.31 \\
0.14 \\
0\end{array}$ \\
\hline \multicolumn{4}{|c|}{ Butput (Net Present Value) } \\
\hline Item & $\begin{array}{c}\text { Fixed } \\
\text { Costs } \\
\$\end{array}$ & $\begin{array}{l}\text { Power- } \\
\text { Related } \\
\text { Costs } \\
(\$ / \mathrm{kW}) \\
\end{array}$ & $\begin{array}{l}\text { Energy- } \\
\text { Related } \\
\text { Costs } \\
(\$ / \mathrm{kWh}) \\
\end{array}$ \\
\hline $\begin{array}{l}\text { Initial Investment } \\
\text { Periodic Replacements } \\
\text { Less Sal, Unused } \\
\text { Life } \\
\text { Annual Maintenance } \\
\text { Infrequent Maintenance } \\
\text { Energy Losses }\end{array}$ & 4560.00 & $\begin{array}{l}0 \\
0 \\
0 \\
0 \\
\end{array}$ & $\begin{array}{c}176.24 \\
2.32 \\
0 \\
86.31 \\
\end{array}$ \\
\hline Total & 4560.00 & 0 & 482.87 \\
\hline
\end{tabular}

Total System Life-Cycle Cost: $\$ 314,000$

PNL Note: The life-cycle cost of $\$ 482.87 / \mathrm{kWh}(1980 \$)$ was inflated to $\$ 602 / \mathrm{kWh}$ (1984 \$) . 
$+$

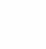


APPENOIX C

LEAD ACID BATTERY COST DETAILS 
APPENDIX C

LEAD ACID BATTERY COST DETAILS

The following pages present cost estimating details extracted from the sources reviewed for this study. The tahles have been reproduced to match the figures and notes presented in the original sources except for some minor modification to the format or style. Additional clarifying comments, if any, are designated as PNL Notes.

The data provide an indication of the completeness and level of detail found among the various estimates and also serve as a rudimentary data base of battery cost information. The supporting details presented in this appendix correspond to the cost estimates referenced in Tahles 5.2, 5.4, and 5.5. 


\section{TABLE C.1. Ferrel1 (1977) Manufacturing Cost Estimates}

Manufacturing Price Estimates for the VLL43 and VLL45 Cells Produced at 1000 MWh per Year

\begin{tabular}{|c|c|c|c|c|c|c|}
\hline Item & \multicolumn{2}{|c|}{$\begin{array}{cc}20 \mathrm{MW} & 60 \mathrm{MWh} \\
\text { Battery } & \mathrm{Cel} 1 \\
\text { (VLL43 } & \mathrm{HSG} \text { ) } \\
\$ / \mathrm{cell} & \$ / \mathrm{kWh}\end{array}$} & \multicolumn{2}{|c|}{$\begin{array}{l}20 \text { MW } 100 \text { MWh } \\
\text { Battery Cell } \\
\text { (VLL45 HSG) }\end{array}$} & \multicolumn{2}{|c|}{$\begin{array}{l}10 \mathrm{MW} 100 \mathrm{MWh} \\
\text { Battery Ce11 } \\
\text { (VLL45 LSG) }\end{array}$} \\
\hline \multicolumn{7}{|l|}{ Purchased Parts } \\
\hline Separators & 36.08 & 2.26 & 37.80 & 2.07 & 37.80 & 1.98 \\
\hline Jar and Cover Assembly & 101.00 & 6.32 & 101.00 & 5.54 & 101,00 & 5.30 \\
\hline Copper Inserts & 19.61 & 1.23 & 19.61 & 1.08 & 19.61 & 1.03 \\
\hline Other Parts & 108.18 & 6.77 & 112.30 & 6.16 & 112.30 & 5.90 \\
\hline Total & 264.87 & 16.58 & 270.71 & 14.85 & 270.21 & 14.21 \\
\hline Scrap and Freight on Parts & 13.21 & .83 & 13.50 &. .74 & 13.50 & .71 \\
\hline Total Purchased Parts & 278.08 & 17.41 & 284.21 & 15.59 & 284.21 & 14.92 \\
\hline Plate Grid and Active & 309.15 & 19.36 & 330.57 & 18.14 & 329.50 & 17.30 \\
\hline \multicolumn{7}{|l|}{ Materials and Terminals } \\
\hline Direct Labor & 45.12 & 2.83 & 47.22 & 2.59 & 47.22 & 2.48 \\
\hline Overhead, G\&A, Profit & $\underline{256.35}$ & $\underline{16.05}$ & $\underline{268.31}$ & 14.72 & 268.09 & 14.07 \\
\hline Selling Price & 888.70 & $\underline{5.65}$ & 930.31 & 51.03 & 929.02 & 48.77 \\
\hline Rated Energy (kWh) (h) & $15.97(3$ & h) & 18.23 & h) & 19.05 & h) \\
\hline Rated Depth of Discharge, $\%$ & 90 & & & & 8 & \\
\hline
\end{tabular}

Notes: 1. I.ead at $\$ 0.20$ per $1 \mathrm{~b}$; antimony at $\$ 2.00$ per $1 \mathrm{~b}$.

2. Scrap on purchased parts at $1.93 \%$.

3. Freight on purchased parts and scrap at 3.03 .

PNL Note: Manufactured cost estimates of $\$ 48.77-55.65 / \mathrm{kWh}(1977 \$$ ) were inflated to $\$ 77-88 / \mathrm{kWh}(1984 \$)$. 
IABLE C.2. Ferrell (1977) Salvage and Reuse Credits (20 $\$ / 1 \mathrm{~b}$ lead)

\begin{tabular}{|c|c|c|c|c|c|c|c|}
\hline Cell Component & $\begin{array}{l}\text { Reuse } \\
\text { Rate }\end{array}$ & $\begin{array}{l}20 \text { MW } 6 \\
\text { Battery } \\
\$ / \text { cell }\end{array}$ & $\begin{array}{l}0 \text { MWh } \\
\text { Cell } \\
\$ / \mathrm{kWh}\end{array}$ & $\begin{array}{l}20 \text { MW } 10 \\
\text { Battery } \\
\$ / \text { cell }\end{array}$ & $\begin{array}{l}0 \text { MWh } \\
\text { Cell } \\
\$ / k W h \\
\end{array}$ & $\begin{array}{l}10 \mathrm{MW} 100 \\
\text { Battery } \\
\$ / \text { cell }\end{array}$ & $\begin{array}{l}0 \text { MWh } \\
\text { Cell } \\
\$ / \text { kWh }\end{array}$ \\
\hline Plate and Terminal $\mathrm{Pb}$, Sb & $(0.8)$ & 243 & 15.22 & 260 & 14.26 & 260 & 13.65 \\
\hline Jar, Cover, Hoops & $(0.95)$ & 96 & 6.01 & 96 & 5.27 & 96 & 5.04 \\
\hline Terminal Copper & $(0.8)$ & 16 & 1.00 & 16 & 0.88 & 16 & 0.84 \\
\hline Other Cell Parts & & 10 & 0.62 & 10 & 0.55 & 10 & 0.53 \\
\hline Totals & & 365 & 22.85 & 382 & 20.96 & 382 & 20.06 \\
\hline Rated Output Energy, kWh & & \multicolumn{2}{|c|}{15.97} & \multicolumn{2}{|c|}{18.23} & \multicolumn{2}{|c|}{19.05} \\
\hline Original Parts and Material Cost & & \multicolumn{2}{|l|}{587} & \multicolumn{2}{|c|}{615} & \multicolumn{2}{|l|}{624} \\
\hline $\begin{array}{l}\text { Recovery of Original Parts and } \\
\text { Material Cost, } \%\end{array}$ & & \multicolumn{2}{|l|}{62} & \multicolumn{2}{|l|}{62} & \multicolumn{2}{|l|}{62} \\
\hline
\end{tabular}

Similarly, salvage and reuse credits were calculated for the case of 25 - and 30-cent lead. These credits are summarized below:

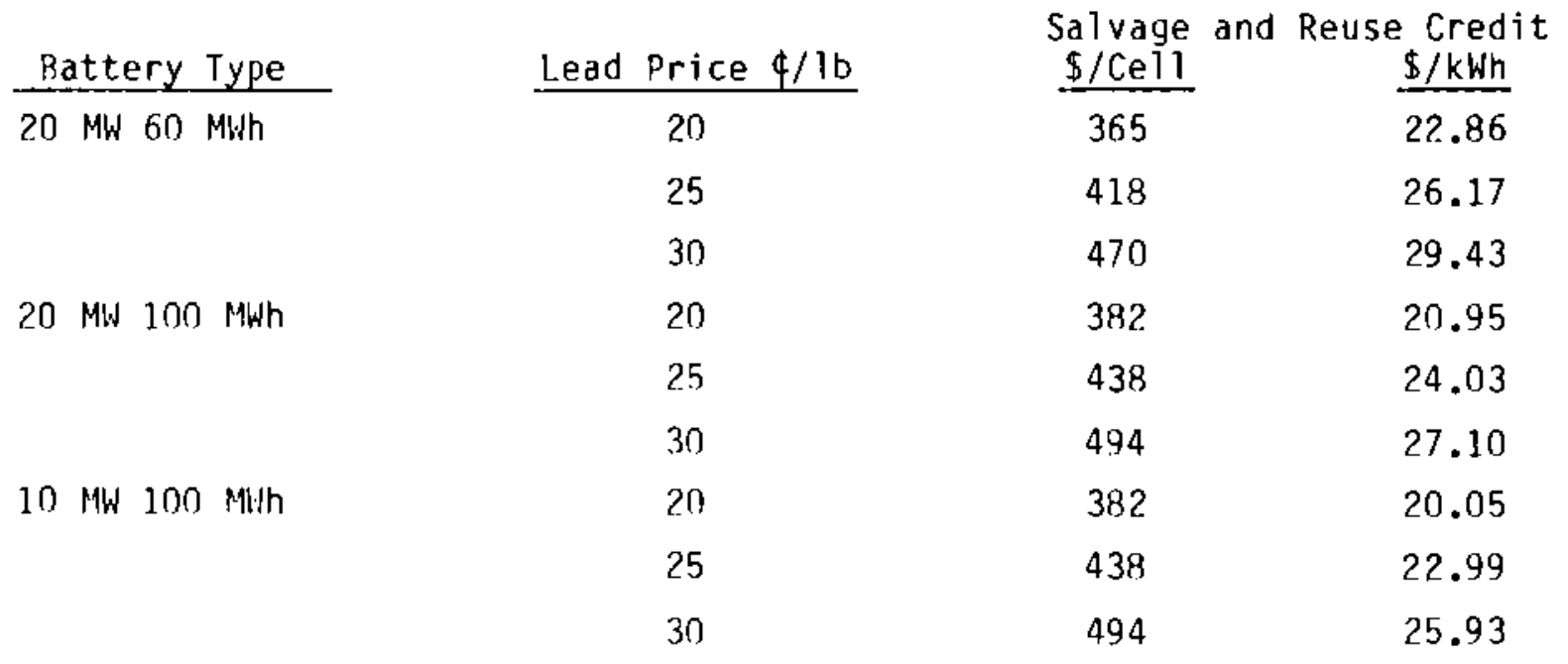


TABLE C.3. Ferrell (1977) Plant and Equipment Cost and Manning Estimates - VLL-45 Cell Produced at 54,840 Per Year Three Shift Operation

\begin{tabular}{|c|c|c|c|c|}
\hline Operation & $\begin{array}{l}\text { Number of } \\
\text { Pieces of } \\
\text { Equipment }\end{array}$ & $\begin{array}{l}\text { Estimated } \\
\text { Total Cost of } \\
\text { Equipment }\end{array}$ & $\begin{array}{l}\text { Manning } \\
\text { Required }\end{array}$ & $\begin{array}{l}\text { Floor } \\
\text { Space } \\
\text { Required } \\
\text { Sq Ft }\end{array}$ \\
\hline 0xide Manufacturing and Handling & 3 & $1,500,000$ & 4 & 15,000 \\
\hline Negative Grid Casting & 2 & 300,000 & 6 & 7,500 \\
\hline \multicolumn{5}{|l|}{ Negative Pasting: } \\
\hline Mixers & 2 & 270,000 & 6 & 2,000 \\
\hline Pasting Machine & 1 & 125,000 & 12 & 2,000 \\
\hline Miscellaneous & 1 & 105,000 & -- & 4,500 \\
\hline Positive Grid Casting & 4 & 500,000 & 9 & 8,000 \\
\hline Positive Tubing Manufacturing & 1 & 200,000 & 5 & 5,000 \\
\hline Positive Filling Machines & 4 & 600,000 & 9 & 12,000 \\
\hline Plate Finishing & 1 & 500,000 & 26 & 20,000 \\
\hline Strap Casting and Finishing & 2 & 200,000 & 28 & 10,000 \\
\hline Assembly & 5 & 550,000 & 105 & 20,000 \\
\hline Finish, pack and ship & 1 & 300,000 & 38 & 15,000 \\
\hline Total - Direct & & $5,150,000$ & 248 & 121,000 \\
\hline Plant Support & & 750,000 & 92 & 39,000 \\
\hline Services and office & & 100,000 & 50 & 10,000 \\
\hline Total & & $6,000,000$ & 390 & 170,000 \\
\hline Inflation and Contingency at $20 \%$ & & $1,200,000$ & -- & 30,000 \\
\hline Total & & $7,200,000$ & 390 & 200,000 \\
\hline Building, all Improvements & & $7,000,000$ & - & -- \\
\hline Land, 10 Acres & & 200,000 & -- & -- \\
\hline Grand Total & & $\$ 14,400,000$ & 390 & 200,000 \\
\hline
\end{tabular}


TABLF C.4. Ferrell (1977) Plate Grid, Terminal and Active Material Price Estimates for VLL45 and VLL43 Cells

\begin{tabular}{|c|c|c|c|c|c|c|c|c|c|}
\hline Item. & \multicolumn{3}{|c|}{$\begin{array}{r}20 \text { MW } 60 \text { MWh } \\
\text { Battery } 3756 \text { Cells } \\
\text { lb/kWh } \\
\begin{array}{c}\text { \$cell } \$ / \mathrm{kWh} \quad \text { (Rated) } \\
\end{array}\end{array}$} & \multicolumn{3}{|c|}{$\begin{array}{c}20 \text { MW } 100 \text { MWh } \\
\text { Battery } 5484 \begin{array}{l}\text { Cells } \\
1 \mathrm{~b} / \mathrm{kWh} \\
\text { (Rated) }\end{array} \\
\begin{array}{c}\text { \$/cell } \$ / \mathrm{kWh} \\
\end{array}\end{array}$} & \multicolumn{3}{|c|}{$\begin{array}{r}10 \text { MW } 100 \text { MWh } \\
\text { Battery } 5250 \begin{array}{r}\text { Cells } \\
1 \mathrm{~b} / \mathrm{kWh} \\
\text { (Rated) }\end{array} \\
\begin{array}{r}\$ / \text { cell } \$ / \mathrm{kWh} \\
\end{array}\end{array}$} \\
\hline \multirow[t]{2}{*}{ Positive Grid: } & 67.20 & 4.21 & 21.0 & 71.60 & 3.93 & 19.6 & 71.60 & 3.76 & 18.8 \\
\hline & 43.00 & 2.69 & 1.4 & 45.60 & 2.50 & 1.3 & 45.60 & 2.39 & 1.2 \\
\hline Positive Active Material & 78.00 & 4.88 & 24.4 & 84.54 & 4.64 & 23.2 & 84.54 & 4.44 & 22.2 \\
\hline Negative Grid & 41.60 & 2.60 & 13.0 & 43.42 & 2.38 & 11.9 & 43.42 & 2.28 & 11.4 \\
\hline Negative Active Material & 62.40 & 3.91 & 19.5 & 67.64 & 3.71 & 18.0 & 67.64 & 3.55 & 17.7 \\
\hline Post Terminal Pb & 11.94 & 0.75 & 3.7 & 12.50 & 0.69 & 3.4 & 12.50 & 0.66 & 3.3 \\
\hline Electrolyte & 5.01 & 0.31 & 31.0 & 5.21 & 0.29 & 28.3 & 4.20 & 0.22 & 26.4 \\
\hline Total Price & 309.15 & 19.36 & 114.0 & 330.57 & 18.14 & 100.3 & 329.50 & 17.30 & 101.0 \\
\hline Cell Type & \multicolumn{3}{|c|}{ VLL43 (HSG) } & \multicolumn{3}{|c|}{ VLL45 (HSG) } & \multicolumn{3}{|c|}{ VLL45（LSG） } \\
\hline Rated kWh $\left(H^{2}\right)$ & \multicolumn{3}{|c|}{$15.97(3 \mathrm{~h})$} & \multicolumn{3}{|c|}{$18.23(5 \mathrm{~h})$} & \multicolumn{3}{|c|}{$19.05(1 \mathrm{~h})$} \\
\hline Depth of Discharge $\%$ & \multicolumn{3}{|c|}{90} & \multicolumn{3}{|c|}{85} & \multicolumn{3}{|c|}{80} \\
\hline
\end{tabular}

Note: 1. Lead at $\$ 0.20$ per $1 b$; Sb at $\$ 2.00$ per $1 b$. 
TABLE C.5. Ferrell (1977) Battery Shipping Costs

\begin{tabular}{|c|c|c|c|c|c|c|c|c|}
\hline \multicolumn{3}{|c|}{ Battery } & \multirow{2}{*}{$\begin{array}{l}\text { Shipping } \\
\text { Weight } \\
\text { MM ib } \\
\end{array}$} & \multirow{2}{*}{$\begin{array}{l}\text { No. } \\
\text { Loads } \\
\text { Each }\end{array}$} & \multirow{2}{*}{\multicolumn{2}{|c|}{$\begin{array}{l}\text { Projected SH } \\
100 \quad 200\end{array}$}} & \multirow[b]{2}{*}{$\begin{array}{l}\text { ipping } \\
300 \\
\end{array}$} & \multirow[b]{2}{*}{$\begin{array}{r}\text { Cost, } \$ / \mathrm{klh} \\
500 \mathrm{miles} \\
\end{array}$} \\
\hline $\begin{array}{l}\text { Power } \\
\text { MW }\end{array}$ & $\begin{array}{l}\text { Energy } \\
\text { MWh }\end{array}$ & $\begin{array}{l}\text { Cells } \\
\text { Each }\end{array}$ & & & & & & \\
\hline 10 & 100 & 5250 & 9.54 & 241 & 1.11 & 1.19 & 1.64 & 1.98 \\
\hline 20 & 60 & 3756 & 7.74 & 194 & 1.48 & 1.59 & 2.19 & 2.52 \\
\hline 20 & 100 & 5484 & 11.97 & 299 & 1.38 & 1.17 & 2.03 & 2.33 \\
\hline
\end{tabular}


TABLE C.6. Ferrell (1977) Battery Transportation and Installation

\begin{tabular}{|c|c|c|c|c|c|c|c|}
\hline \multirow{2}{*}{$\begin{array}{l}\text { Power } \\
\text { Energy Output } \\
\text { Price }\end{array}$} & \multirow[t]{2}{*}{$\begin{array}{l}\text { MW } \\
\text { MWh }\end{array}$} & \multicolumn{2}{|c|}{$\begin{array}{r}10 \\
100 \\
\end{array}$} & \multicolumn{2}{|c|}{$\begin{array}{l}20 \\
60 \\
\end{array}$} & \multicolumn{2}{|c|}{$\begin{array}{r}20 \\
100 \\
\end{array}$} \\
\hline & & $\$$ & $\$ / \mathrm{kWh}$ & $\$$ & $\$ / \mathrm{k} w \mathrm{~h}$ & $\$$ & $\$ / \mathrm{kWh}$ \\
\hline Transportation 500 miles & & 188,000 & 1.88 & 151,200 & 2.52 & 233,000 & 2.33 \\
\hline $\begin{array}{l}\text { Installation, Formation } \\
\text { Charge and First Cycle }\end{array}$ & & 72,670 & 0.73 & 52,430 & 0.87 & 75,835 & 0.76 \\
\hline $\begin{array}{l}\text { Total Transportation and } \\
\text { Installation }\end{array}$ & & 260,670 & 2.61 & 203,630 & 3.39 & 308,835 & 3.09 \\
\hline
\end{tabular}


TABLE C.7. Ferrell (1977) Battery Cooling System Costs

\begin{tabular}{|c|c|c|c|c|}
\hline Cooling System & $\begin{array}{r}20 \mathrm{MW} \\
\mathrm{K \$} \\
\end{array}$ & $\begin{array}{c}\text { MWh Battery } \\
\$ / \mathrm{kWh}\end{array}$ & $\begin{array}{c}20 \mathrm{MW} 100 \\
\mathrm{KS}\end{array}$ & $\begin{array}{r}\text { MWh Bat } \\
\$ / \mathrm{kWh} \\
\end{array}$ \\
\hline \multicolumn{5}{|l|}{ Without Back-Up Components } \\
\hline Ion exchanger & 24 & 0.40 & 24 & 0.24 \\
\hline Cooling Towers & 225 & 3.75 & 275 & 2.75 \\
\hline Pumps, valves, piping & 69 & 1.15 & 103 & 1.03 \\
\hline Assembly labor & 56 & 0.93 & 75 & 0.75 \\
\hline $\mathrm{OH}$, G\&A, Profit & 163 & 2.72 & 217 & $\underline{2.17}$ \\
\hline Price & 537 & 8.95 & 694 & 6.94 \\
\hline \multicolumn{5}{|l|}{ With Back-11p Equipment } \\
\hline Ion exchanger & 24 & 0.40 & 24 & 0.24 \\
\hline Cooling towers & 250 & 4.17 & 300 & 3.00 \\
\hline Pumps, valves, piping & 92 & 1.53 & 141 & 1.41 \\
\hline Assembly labor & 57 & 0.95 & 82 & 0.82 \\
\hline$O H, G \& A$, Profit & $17 ?$ & 2.87 & 241 & 2.41 \\
\hline Price & 595 & 9.92 & 788 & 7.88 \\
\hline
\end{tabular}




\section{TABLE C.8. Ferrell (1977) Air-Lift Stirrer Costs}

20 MW 60 MWh Battery

Component

Rotary vane compressor

Piping, valves, flowmeters, filters

Assembly labor

$\mathrm{OH}$, G\&A, Profit

Price
$\frac{\mathrm{K} \$}{2.0} \quad \frac{\$ / \mathrm{kWh}}{0.10}$

$2.0 \quad 0.10$

$10.0 \quad 0.17$

$\underline{24.6} \quad \underline{0.41}$

$38.6 \quad 0.64$
$20 \mathrm{MW} 100 \mathrm{MWh}$ Battery $\frac{\mathrm{K} \$}{3.0} \quad \frac{\$ / \mathrm{KWh}}{0.03}$

$3.0 \quad 0.03$

$13.7 \quad 0.14$

$\underline{33.9} \quad \underline{0.34}$

$\underline{53.6} \quad 0.54$ 
TABLE C.9. Ferrell (1977) Electrical Monitoring Costs

\begin{tabular}{|c|c|c|c|c|}
\hline Electrical System Cost Element & $\begin{array}{r}20 \mathrm{MW} 60 \\
\mathrm{~K} \$ \\
\end{array}$ & $\begin{array}{l}\text { MWh Battery } \\
\$ / \mathrm{kWh}\end{array}$ & $20 \mathrm{MW} 100$ & $\begin{array}{l}\text { MWh Ba } \\
\$ / \mathrm{kWh}\end{array}$ \\
\hline Hardware, parts, etc. & 31.7 & 0.53 & 40.2 & 0.40 \\
\hline Computer & 16.5 & 0.28 & 16.5 & 0.17 \\
\hline Assembly labor & 13.3 & 0.22 & 13.7 & 0.14 \\
\hline$O H, G \& A$, and Profit & 37.0 & 0.62 & 39.4 & 0.39 \\
\hline Price & 98.5 & $\underline{1.65}$ & 109.8 & $\underline{1.10}$ \\
\hline
\end{tabular}


TABLE C.10. Ramsay (1982) Manufacturing Cost Estimate Low-Maintenance Lead Acid: Capital Cost and Salvage Value

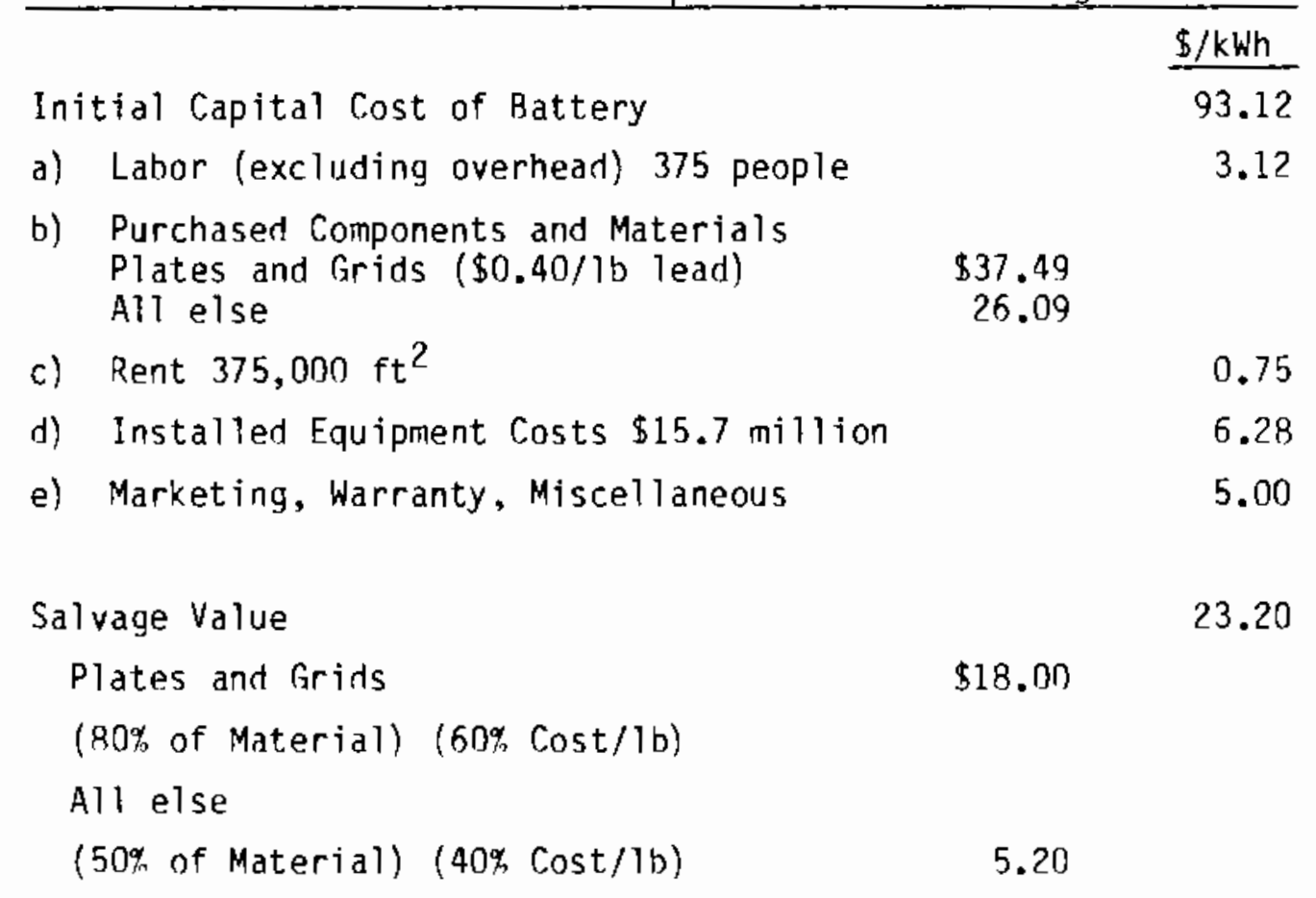

PNL Note: Manufactured cost estimate of $\$ 93.12 / \mathrm{kWh}(1980 \$)$ was inflated to $\$ 116 / \mathrm{kWh}$ (1984\$). 
TABLE C.11. Ramsay (1982) Balance of System Costs

Low-Maintenance Lead Acid: Other Costs of Commercial System

Commercial System (2 MWh and $400 \mathrm{~kW}$ )

$\$ / k W h$

- Ancillary Equipment

- Automatic water system

25.00

- Ventilation and cooling equipment

6.00

- Racks

1.50

- Controls and sensors

5.00

- Electrolyte spill containment

4.00

- Prefabricated enclosure

5.00

- Electrical connections and protectors

2.50

$\$ 49.00$

- Operation and Maintenance Scenario

- 2-1/2\% annual cell failure rate

- Individual cell replacement: 4 man-hours

- Bulk cell replacements: 0.4 man-hours

- Scheduled maintenance: 2 man-days/month

- Unscheduled maintenance: 6 man-days/year

Present worth of O\&M over system lifetime

$6 \%$ discount rate: $\$ 137,700$

$8 \%$ discount rate: $\$ 116,800$ 


\section{TABLE C.12. Ramsay (1982) Life-Cycle Cost Estimates}

Low-Maintenance Lead Acid: Commercial System Summary Costs

Nominal System Rating: 2 MWh and $400 \mathrm{~kW}$

Output Voltage: $110 \mathrm{~V}_{\mathrm{AC}}$

Battery Depth of Discharge: $50 \%$

Initial Battery Capacity: $4 \mathrm{MWh}$

Battery Cutoff Voltage: $1.75 \mathrm{~V}_{\mathrm{DC}} / \mathrm{Cell}$

Converter Efficiency: $95 \%$

System Configuration: 8 parallel rows of 66 cells in series. Total: $528 \mathrm{Cells}$

Cell Capacity: $7.58 \mathrm{kWh}$

\begin{tabular}{|c|c|c|}
\hline & Discour & Rate \\
\hline & $6 \%$ & $8 \%$ \\
\hline Initial Capital Cost of Battery & 372,500 & $\$ 372,500$ \\
\hline $\begin{array}{l}\text { Initial Capital Cost of } \\
\text { Ancillary Equipment }\end{array}$ & 196,000 & 196,000 \\
\hline $\begin{array}{l}\text { Present Worth of Battery } \\
\text { Replacement Costs }\end{array}$ & 352,800 & 293,400 \\
\hline $\begin{array}{l}\text { Present Worth of Annual Operation } \\
\text { and Maintenance Costs }\end{array}$ & 137,700 & 116,800 \\
\hline $\begin{array}{l}\text { Present Worth of Battery at } \\
\text { End of System Life }\end{array}$ & $(44,900)$ & $(30,900)$ \\
\hline $\begin{array}{l}\text { Present Worth of Ancillary } \\
\text { Equipment at End of System Life }\end{array}$ & $(12,200)$ & $(8,400)$ \\
\hline Life Cycle Cost & $\$ 1,002,000$ & $\$ 939,500$ \\
\hline $\begin{array}{l}\text { Life Cycle Cost/kWh of Battery } \\
\text { Capacity }\end{array}$ & $\$ 501 / \mathrm{kwh}$ & $\$ 470 / k^{w h}$ \\
\hline
\end{tabular}

PNL Note: Life-cycle costs of $\$ 470-501 / \mathrm{kWh}(1980 \$)$ were inflated to $\$ 586-625 / \mathrm{kWh}(1984 \$)$. 
TABLE C.13. Ramsay (1982) Manufacturing Cost Estinate Low-Maintenance Lead Acid: Capital Cost and Salvage Value

Initial Capital Cost of Battery

$\$ / k W h$

a) Labor (excluding overhead) 375 people 100.72

b) Purchased Components and Materials Plates and Grids ( $\$ 0.40 / 1 \mathrm{~b}$ lead)

All else

$\$ 35.60$

34.32

c) Rent $375,000 \mathrm{ft}^{2}$

3.12

d) Installed Equipment Costs $\$ 15.7$ million

69.92

e) Marketing, Warranty, Miscellaneous

0.75

6.28

5.00

Salvage Value

23.95

- Plates and Grids

$\$ 17.10$

(80\% of Material) (60\% Cost/1b)

All else

(50\% of Material) (40\% Cost/1b)

6.85

PNL Note: Manufactured cost of $\$ 100.72 / \mathrm{kWh}(1980 \$)$ was inflated to $\$ 126 / \mathrm{kWh}(1984 \$)$. 
TABLE C.14. Ramsay (1982) Balance of System Costs

Maintenance-Free Lead Acid MFX: Other Costs of Commercial System

Commercial System (2 MWh and $400 \mathrm{~kW}$ )

$\$ / k W h$

- Ancillary Equipment

- Cooling equipment

6.00

- Racks

1.50

- Controls and sensors

5.00

- Prefabricated enclosure

5.00

- Electrical connections and protectors

2.50

$\$ 20.00$

- Operation and Maintenance Scenario

- 2-1/2\% annual cell failure rate

- Individual cell replacement: 4 man-hours

- Bulk cell replacements: 0.4 man-hours

- Scheduled maintenance: 1 man-day/month

- Unscheduled maintenance: 2 man-days/year

Present worth of O\&M over system lifetime

$6 \%$ discount rate: $\$ \$ 4,650$

$8 \%$ discount rate: $\$ 71,400$ 
TABLE C.15. Ramsay (1982) Life-Cycle Cost Estimates

Maintenance-Free Lead Acid: Commercial System Summary Costs

Nominal System Rating: 2 MWh and $400 \mathrm{~kW}$

Dutput Voltage: $110 V_{A C}$

Battery Depth of Discharge: $80 \%$

Initial Battery Capacity: $2.5 \mathrm{MWh}$

Battery Cutoff Voltage: $1.75 \mathrm{~V}_{D C} /$ Cell

Converter Efficiency: $95 \%$

System Configuration: 8 parallel rows of 66 cells in series. Total: 528 Cells

Cell Capacity: $4.74 \mathrm{kWh}$

Initial Capital Cost of Battery

Initial Capital Cost of

Ancillary Equipment

Present worth of Battery

Replacement Costs

Present Worth of Annual Operation and Maintenance Costs

Present Worth of Battery at

End of System Life

Present Worth of Ancillary

Equipment at End of System Life

Life Cycle Cost

Life Cycle Cost/kWh of Battery

Capacity

$\begin{array}{rr}\frac{\text { Discount Rate }}{6 \%} & \frac{8 \%}{\$ 251,800} \quad \frac{\$ 251,800}{50,000} \\ 50,000\end{array}$

242,100

201,400

84,650

71,400

$(29,600)$

$(20,400)$

$(3,750)$

$(2,600)$

$\$ 595,200$

$\$ 551,600$

$\$ 298 / \mathrm{kWh}$

$\$ 276 / \mathrm{kWh}$

PNL Note: Life-Cycle costs of $\$ 276-298 / \mathrm{kWh}$ (1980 \$) were inflated to $\$ 344-371 / \mathrm{kWh}(1984 \$)$. 
TABLE C.16. Long (1977) Manufacturing Cost Estimates

Summary of Results

State-0f-The-Art

1) $25 \$ / 1 \mathrm{~b}$, lead

2) Manufacturing plant vertical integration and $25 \% / 1 \mathrm{~b}$ lead

3) Effective lead cost $19 \$ / 1 \mathrm{~b}$ with manufacturing plant vertical integration

4) Recycled batteries 104/1b lead
Projected Selling

Direct Product Costs $(\$ / \mathrm{kWh})$

$\$ 36.81$

34.30

29.73

22.96
Price $(\$ / \mathrm{kWh})$

With Moderate Risk

$\$ 48.25$

45.48

40.50

32.65

29.87 
TABLE C.17. Long (1977) kw 160-45 Material Cost Est imate

\section{Assumptions}

1. At $\$ 0.25 / 1 b$ lead

a. $4 \%$ antimonial grid lead costs $\$ 0.315 / 1 \mathrm{~b}$

h. Negative oxide cost (1 itharge) $\$ 0.276 / 1 \mathrm{~b}$

c. Positive oxide (red lear) $\$ 0.286 / 1 b$

2. Plate yield $=97.5 \%$ ( $80 \%$ of loss recoverable)

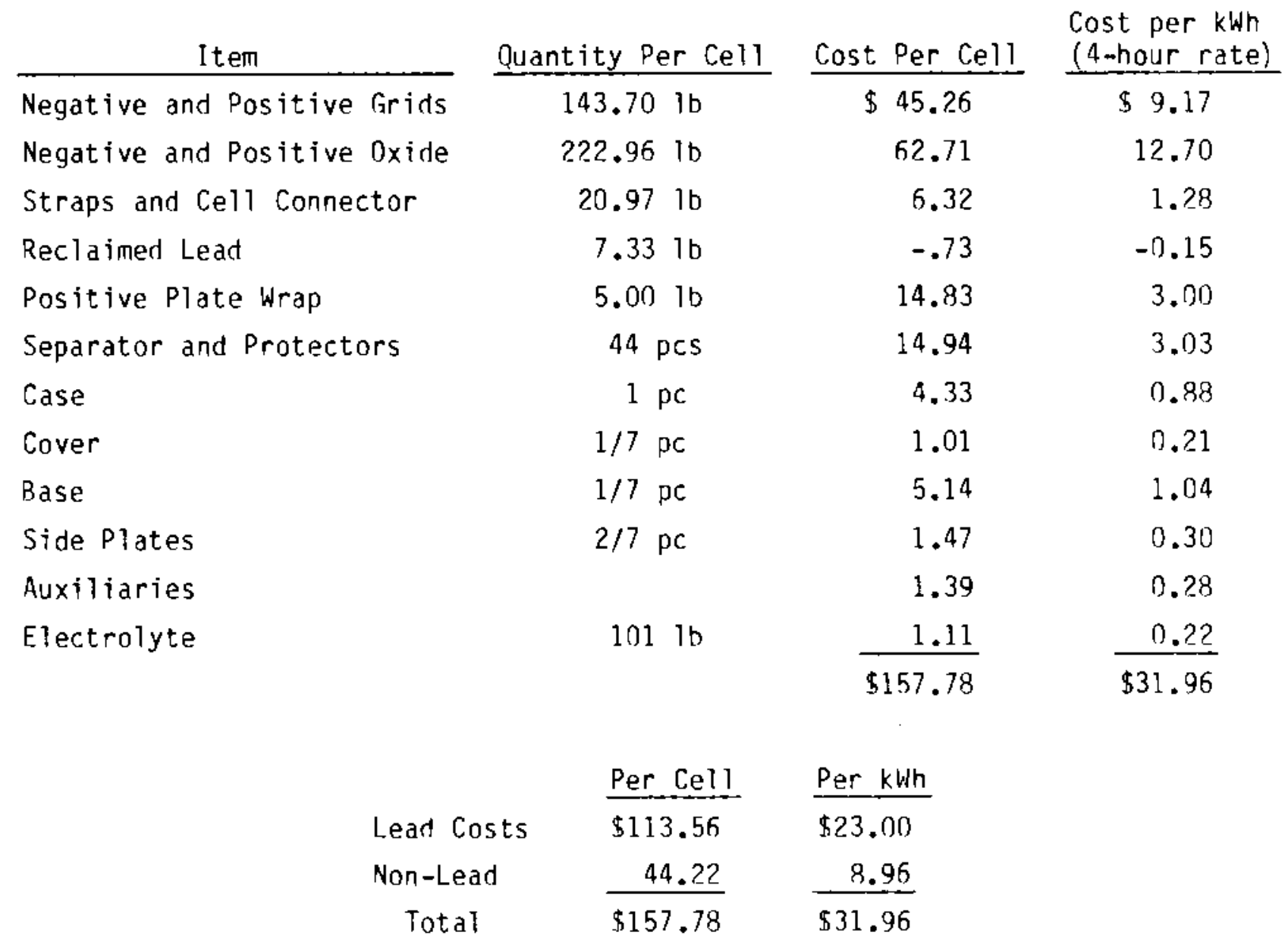


TABLE C.18. Long (1977) Plant, Equipment and Labor Estimates KW 160-45 40 MWh Battery 25 Batteries/Year Three Shift Operation

\begin{tabular}{|c|c|c|c|c|}
\hline Operation & $\begin{array}{l}\text { Number of } \\
\text { Pieces of } \\
\text { Equipment }\end{array}$ & $\begin{array}{l}\text { Estimated } \\
\text { Total Cost of } \\
\text { Equipment } \\
\end{array}$ & $\begin{array}{l}\text { Operation } \\
\text { Required } \\
\end{array}$ & $\begin{array}{r}\text { Floor } \\
\text { Space } \\
\text { Required } \\
\text { Sq Ft } \\
\end{array}$ \\
\hline Oxide Handling and Mixing. & 18 & $\$ 224,000$ & 6.0 & 11,000 \\
\hline Alloying Furnaces & 3 & 90,000 & 6.0 & 750 \\
\hline Grid and Parts Casting & 11 & 471,000 & 27.0 & 12,500 \\
\hline Plate Pasting & 3 & 136,000 & 27.0 & 2,250 \\
\hline Plate Drying and Curing & 11 & 600,000 & 7.5 & 6,300 \\
\hline Pos. Plate Wrapping & 17 & 200,000 & 24.0 & 3,400 \\
\hline Assembly Plates and Cast Straps & 1 & 200,000 & 15.0 & 1,250 \\
\hline Place Cells in Jar, Place on Base & 3 & 145,000 & 6.0 & 3,250 \\
\hline Jar, Cover and Base Molds & 3 & 112,000 & & \\
\hline Burn Intercell Connection & Misc & 20,000 & 4.5 & 3,100 \\
\hline Continued Test and Repair & Misc & 45,000 & 3.0 & 2,250 \\
\hline Prepare Cover & Misc & 50,000 & 4.5 & 1,000 \\
\hline Attach Cover and Complete Module & Misc & 20,000 & 1.5 & 2,250 \\
\hline Shipping and Receiving & Misc & 120,000 & 12.0 & 20,000 \\
\hline Machine Shop and Laboratories & Misc & 195,000 & $0 . H$. & 1,750 \\
\hline $\begin{array}{l}\text { Spare Parts Inventory } \\
\text { Waste and Stack }\end{array}$ & Misc & 160,000 & $0 . \mathrm{H}$ & 500 \\
\hline Gas Treatment & & In Bidg Cost & $0 . H$. & 4,000 \\
\hline Medical Health & Misc & 20,000 & & 200 \\
\hline Aisle and Laydown Space & & & & 40,250 \\
\hline Plant Service & & & & 4,000 \\
\hline Office & & 71,000 & & 10,000 \\
\hline \multirow[t]{2}{*}{ Total } & & $\$ 2,879,000$ & 144.0 & 130,000 \\
\hline & & & \multicolumn{2}{|c|}{$\frac{+6.0}{150.0}$ Relief } \\
\hline
\end{tabular}


TABLE C.19. Long (1977) Administrative and General Functions

Plant Manager
Secretary.
Controller
Payroll Clerk
A/P, A/R and General Accounting Clerks
Cost Accountant
Materials Manager
Buyers
Purchasing Clerk
Personnel Relations Manager
Benefits Clerk
Medical
Total A\&G Salaries
Renefits
Computer Costs
Telephone Costs
Travel Costs
Supplies, Copies and Miscellaneous
Total A\&g Management Cost

\begin{tabular}{ccc} 
Salary Rate & Quantity & Total Cost \\
\cline { 1 - 1 } $45 \mathrm{~K}$ & 1 & $\$ 45 \mathrm{~K}$ \\
$12 \mathrm{~K}$ & 1 & $12 \mathrm{~K}$ \\
$30 \mathrm{~K}$ & 1 & $30 \mathrm{~K}$ \\
$10 \mathrm{~K}$ & 1 & $10 \mathrm{~K}$ \\
$10 \mathrm{~K}$ & 2 & $20 \mathrm{~K}$ \\
$12 \mathrm{~K}$ & 1 & $12 \mathrm{~K}$ \\
$25 \mathrm{~K}$ & 1 & $25 \mathrm{~K}$ \\
$15 \mathrm{~K}$ & 1 & $15 \mathrm{~K}$ \\
$10 \mathrm{~K}$ & 1 & $10 \mathrm{~K}$ \\
$30 \mathrm{~K}$ & 1 & $30 \mathrm{~K}$ \\
$10 \mathrm{~K}$ & 1 & $10 \mathrm{~K}$ \\
$15 \mathrm{~K}$ & 1 & $15 \mathrm{~K}$ \\
& 13 & $\$ 234 \mathrm{~K}$ \\
& & $47 \mathrm{~K}$ \\
& & $50 \mathrm{~K}$ \\
& & $10 \mathrm{~K}$ \\
& & $10 \mathrm{~K}$ \\
& & $\frac{24 \mathrm{~K}}{\underline{3375 K}}$
\end{tabular}


TABLE C.20. Long (1977) Engineering and Service Functions

\begin{tabular}{|c|c|c|c|}
\hline & Salary Rate & Quantity & Total Cost \\
\hline Engineering and Service Manager & $30 \mathrm{~K}$ & 1 & $\$ 30 \mathrm{~K}$ \\
\hline Customer Service Engineer & $18 k$ & 2 & $36 k$ \\
\hline Drafters & $13 K$ & 1 & $13 K$ \\
\hline Installation Engineers & $18 K$ & 2 & $36 \mathrm{~K}$ \\
\hline Order Correspondent & $15 x$ & 1 & $15 k$ \\
\hline Secretary & $8 K$ & 1 & $8 \mathrm{~K}$ \\
\hline Total Engineering and Service Salaries & & 8 & $\$ 138 K$ \\
\hline Benefits & & & $27 k$ \\
\hline Telephone Costs & & & $15 K$ \\
\hline Travel Costs & & & $55 \mathrm{~K}$ \\
\hline Supplies Copies and Miscellaneous & & & $25 k$ \\
\hline Total Engineering and Service Costs & & & $\$ 260 K$ \\
\hline
\end{tabular}


TABLE C.21. Long (1977) Manufacturing Functions

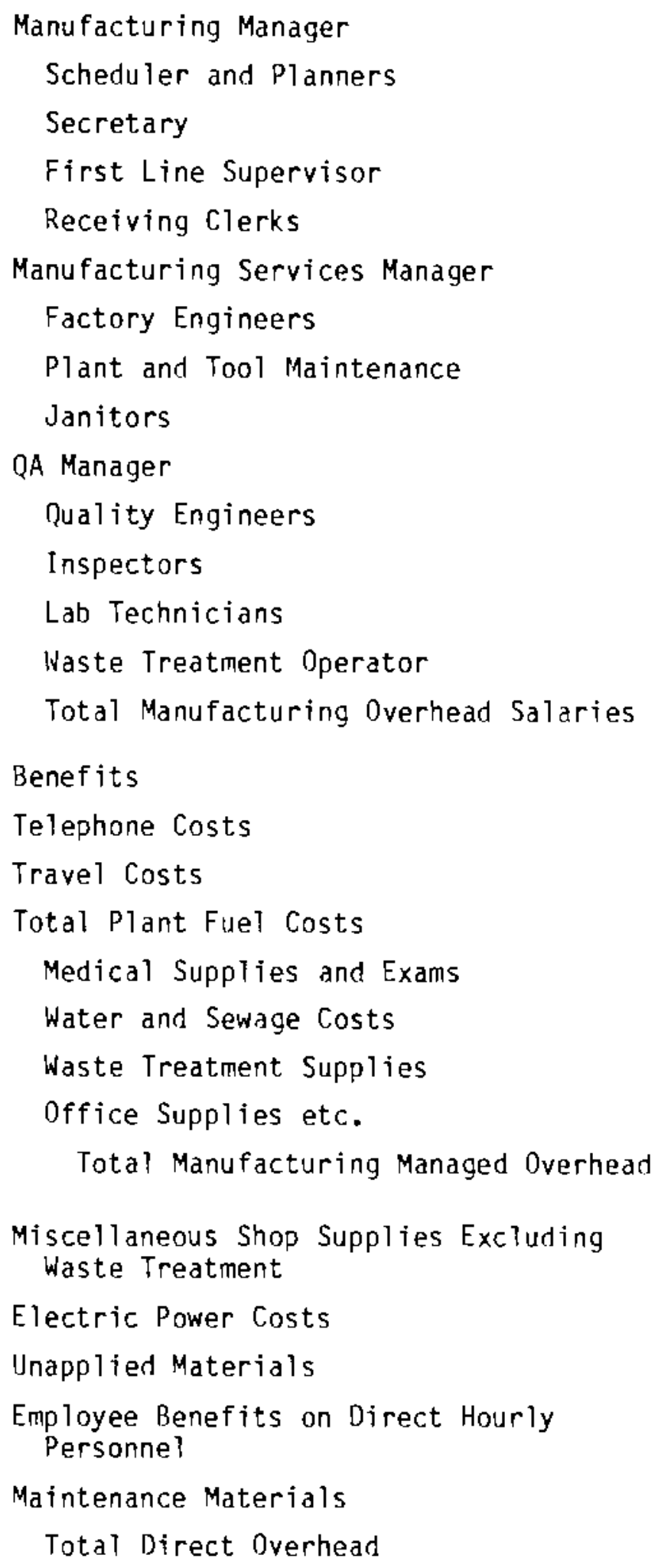

Telephone Costs

Travel Costs

Total Plant Fuel Costs

Medical Suppiies and Exams

Water and Sewage costs

Waste Treatment Supplies

Office Supplies etc.

Total Manufacturing Managed Overhead

Miscellaneous Shop Supplies Excluding waste Treatment

Electric Power Costs

Unapplied Materials

Employee Benefits on Direct Hourly Personne?

Maintenance Materials

Total Direct Overhead

$8 \mathrm{~K}$

1.

2

1

6

2

1

2

12

2

1

1

3

2

$\frac{1}{37}$

$24 \mathrm{~K}$

$10 \mathrm{~K}$

$102 \mathrm{~K}$

$20 \mathrm{~K}$

$25 \mathrm{~K}$

$36 \mathrm{~K}$

$180 \mathrm{~K}$

$16 \mathrm{~K}$

$25 \mathrm{~K}$

$18 \mathrm{~K}$

$36 \mathrm{~K}$

30K

$17 \quad \frac{8 K}{\$ 565 K}$

$113 K$

$5 \mathrm{~K}$

10K

$285 \mathrm{~K}$

$25 \mathrm{~K}$

$80 \mathrm{~K}$

$40 \mathrm{~K}$

$20 \mathrm{~K}$

$\$ 1143 \mathrm{~K}$

$50 \mathrm{~K}$

$300 \mathrm{~K}$

200K

$326 \mathrm{~K}$

$150 \mathrm{~K}$

$\$ 1026 \mathrm{~K}$ 
TABLE C.22. Long (1977) Other costs

Transportation Costs - Truck (\$1.60/kWh) $\$ 1,600 \mathrm{~K}$

Product Warranty Costs $(\$ 0.35 / \mathrm{kWh}) \quad 350 \mathrm{~K}$

Selling Costs 700K

Insurance and Taxes

$\begin{array}{r}175 K \\ \$ 2,825 K \\ \hline\end{array}$

Total Other Costs 
TABLE C.23. Long (1977) Summary of Cost Data (Lead at 25 $\$ / 1 b$ )

Land (50 acres)

$\$ 250 \mathrm{~K}$

Building $(130,000 \mathrm{sq} f t)$

$3,800 \mathrm{~K}$

Machinery and Equipment

Total Capital Investment

$2,200 \mathrm{~K}$

Factory Tooling

$\$ 6,250 \mathrm{~K}$

Initial Stock of Factory Supplies and Expense Items for Start-up

$\$ 679 K$

Manufacturing Planning (135 man-months)

$51 k$

$270 \mathrm{~K}$

Training and Start-up Costs

$2000 \mathrm{~K}$

Total Strategic Expense

$\$ 3,000 \mathrm{~K}$

Accounts Receivable (45 days)

Inventories

Less: Accounts Payable and Warranty Reserve

Total Working Capital

$\$ 5,210 \mathrm{~K}$

$4,537 \mathrm{~K}$

Direct Labor

$-3,056 k$

0irect Material

$\$ 6,791 \mathrm{~K}$

Transportation

$\$ 1,650 \mathrm{~K} /$ year

Direct Overhead

$31,960 \mathrm{k} /$ year

$1,600 \mathrm{~K} /$ year

Warranty

Installation Labor

$1,026 \mathrm{~K} /$ year

$350 \mathrm{~K} /$ year

Subtotal Direct Cost

$255 \mathrm{~K} /$ year

Less: Potential Improvement From Vertical Integration

$\$ 36,811 \mathrm{~K} /$ year

Total Direct Cost

$-2,510 \mathrm{~K} /$ year

Administrative and General

Engineering and Service

Manufacturing Managed Overhear

$\$ 34,301 \mathrm{~K} /$ year

$\$ 375 \mathrm{~K} /$ year

260k/year

Marketing

$1,143 \mathrm{~K} /$ year

Insurance and Taxes

$700 \mathrm{~K} /$ year

Total Indirect Overhead

$175 \mathrm{~K} /$ year

$\$ 2,653 \mathrm{~K} / \mathrm{year}$ 
TABLE C.24. Pittman (1977) Manufacturing Cost Estimates

Sumnary of Results

Advance Technology

1) $25 \% / 1 \mathrm{D}, 1 \mathrm{ead}$

2) Manufacturing plant vertical integration and $254 / 1 \mathrm{~b}$ lead

3) Effective lead cost $194 / 1 \mathrm{~b}$ with manufacturing plant vertical integration

4) Replacement batteries $10 \$ / 1 \mathrm{~b}$ lead
Direct Product
Costs $(\$ / \mathrm{kWh})$

$\$ 32.36$

34.30

25.44

20.17
Projected Selling

Price ( $\$ / \mathrm{k} W \mathrm{~h})$

With Moderate Risk

$\$ 41.77$

38.80

34.50

28.75
Projected Selling Price (\$kWh)

With Low Risk $\$ 38.53$

35.50

31.62

25.85

PNL Note: The manufacturing cost estimate of $\$ 41.77 / \mathrm{kWh}(1976 \$)$ was inflated to $\$ 70 / \mathrm{kWh}(1984 \$)$. 
TABLE C.25. Pittman (1977) WE 67 Material Cost Estimate

1. At $\$ 0.25 / 1 b$ lead

\section{Assumptions}

a. Grid lead costs

b. Negative oxide cost (1itharge) $\$ 0.275 / 1 \mathrm{~b}$

c. Positive oxide (red lead) $\$ 0.286 / 1 \mathrm{~b}$

2. Plate yield $=97.5 \%$ ( $80 \%$ of loss recoverable)

\begin{tabular}{|c|c|c|c|c|c|}
\hline \multicolumn{2}{|l|}{ Item } & \multicolumn{2}{|c|}{ Qty. Per Cell } & \multirow{2}{*}{$\frac{\text { Cost Per Cell }}{\$ 420.29}$} & \multirow{2}{*}{$\begin{array}{l}\begin{array}{l}\text { Cost per kwh } \\
\text { (4-hour rate) }\end{array} \\
\$ 8.57\end{array}$} \\
\hline Negative and Positive & Ie Grids & 1194 & lb & & \\
\hline Negative and Positive & exide & 1671 & $1 b$ & 470.28 & 9.59 \\
\hline Straps and Posts & & 227 & $1 \mathrm{~b}$ & 70.99 & 1.45 \\
\hline Reclaimed Lead & & & $1 b$ & -6.00 & -0.12 \\
\hline Glass Mats & & 1068 & $\mathrm{ft}^{2}$ & 39.52 & 0.81 \\
\hline Positive Plate Wrap & & $1000 \mathrm{f}$ & $\mathrm{ft}^{2}$ & 59.39 & 1.21 \\
\hline Separators & & 528 & $\mathrm{ft}^{2}$ & 129.36 & 2.64 \\
\hline Case & & 1 & $\rho c$ & 36.52 & 0.75 \\
\hline Cover & & $1 f$ & $p c$ & 7.20 & 0.15 \\
\hline Base & & $1 \mathrm{p}$ & $p c$ & 28.20 & 0.58 \\
\hline Side Plates & & $2 f$ & $p c$ & 53.28 & 1.09 \\
\hline Tensioning Device & & $6 p$ & $\mathrm{pc}$ & 30.00 & 0.61 \\
\hline Auxiliaries & & & & 30.36 & 0.62 \\
\hline \multirow[t]{6}{*}{ Electrolyte } & & 1350 & $1 b$ & 14.84 & 0.30 \\
\hline & & $\$ 1384$ & .23 & $\$ 28.25$ & \\
\hline & & & Per Cell & Per kWh & \\
\hline & Lead Costs & & $\$ 939.06$ & $\$ 19.16$ & \\
\hline & Non-Lead & Costs & 445.17 & 9.199 & \\
\hline & Total & & $\$ 1384.23$ & $\$ 28.25$ & \\
\hline
\end{tabular}


TABLE C.26. Pittman (1977) Plant, Fquipment and Labor Estimates WE-67 40 MWh Battery 25 Batteries/Year Three-Shift Operation

\begin{tabular}{|c|c|c|c|c|}
\hline Operation & $\begin{array}{l}\text { Number of } \\
\text { Pieces of } \\
\text { Equipment }\end{array}$ & $\begin{array}{c}\text { Estimated } \\
\text { Total Cost of } \\
\text { Equipment } \\
\end{array}$ & $\begin{array}{l}\text { Oper. } \\
\text { Required }\end{array}$ & $\begin{array}{l}\text { Floor } \\
\text { Space } \\
\text { Required } \\
\text { Sq Ft } \\
\end{array}$ \\
\hline Oxide Mixing and Handling & 16 & $\$ 196,000$ & 18 & 9,000 \\
\hline Plate Processing & 3 & 340,000 & 7 & 2,300 \\
\hline Small Parts Casting & 1 & 71,000 & 1 & 500 \\
\hline Plate Wrapping & 3 & 111,000 & 9 & 550 \\
\hline Terminal Welding & 1 & 170,000 & 9 & 500 \\
\hline Automatic Stacking & 1 & 140,000 & 6 & 2,000 \\
\hline Cast on Posts and Straps & 1 & 250,000 & 12 & 1,500 \\
\hline Mold Jar & 1 & 91,000 & 6 & 2,000 \\
\hline Assemble Cell in Jar & 1 & 185,000 & 6 & 700 \\
\hline Base Cover and Side Plate Molds & 3 & 109,000 & -- & -- \\
\hline $\begin{array}{l}\text { Attach Side Plates and Base to Cell } \\
\text { and Place on Conveyer }\end{array}$ & 1 & 100,000 & 3 & 3,000 \\
\hline Continuity Test and Repair & 1 & 75,000 & 4 & 2,000 \\
\hline Prepare Cover and Attach to Cell & 2 & 130,000 & 12 & 3,500 \\
\hline Shipping and Receiving & Misc & 220,000 & 12 & 20,000 \\
\hline Machine Shop and Laboratories & Misc & 195,000 & $0 . \mathrm{H}$ & 1,750 \\
\hline Spare Parts Inventory & Misc & 120,000 & -- & 500 \\
\hline Medical Health & Misc & 20,000 & 0.4 & 200 \\
\hline Aisle and Laydown Space & & & & 26,000 \\
\hline Plant Service & Misc & 5,000 & $0 . H$. & 4,000 \\
\hline \multirow[t]{3}{*}{ Office } & Misc & $\begin{array}{r}71,000 \\
\end{array}$ & $\underline{0 . H .}$ & 10,000 \\
\hline & & $\$ 2,599,000$ & 105 & 90,000 \\
\hline & & & \multicolumn{2}{|c|}{$\frac{+4}{1}$ Relief } \\
\hline
\end{tabular}


IABLE C.27. Pittman (1977) Administrative and General Functions

Plant Manager
Secretary
Controller
Payroll Clerk
A/P, A/R and General Accounting Clerks
Cost Accountant
Materials Manager
Buyers
Purchasing Clerk
Personnel Relations Manager
Benefits Clerk
Medical
Total A\&G Salaries
Benefits
Computer Costs
Telephone Costs
Travel Costs
Supplies, Copies and Miscellaneous
Total A\&G Mgd. Cost

$\frac{\text { Salary Rate }}{45 \mathrm{~K}} \frac{\text { Quantity }}{1} \frac{\text { Total Cost }}{\$ 45 \mathrm{~K}}$. $12 \mathrm{~K} \quad 1 \mathrm{~K}$

30K $\quad 1 \quad 30 K$

10K $10 \mathrm{~K}$

10K $20 K$

$12 \mathrm{~K} \quad 12 \mathrm{~K}$

$25 K \quad 25 K$

$15 K \quad 15 K$

$10 K \quad 10 K$

$30 \mathrm{~K} \quad \mathrm{I} \quad 30 \mathrm{~K}$

10K $10 \mathrm{~K}$

$15 \mathrm{~K}$

$\frac{1}{13} \quad \frac{15 K}{\$ 234 K}$

$47 \mathrm{~K}$

$50 \mathrm{~K}$

10K

$10 \mathrm{~K}$

$24 \mathrm{~K}$

$\$ 375 \mathrm{~K}$ 
TABLE C.28. Pittman (1977) Engineering and Service Functions

\begin{tabular}{|c|c|c|c|}
\hline & Salary Rate & Quantity & Total Cost \\
\hline Engineering and Service Manager & $30 \mathrm{~K}$ & 1 & $\$ 30 K$ \\
\hline Customer Service Engineer & $18 \mathrm{~K}$ & 2 & $36 K$ \\
\hline Drafters & $13 k$ & 1 & $13 k$ \\
\hline Installation Engineers & $18 \mathrm{~K}$ & 2 & $36 K$ \\
\hline Order Correspondent & $15 k$ & 1 & $15 K$ \\
\hline Secretary & $8 \mathrm{~K}$ & $\underline{1}$ & $\underline{8 K}$ \\
\hline Total Engineering and Service Salaries & & 8 & $\$ 138 K$ \\
\hline Benefits & & & $27 k$ \\
\hline TeTephone Costs & & & $15 K$ \\
\hline Travel Costs & & & $55 \mathrm{~K}$ \\
\hline Supplies Copies and Miscellaneous & & & $25 K$ \\
\hline Total Engineering and Service Costs & & & $\$ 260 \mathrm{~K}$ \\
\hline
\end{tabular}


TABLE C.29. Pittman (1977) Manufacturing Functions

\begin{tabular}{|c|c|c|c|}
\hline & Salary Rate & Quantity & Total Cost \\
\hline Manufacturing Manager & $35 k$ & 1 & $\$ 35 K$ \\
\hline Scheduler and Planners & $12 \mathrm{~K}$ & 2 & $24 k$ \\
\hline Secretary & $10 \mathrm{~K}$ & 1 & $10 \mathrm{~K}$ \\
\hline First Line Supervisor & $17 \mathrm{~K}$ & 6 & $102 \mathrm{~K}$ \\
\hline Receiving Clerks & $10 \mathrm{~K}$ & 2 & $20 \mathrm{x}$ \\
\hline Manufacturing Services Manager & $25 \mathrm{~K}$ & 1 & $25 \mathrm{~K}$ \\
\hline Factory Engineers & $18 \mathrm{k}$ & 2 & $36 \mathrm{~K}$ \\
\hline Plant and Tool Maintenance & $15 K$ & 12 & $180 \mathrm{~K}$ \\
\hline Janitors & $8 \mathrm{~K}$ & 2 & $16 \mathrm{~K}$ \\
\hline QA Manager & $25 \mathrm{~K}$ & 1 & $25 \mathrm{~K}$ \\
\hline Quality Engineers & $18 \mathrm{~K}$ & 1 & $18 \mathrm{~K}$ \\
\hline Inspectors & $12 \mathrm{~K}$ & 3 & $36 \mathrm{~K}$ \\
\hline Lab Technicians & $15 K$ & 2 & $30 \mathrm{~K}$ \\
\hline Waste Treatment Operator & $8 \mathrm{~K}$ & 1 & $8 \mathrm{~K}$ \\
\hline Total Manufacturing Overhead Salaries & & 37 & $\$ 565 K$ \\
\hline Benefits & & & $113 \mathrm{~K}$ \\
\hline Telephone Costs & & & $5 K$ \\
\hline Travel Costs & & & $10 \mathrm{~K}$ \\
\hline Total Plant Fuel Costs & & & $50 \mathrm{~K}$ \\
\hline Medical Supplies and Exams & & & $25 \mathrm{~K}$ \\
\hline Water and Sewage Costs & & & $80 \mathrm{~K}$ \\
\hline Waste Treatment Supplies & & & $40 \mathrm{~K}$ \\
\hline Office Supplies etc. & & & $20 \mathrm{~K}$ \\
\hline Total Manufacturing Managed Overhead & & & $\$ 908 \mathrm{~K}$ \\
\hline $\begin{array}{l}\text { Miscellaneous Shop Supplies Excluding } \\
\text { Waste Treatment }\end{array}$ & & & $50 \mathrm{~K}$ \\
\hline Electric Power Costs & & & $250 \mathrm{~K}$ \\
\hline Inapplied Materials & & & $200 \mathrm{~K}$ \\
\hline $\begin{array}{l}\text { Employee Benefits on Direct Hourly } \\
\text { Personnel }\end{array}$ & & & $238 \mathrm{~K}$ \\
\hline Maintenance Materials & & & $200 \mathrm{~K}$ \\
\hline Total Direct Overhead & & & $\$ 938 \mathrm{~K}$ \\
\hline
\end{tabular}




\begin{tabular}{lr}
\multicolumn{2}{c}{ TABLE C. 30.} \\
\hline Transportation Costs - Truck $(\$ 1.40 / \mathrm{kWh})$ & $\$ 1,400 \mathrm{~K}$ \\
Product Warranty Costs $(\$ 0.35 / \mathrm{kWh})$ & $350 \mathrm{~K}$ \\
Selling Costs & $700 \mathrm{~K}$ \\
Insurance and Taxes & $150 \mathrm{~K}$ \\
Total Other Costs & $\$ 2,600 \mathrm{~K}$ \\
\hline
\end{tabular}


TABLE C..31. Pittman (1977) Summary of Cost Data (Lead at 25 $\$ /$ lb)

Land (50 acres)

Building $(90,000 \mathrm{sq} f \mathrm{t})$

Machinery and Equipment

Total Capital Investment

Factory Tooling

Initial Stock of Factory Supplies and Expense Items for Start-up

Manufacturing Planning (135 man-months)

Training and Start-up Costs

Total Strategic Expense

Accounts Receivable (45 days)

Inventories

Less: Accounts Payable and Warranty Reserve

Total Working Capital

Direct Labor

Direct Material

Transportation

Direct Overhead

Warranty

Installation Labor

Subtotal Direct Cost

Less: Potential Improvement From Vertical Integration

Total Direct Cost

Administrative and General

Engineering and Service

Manufacturing Operations

Marketing

Insurance and Taxes

Total Indirect Overhead
$\$ 250 K$

$2,700 \mathrm{~K}$

$\frac{\frac{2,040 \mathrm{~K}}{\$ 4,990 \mathrm{~K}}}{\$ 559 \mathrm{~K}}$

$46 \mathrm{~K}$ $270 \mathrm{~K}$

$1,855 \mathrm{~K}$

$\frac{\$ 2,730 \mathrm{~K}}{\$ 4,410 \mathrm{~K}}$

$4,010 \mathrm{~K}$

$-2,710 \mathrm{~K}$

$\$ 5,710 \mathrm{~K}$

$\$ 1,200 \mathrm{~K} /$ year

28,250K/year

$1,400 \mathrm{~K} /$ year

938K/year

$350 \mathrm{~K} /$ year

$225 \mathrm{~K} /$ year

$\$ 32,363 \mathrm{~K} /$ year

$-2,940 \mathrm{~K} /$ year

$\$ 29,423 \mathrm{~K} /$ year

$\$ 375 \mathrm{~K} /$ year

$260 \mathrm{~K} /$ year

$908 \mathrm{~K} /$ year

$700 \mathrm{~K} /$ year

150K/year

$\$ 2,393 \mathrm{~K} /$ year 
TABLE C..32. Boden (1977) Manufacturing Cost Estimates

\section{Typical User Costs - C\&n Rattery Design for IItility Peaking Energy Storage}

\begin{tabular}{|c|c|c|c|}
\hline & User Costs (at 5 Hour Rate) & Facility Cost & Tooling Cost \\
\hline \multicolumn{4}{|l|}{ Production at: } \\
\hline $500 / \mathrm{MWh} / \mathrm{Yr} . \quad(\mathrm{Pb}=259 / 1 \mathrm{~b})$ & $\$ 50.67 / \mathrm{kWh}$ & $\$ 1,670,000$ & $\$ 3,000,000$ \\
\hline $1000 /$ MWh $/ Y r$ & $\$ 48.72 / \mathrm{kWh}$ & $\$ 2,500,000$ & $\$ 4,000,000$ \\
\hline $4000 / \mathrm{MWh} / \mathrm{Yr}$. & $\$ 47.72 / \mathrm{MWh}$ & $\$ 10,000,000$ & $\$ 16,000,000$ \\
\hline
\end{tabular}

Trucking to site

$\$ 2.10 / \mathrm{kWh}$

Price of Replacement Battery (a) $\$ 36.13 / \mathrm{kWh}$

\footnotetext{
(a) Replacement Price = Price of second battery less value or use of first battery materials and components. (1984 \$).
} 
TABLE C.33. Hellman (1977) Manufacturing Cost Estimates

\begin{tabular}{|c|c|}
\hline Discharge Rate & Price \\
\hline 3 Hour & $\$ 61$ per kWh \\
\hline 5 Hour & $\$ 51$ per kWh \\
\hline 10 Hour & $\$ 44$ per kwh \\
\hline
\end{tabular}

PNL Note: The median manufacturing cost estimate of $\$ 51 / \mathrm{kWh}$ $(1976$ \$) was inflated to $\$ 86 /$ kwh $(1984 \$)$. 
TABLE C.34. Bechtel (1982) Balance of System Installed Costs

Battery: Lead Acid (Ant imony)

Application: Shopping Center

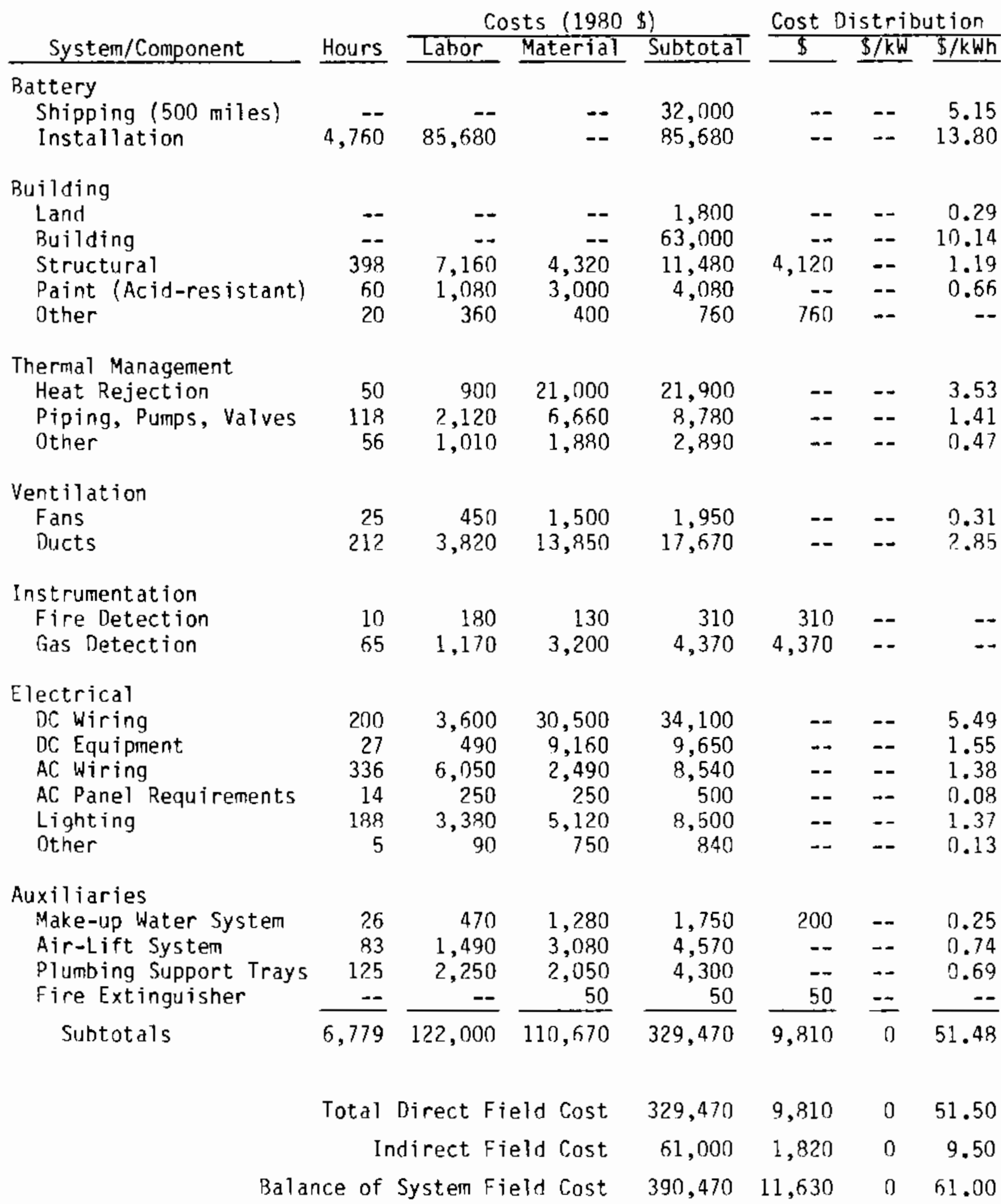


TABLE C.35. Rechtel (1982) Total Installed System Costs (1980\$)

Battery: Lead Acid (Antimony)

Application: Shopping Center

Low Estimate

\begin{tabular}{|c|c|c|c|c|c|c|c|c|}
\hline \multirow[b]{2}{*}{ Item } & & \\
\hline & Total Cost $\$$ & $\frac{\cos t}{\$}$ & $\begin{array}{l}\text { istrib } \\
\$ / \mathrm{kW} \\
\end{array}$ & $\begin{array}{l}\text { jtion } \\
\$ / \mathrm{kWh}\end{array}$ & Total Cost $\$$ & $\frac{\cos t}{\$}$ & $\frac{\text { istrib }}{\$ / \mathrm{kW}}$ & $\begin{array}{l}\text { ution } \\
\$ / \mathrm{kWh}\end{array}$ \\
\hline Battery, FOB & 533,910 & 0 & 0 & 86 & 821,400 & 0 & 0 & 132 \\
\hline 80 S, Field Cost (1) & 331,900 & 9,890 & $\underline{0}$ & 52 & 429,520 & 12,790 & $\underline{0}$ & 67 \\
\hline Total Field Cost & 865,810 & 9,980 & 0 & 138 & $1,250,920$ & 12,790 & 0 & 199 \\
\hline Engineering Costs (15\%) & 129,870 & 1,480 & $\underline{0}$ & 21 & 187,640 & 1,920 & $\underline{0}$ & 30 \\
\hline Subtotal & 995,680 & 11,370 & 0 & 159 & $1,438,560$ & 14,710 & 0 & 229 \\
\hline Contingency $(20 \%)$ & 199,140 & 2,270 & $\underline{0}$ & 32 & 287,710 & 2,940 & $\underline{0}$ & 46 \\
\hline Total Installed Cost & $1,194,820$ & 13,640 & 0 & 191 & $1,726,270$ & 17,650 & 0 & 275 \\
\hline
\end{tabular}

High Estimate

Note: From Table C.34. High $=1.1 \times$ Field Cost; Low $=0.85 \times$ Field Cost. 
TABLE C.36. Bechtel (1982) Frequent Maintenance for the Lead Acid Battery in the Shopping Center

\begin{tabular}{|c|c|c|c|c|c|}
\hline Activity & Frequency & $\begin{array}{c}\text { Labor, Manhours } \\
\text { per Event } \\
\end{array}$ & $\begin{array}{c}\text { Material, } \$ \\
\text { per Event }\end{array}$ & $\begin{array}{l}\text { Annual } \\
\text { Low } \$\end{array}$ & $\begin{array}{l}\text { Cost } \\
\text { High } \$\end{array}$ \\
\hline Cell Maintenance & Monthly & 11 & 74 & 2,340 & 2,808 \\
\hline Cooling System & Annual & 9 & 200 & 300 & 360 \\
\hline Ventilation System Exhaust Fan & Annual & 1 & -- & 11 & 13 \\
\hline Air Lift System Compressor & Annual & 4 & 50 & 94 & 113 \\
\hline
\end{tabular}


TABLE C.37. Bechtel (1982) Infrequent Maintenance for the Lead Acid Battery in the Shopping Center

\begin{tabular}{|c|c|c|c|c|c|}
\hline Activity & $\begin{array}{l}\text { Frequency, } \\
\text { Years } \\
\end{array}$ & $\begin{array}{c}\text { Labor, Manhours } \\
\text { per Event }\end{array}$ & $\begin{array}{l}\text { Material, \$ } \\
\text { per Event }\end{array}$ & $\begin{array}{l}\text { Event } \\
\text { Low } \$ \\
\end{array}$ & $\begin{array}{l}\text { Cost } \\
\text { High } \$\end{array}$ \\
\hline Cooling System Water Pump & 8 & 25 & 1,500 & 2,300 & 2,760 \\
\hline Refrigeration Systern & 12 & 30 & 9,000 & 9,960 & 11,950 \\
\hline Ventilation System Exhaust Fan & 8 & 10 & 200 & 520 & 624 \\
\hline Air Lift System Compressor & 6 & 30 & 2,000 & 2,960 & 3,552 \\
\hline
\end{tabular}


TABLE C.38. Bechtel (1982) Low Life-Cycle Cost Estimate (1980 \$)

Battery Type: Lead Acid (Antimony)

Application Type: Shopping Center

Low Estimate Input Parameters

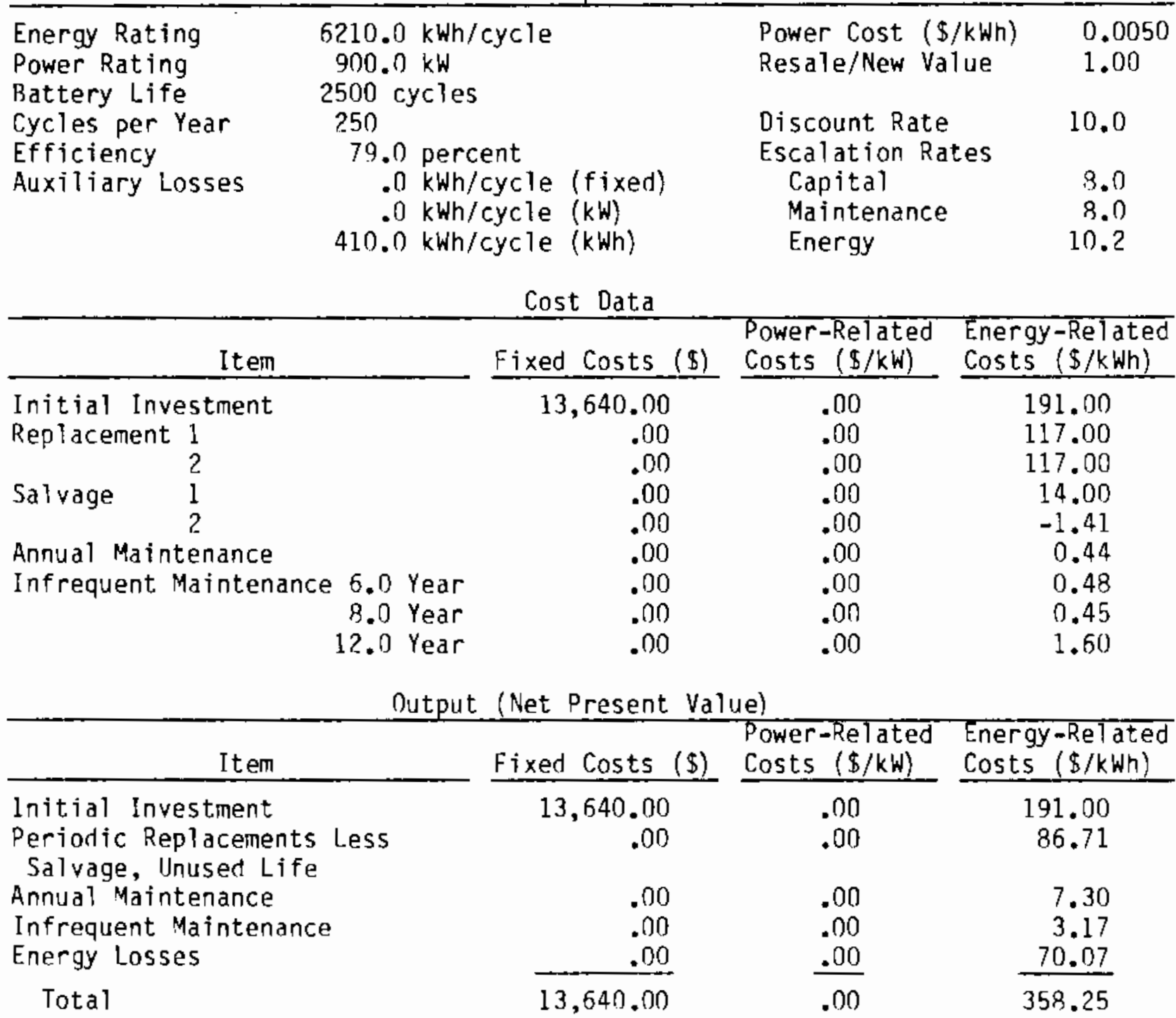

Total System Life-Cycle Cost: $\$ 2238$ thousand.

PNL Note: The life-cycle cost estimate of $\$ 358.25 / \mathrm{kWh}(1980 \$)$ was inflated to $\$ 447 / \mathrm{kWh}(1984 \$)$. 
TABLE C.39. Bechtel (1982) High Life-Cycle Cost Estimate (1980 \$)

Battery Type: Lead Acid (Antimony)

Application Type: Shopping Center

High Estimate Input Parameters

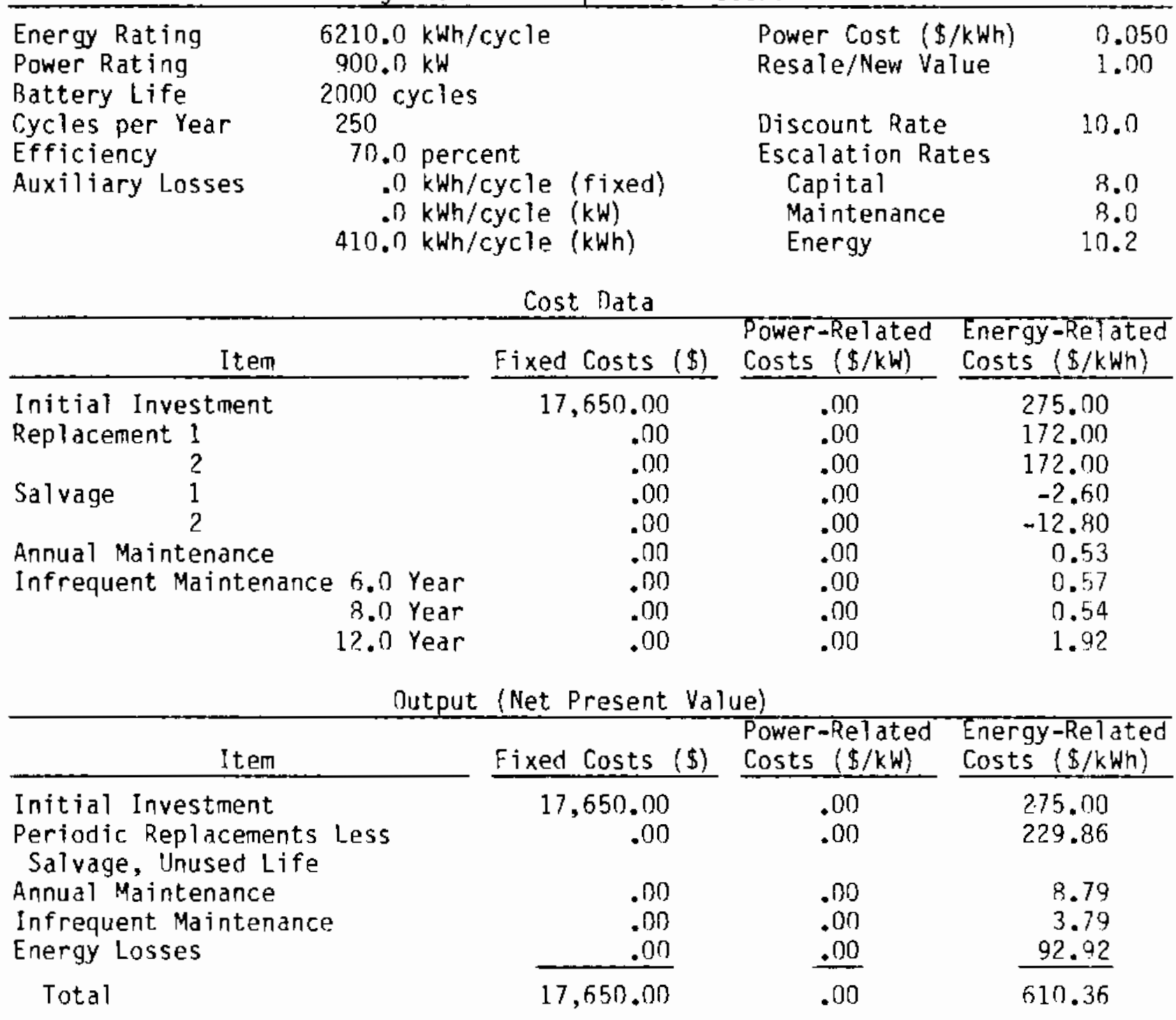

Total System Life-Cycle Cost: $\$ 3808$ thousand.

PNL Note: The life-cycle cost estimate of $\$ 610.35 / \mathrm{kWh}(1980 \$)$ was inflated to $\$ 761 / \mathrm{kWh}(1984 \$)$. 
TABLE C.40. Bechtel (1982) Balance of System Installed Costs

Battery: Sealed Lead Acid

Application: High School

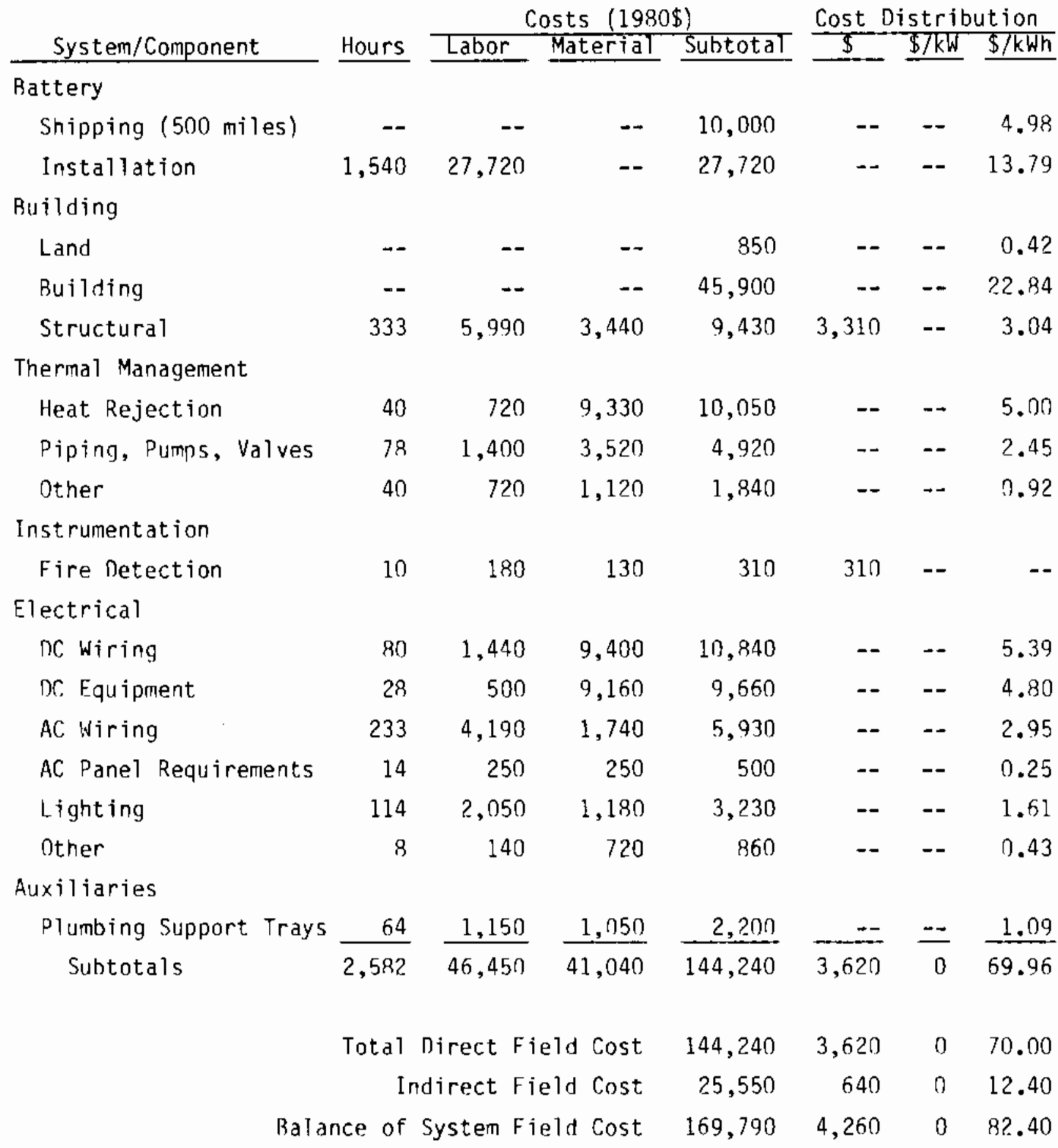


TABLE C.41. Bechtel (1982) Total Installed System Costs (1980\$)

Battery: Sealed Lead Acid

Application: High School

Low Estimate

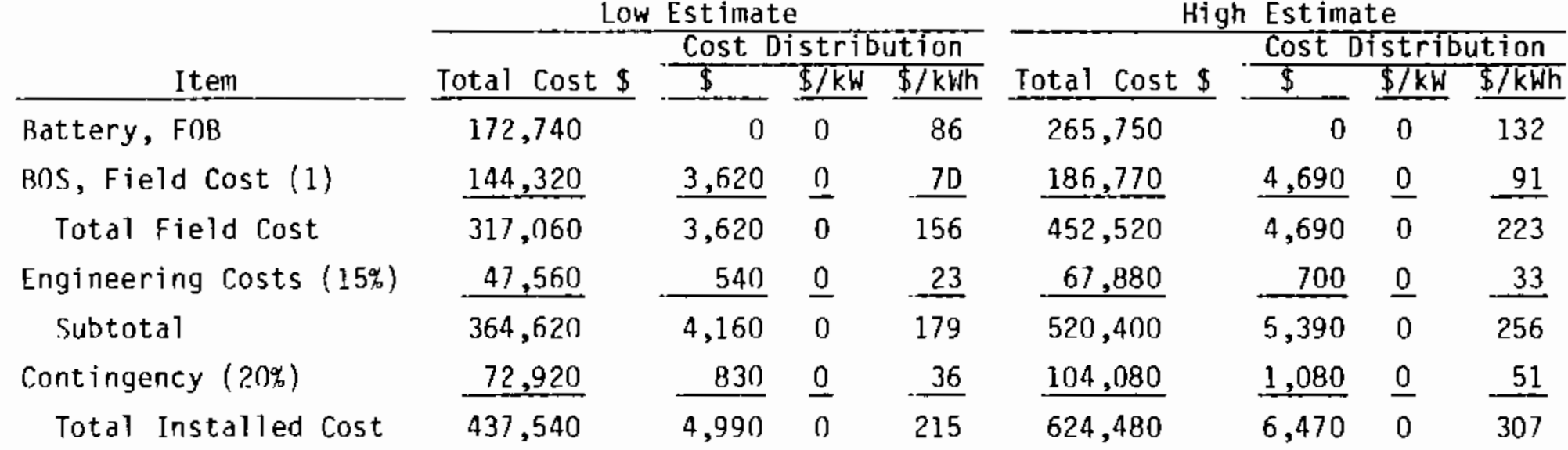

Note: From Table C.4n. High $=1.1 \times$ Field Cost; Low $=0.85 \times$ Field Cost. 
TABLF C.4?. Bechtel (1982) Frequent Maintenance for the Sealed Lead Acid Battery in the High School

\begin{tabular}{|c|c|c|c|c|c|}
\hline Activity & Frequency & $\begin{array}{c}\text { Labor, Manhours } \\
\text { per Event }\end{array}$ & $\begin{array}{l}\text { Material, } \$ \\
\text { per Event }\end{array}$ & $\begin{array}{l}\text { Annual } \\
\text { Low } \$ \\
\end{array}$ & $\begin{array}{l}\text { Cost } \\
\text { High } \$\end{array}$ \\
\hline Cell Maintenance & Annual & 1 & 0 & 11 & 13 \\
\hline Cooling Systern & Annual & $\gamma$ & 140 & 217 & 260 \\
\hline
\end{tabular}


TABLE C.43. Infrequent Maintenance for the Sealed Lead Acid Battery in the High School

\begin{tabular}{|c|c|c|c|c|c|}
\hline Activity & $\begin{array}{c}\text { Frequency, } \\
\text { Years }\end{array}$ & $\begin{array}{c}\text { Labor, Manhours } \\
\text { per Event } \\
\end{array}$ & $\begin{array}{l}\text { Material, } \$ \\
\text { per Event }\end{array}$ & $\begin{array}{l}\begin{array}{l}\text { Event } \\
\text { Low } \$\end{array} \\
\end{array}$ & $\begin{array}{l}\text { Cost } \\
\text { High } \$\end{array}$ \\
\hline Cooling System Water Pump & 8 & 25 & 1,180 & 1,980 & 2,376 \\
\hline Cooling System Refrigerator & 12 & 30 & 3,730 & 4,690 & 5,628 \\
\hline
\end{tabular}


TABLE C.44. Bechtel (1982) Low Life-Cycle Cost Estimate (1980 \$)

Battery Type: Sealed Lead Acid

Application Type: High School

Low Estimate Input Parameters

\begin{tabular}{lclc}
\hline Energy Rating & $2010.0 \mathrm{kWh} /$ cycle & Power Cost $(\$ / \mathrm{kWh})$ & 0.050 \\
Power Rating & $315.0 \mathrm{~kW}$ & Resale $/$ New Value & 1.00 \\
Battery Life & $2500 \mathrm{cycles}$ & & \\
Cycles per Year & 250 & Discount Rate & 10.0 \\
Efficiency & $79.0 \mathrm{percent}$ & Escalation Rates & \\
Auxiliary Losses & $.0 \mathrm{kWh} / \mathrm{cycle} \mathrm{(fixed)}$ & Capital & 8.0 \\
& $.0 \mathrm{kWh} /$ cycle $(\mathrm{kW})$ & Maintenance & 8.0 \\
& $176.0 \mathrm{kWh} /$ cycle $(\mathrm{kWh})$ & Energy & 10.2
\end{tabular}

Cost Data

\begin{tabular}{|c|c|c|c|}
\hline Item & Fixed Costs (\$) & $\begin{array}{l}\text { Power-Related } \\
\text { Costs }(\$ / \mathrm{kW})\end{array}$ & $\begin{array}{l}\text { Energy-Related } \\
\text { Costs }(\$ / \mathrm{kWh})\end{array}$ \\
\hline Initial Investment & $4,990.00$ & .00 & 215.00 \\
\hline Replacement 1 & .00 & .00 & 117.00 \\
\hline 2 & .00 & .00 & 117.00 \\
\hline Salvage & .00 &. $\mathrm{DO}$ & 14.00 \\
\hline ? & .00 & .00 & -1.39 \\
\hline Annual Maintenance & .00 & .00 & 0.11 \\
\hline Infrequent Maintenance 8.0 Year & .00 & .00 & 0.99 \\
\hline 12.0 Year & .00 & .00 & 2.33 \\
\hline
\end{tabular}

Output (Net Present Value)

\begin{tabular}{|c|c|c|c|}
\hline Item & Fixed Costs (\$) & $\begin{array}{l}\text { Power-Related } \\
\text { Costs }(\$ / \mathrm{kW}) \\
\end{array}$ & $\begin{array}{l}\text { Energy-Related } \\
\text { Costs }(\$ / \mathrm{kWh})\end{array}$ \\
\hline $\begin{array}{l}\text { Initial Investment } \\
\text { Periodic Replacements Less } \\
\text { Salvage, Unused Life }\end{array}$ & $\begin{array}{r}4,990.00 \\
.00\end{array}$ & $\begin{array}{l}.00 \\
.00\end{array}$ & $\begin{array}{r}215.00 \\
86.53\end{array}$ \\
\hline Annual Maintenance & .00 & .00 & 1.82 \\
\hline Infrequent Maintenance & .00 & .00 & 3.46 \\
\hline Energy Losses & .00 & .00 & 75.54 \\
\hline Total & $4,990.00$ & . 00 & 382.35 \\
\hline
\end{tabular}

Total System Life-Cycle Cost: $\$ 774$ thousand.

PNL Note: The life-cycle cost estimate of $\$ 382.35 / \mathrm{kWh}(1980 \$)$ was inflated to $\$ 477 / \mathrm{kWh}$ (1984\$). 
IABLE C.45. Bechtel (1982) High Life-Cycle Cost Estimate (1980 \$)

Battery Type: Sealed Lead Acid

Application Type: High School

High Estimate Input Parameters

\begin{tabular}{lcll}
\hline Energy Rating & $2010.0 \mathrm{kWh} /$ cycle & Power Cost $(\$ / \mathrm{kWh})$ & 0.050 \\
Power Rating & $315.0 \mathrm{~kW}$ & Resale/New Value & 1.00 \\
Battery Life & 2000 cycles & & \\
Cycles per Year & 250 & Discount Rate & 10.0 \\
Efficiency & 70.0 percent & Escalation Rates & \\
Auxiliary Losses & $.0 \mathrm{kWh} / \mathrm{cycle} \mathrm{(fixed)}$ & Capital & 8.0 \\
& $.0 \mathrm{kWh} / \mathrm{cycle}(\mathrm{kW})$ & Maintenance & 8.0 \\
& $176.0 \mathrm{kWh} / \mathrm{cycle}(\mathrm{kWh})$ & Energy & 10.2
\end{tabular}

Cost Data

\begin{tabular}{|c|c|c|c|}
\hline Item & Fixed Costs (\$) & $\begin{array}{l}\text { Power-Related } \\
\text { Costs }(\$ / \mathrm{kW}) \\
\end{array}$ & $\begin{array}{l}\text { Energy-Related } \\
\text { Costs }(\$ / \mathrm{kWh}) \\
\end{array}$ \\
\hline $\begin{array}{l}\text { Initial Investment } \\
\text { Replacement } 1 \\
\text { Salvage } \quad 1 \\
\text { Annual Maintenance } \\
\text { Infrequent Maintenance } 8.0 \text { Year } \\
\quad 12.0 \text { Year }\end{array}$ & $\begin{array}{r}6,470.00 \\
.00 \\
.00 \\
.00 \\
.00 \\
.00 \\
.00 \\
.00\end{array}$ & $\begin{array}{l}.00 \\
.00 \\
.00 \\
.00 \\
.00 \\
.00 \\
.00 \\
.00\end{array}$ & $\begin{array}{r}307.00 \\
172.00 \\
172.00 \\
-2.39 \\
-12.80 \\
0.14 \\
1.18 \\
2.80\end{array}$ \\
\hline \multicolumn{4}{|c|}{ Dutput (Net Present Value) } \\
\hline Item & Fixed Costs (\$) & $\begin{array}{l}\text { Power-Related } \\
\text { Costs }(\$ / \mathrm{kW})\end{array}$ & $\begin{array}{l}\text { Energy-Related } \\
\text { Costs (\$/kWh) }\end{array}$ \\
\hline $\begin{array}{l}\text { Initial Investment } \\
\text { Periodic Replacements Less } \\
\text { Salvage, Unused Life } \\
\text { Annual Maintenance } \\
\text { Infrequent Maintenance } \\
\text { Energy Losses } \\
\text { Total }\end{array}$ & $\begin{array}{r}.00 \\
.00 \\
.00 \\
6,470.00\end{array}$ & $\begin{array}{l}.00 \\
.00 \\
.00 \\
.00\end{array}$ & $\begin{array}{r}307.00 \\
229.61 \\
2.32 \\
4.15 \\
98.38 \\
641.46\end{array}$ \\
\hline
\end{tabular}

Total System Life-Cycle Cost: \$1296 thousand.

PNL Note: The 1ife-cycle cost estimate of $\$ 641.46 / \mathrm{kWh}(1980 \$$ ) was inflated to $\$ 800 / \mathrm{kWh}(1984 \$)$. 
TABLE C.46. Stolte (1977) Cost Estimate Summary Three Hour Lead Acid Battery Systems Mature Plants

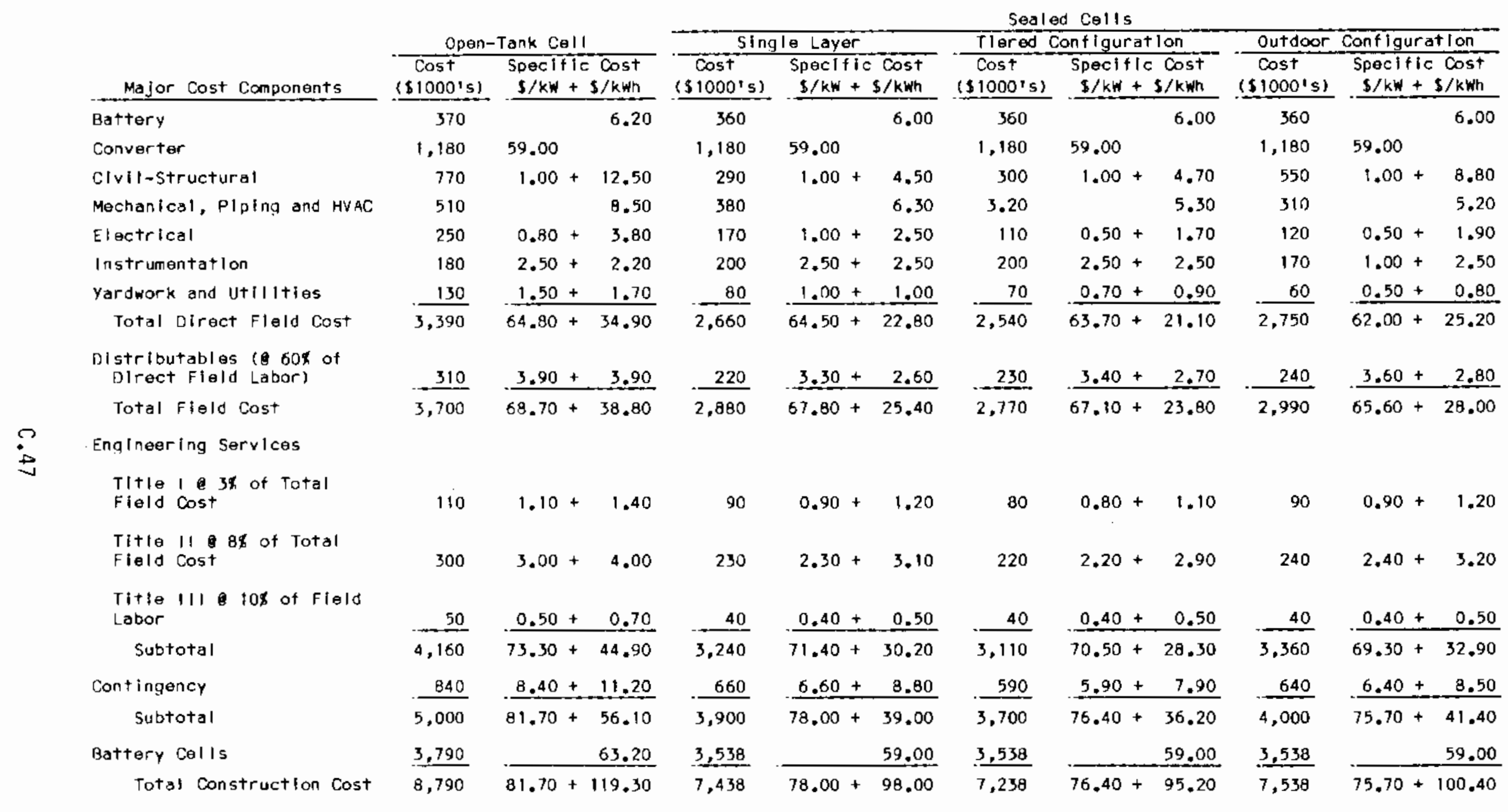

PNL Notes: Totat power-related balance of plant costs ranglng from $\$ 75.70$ to $\$ 82.80 / \mathrm{kW}(1976 \$$ ) in Tables C-46 and C-47 were $1 \mathrm{n} f \mathrm{lated}$ to $\$ 127$ to $\$ 139 / \mathrm{kW}(1984 \$)$.

Total energy-relsted balance of plant costs ranging from $\$ 28.00$ to $\$ 56.10 / \mathrm{kwh}$ (1976 \$) In Tables C-46 and C-47 were

inflated to $\$ 47$ to $\$ 94 / \mathrm{k}$ wh $(1984 \$)$. 


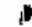


Sealed Cells

Open-Tank Cell $\frac{\text { Air-Cooled }}{\text { Cost Specific Cost }} \frac{\text { Water-Cooled }}{\text { Cost Specific Cost }}$

Major Cost Components

Battery

Converter

Civil-structural

Mechanical, Piping

and HVAC

Electrical

Ins trumentation

Yardwork and

Utilities

Total Direct

Field Cost

Distributables (a $60 \%$

of Direct Field

Labor)

Total Field cost

Engineering Services

Titie I d $3 \%$ of

Total Field cost

Title II $8 \%$ of

Total Field cost

Title III $10 \%$ of

Field Labor

Subtotal

Contingency

Subtotal

8attery Cells

Total Construc-

tion Cost

\section{$\left(\$ 1000^{\prime} \mathrm{s}\right) \$ / \mathrm{kW}+\$ / \mathrm{kWh}\left(\$ 1000^{\prime} \mathrm{s}\right) \$ / \mathrm{kW}+\$ / \mathrm{kWh}$}

$460 \frac{\$ / k H+S / k W h}{4.60} \frac{(S 1000 \mathrm{~s})}{600} \frac{\$ / k W+\$ / k W h}{6.00}$

$\begin{array}{rr}1,180 & 59.00 \\ 820 & 1.00\end{array}$

$1.00+8.00$

1,180

59.00

$\begin{array}{rrrr}490 & 4.90 & 610 & 6.10\end{array}$

$280-1.50+2.50$

$190 \quad 2.50+1.40$

290

$1.50+2.60$

$150 \quad 1.50+1.20$

130

$2.50+1.40$

$3,570 \quad 65.50+22.60 \quad 3,620 \quad 65.00+23.20$

3,920

$\frac{3.50+2.80}{69.00+25.40} \quad \frac{300}{3.920} \quad \frac{3.00+2.40}{68.00+25.60}$

, 920

$9.00+25.40$

120

120

$1.20+1.00$

$\frac{60}{4.410} \quad \frac{0.60+0.50}{73.90+29.30}$

$\frac{50}{4.400} \quad 0.50+0.40$

$\frac{890}{5,300} \quad \frac{8.90+7.10}{82.80+36.40} \quad \frac{900}{5,300}$

$9.00+7.20$

10,420

$\lcm{51.20} \quad 5,120$

51.20
Single Layer $\frac{\text { Tiered Configuration }}{\text { Cost }}$

$\frac{\left(\$ 1000^{\prime} \mathrm{s}\right)}{520} \$ / \mathrm{kW}+\$ / \mathrm{kWh}$

1,190

59.50

5.20

\begin{tabular}{cc} 
Cost & $\begin{array}{l}\text { Specific Cost } \\
\left.\$ 1000^{\prime} \mathrm{s}\right)\end{array} \$ \mathrm{~kW}+\$ / \mathrm{kWh}$ \\
\hline
\end{tabular}

Outdoor Configuration
Single Layer
Cost Specific cost

$520 \frac{5.20}{5.50}$

520

$1,190 \quad 59.50$

$1.00+3.80$

440

$1.00+4.20$

1,190

5.20

$\frac{\$ 1000 ' s)}{560}$

$\$ / \mathrm{kW}+\$ / \mathrm{kWh}$

$450-4.50-380$

$1.50+2.90$

$380-3.80$

750

1,190

59.50

250

$2.40+2.00$

240

$1.00+1.10$

390

1,060

$1.00+10.40$

3,160

$1.50+1.00$

$65.90+18.40$

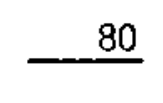

210

3.90

$1.00+1.10$

$1.00+1.90$

380

$2.50+1.90 \quad 210$

$1.00+0.60$

$\frac{60}{3,250}$

$0.50+\quad 0.50$

210

$1.50+0.90$

300

$380+2.20$

2,980

$65.00+16.80$

$63.00+19.90$

$\frac{40}{3,560}$

$0.50+0.30$

$63.50+22.90$

100

$1.00+0.80$

100

$1.00+0.80$

100

280

$2.80+2.20$

260

$2.60+2.10$

280

$\frac{50}{3.890}$

$\underline{0.50+0.40}$

$\frac{50}{3,690}$

$0.50+0.40$

50

$\frac{810}{4,700}$

$\frac{710}{4,400}$

5,406

54.10

5,406

$\frac{7.20+5.70+28.00}{4,800}$

$54.10 \quad 5,406$

$82.10+84.70 \quad 9,806 \quad 80.20+82.10 \quad 10,206$

$\frac{3.80+2.20}{66.80+22.10} \quad \frac{350}{3,910} \quad \frac{3.50+2.80}{67.00+25.70}$

$.80+87.60 \quad 10,420 \quad 81.80+87.80 \quad 10,106$

79


TABLE C.48. Westinghouse (1976) Battery Auxiliaries Costs

Building and $S 1 a b$

\begin{tabular}{lr}
$23,100 \mathrm{ft}^{2}$ at $\$ 15.15 / \mathrm{ft}^{2}$ & \\
Monitoring and Control & \\
\hline Computer with input/output & 175,000 \\
Computer startup and software & 20,000 \\
Isolation & 86,000 \\
Cabling & 67,000 \\
Input Devices & 16,000 \\
Static Contactors & 78,000
\end{tabular}

$\frac{\text { Total }}{\$ 350,000} \frac{\$ / \mathrm{kWh}}{8.75}$

Ventilation System

442,000

11.05

Ductwork

24,500

Fans and Stack

23,500

Acid Containment

110,000

2.75

Concrete Work

100,000

Excavation and Backfill

10,000

Buswork and Protection

81,500

2.04

Intermodule Cabling

11,500

Main Buswork

40,000

Fuse Disconnects

String Disconnects

23,000

7,000

Water Cooling

Cooling Tower

Piping

Pumps, Miscellaneous

48,000

1.20

Deionized Loop

54,500

47,500

5,000

10,000

Maintenance

49,000

1.23

Room and Equipment

34,000

Gantry

15,000

Fire System

$$
23,100 \mathrm{ft}^{2} \text { at } \sim \$ 1.08 / \mathrm{ft}^{2}
$$

$25,000 \quad 0.63$


TABLE C.48. Westinghouse (1976) Battery Auxiliaries Costs (contd)

$\frac{\text { Water Addition }}{\text { Demineralizer and Controls }}$
Piping
Reservoirs and Hookups
Auxiliaries Total
Battery Costs
Power Conversion (Estimated)
System Total

$\frac{\text { Total }}{33,000}$

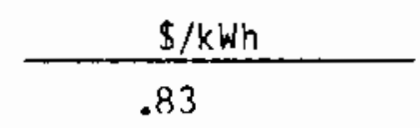

$$
\begin{array}{r}
5,000 \\
22,000 \\
6,000
\end{array}
$$$$
\$ 1,255,500
$$$$
31.39
$$$$
1,476,000
$$$$
36.90
$$$$
\frac{780,000}{\$ 3,511,500}
$$

$\frac{(\$ 78.00 / \mathrm{kW})}{+\$ 68.29 / \mathrm{kWh}}$
$+\$ 78.00 / \mathrm{kW}$

$(\$ 351.15 / \mathrm{kW}$ Total)

PNL Notes: The auxiliaries cost of $\$ 31.39 / \mathrm{kWh}(1976 \$$ ) was inflated to $\$ 53 / \mathrm{kWh}$ (1984 \$).

The power conversion cost of $\$ 78 / \mathrm{kW}(1976 \$)$ was inflated to $\$ 131 / \mathrm{kW}(1984 \$)$. 
APPENDIX D

PIRLICATIONS REVIEWED 


\section{APPENDIX D}

PUBLICATIONS REVIEWED

1. Bast, J. 1982. Development of Advanced Batteries for Utility Application. EPRI-EM-2579. By General Electric, Schenectady, New York, for Electric Power Research Institute, Palo Alto, California.

2. Bechtel Group, Inc. 1982. Study of Installed and Life-Cycle Costs for Batteries in Photovoltaic Power Systems. Final Report. SAND-82-7059. By Bechtel Group Inc., San Francisco, California, for Sandia National Laboratories, Albuquerque, New Mexico.

3. Bechtel Group, Inc. 1984. Economic Analysis of Specific CustomerSide-of-the-Meter Applications for Battery Energy Storage. San Francisco, California.

4. Bellows, R. J., et al. 1980. "Development of a Bipolar $\mathrm{ZnBr}$, Battery". In Proceedings, 15th Intersociety Energy Conversion Engineering Conference, Seattle, Washington.

5. Rellows, R. J., et al. 1983a. Development of a Circulating Zinc-Bromine Battery. Phase I. Final Report. SAND-82-7022. By Exxon Research and Engineering Co., Linden, New Jersey, for Sandia National Laboratories, Albuquerque, New Mexico.

6. Bellows, R. J., et al. 1983. "Zinc-Bromine Batteries for Bulk Energy Storage". In Proceedings, 17th Intersociety Energy Conversion Engineering Conference, OrTando, Florida.

7. Rellows, R. J., et al. 1983b. Development of a Circulating Zinc-Bromine Battery, Phase II. Final Report. SAND-83-7108. By Exxon Research and Engineering Co., Linden, New Jersey, for Sandia National Laboratories, Albuquerque, New Mexico.

8. Birk, J.R. 1977. "The Lead Acid Battery for Electric Utilities. A Review and Analysis." In Lead Acid Batteries for Utility Application Norkshop II. EPRI-EM-399-SR. Electric Power Research Institute, Palo Alto, California.

9. Boden, D. P. 1977. "A New Lead Acid Battery for Utility Peaking." In Lead Acid Batteries for Utility Application Workshop II. EPR!-EM399-SR. Electric Power Research institute, Pato Alto, California.

10. Brogan, J., and A. Landgrebe. 1984. "Battery Research: The Need and Status." In DOE/EPRI Beta (Sodium-Sulfur) Battery Workshop V. EPRI-EM-3631-SR. Electric Power Research Institute, Palo ATto, Cal ifornia. 
11. Bush, D. M., J. D. Sealey, and D. W. Miller. 1984. Testing of Sealed Lead Acid Batteries. SAND-83-2334. Sandia National Laboratory, ATbuquerque, New Mexico.

12. Ceramatec, Inc. 1980. Stationary Energy Storage and Electric Vehicle Cost Study - Manufacture of Beta"-Alumina Electrolytes, Alpha Alumina Head Sealers, and Sealing Operations. Ceramatec, Inc., Salt Lake city, Utah.

13. Clark, R. P., J. L. Chamberlin, K. R. Grothaus and K. D. Murphy. 1984. "Prospects for Advanced Storage Battery Technologies." In Proceedings, International Telecommunications Conference, New Orleans, Lousiana.

14. Das, R., H. Frank and S. Krauthamer. 1982. "Application of Electrochemical Energy Storage in Solar Thermal Electric Generation Systems". In Proceedings, Intersociety Energy Conversion Engineering Conference, Los Angeles, California.

15. DelMonaco, J. L., P. A. Lewis, H. T. Rowan, and J. Zemkoski. 1982. "Advanced Batteries for Load-Leveling: The Utility Perspective on System Integration." In IEEF Transactions on Power Apparatus and Systems. CONF-820134. Puhtic Service Electric and Gas Company, Newark, New Jersey.

16. Einstein, H., et al. 1981. Design and Cost Analysis of a $20 \mathrm{kWh}$ Bipolar Zinc-Bromine Battery. Exxon Research and Engineering Co., Linden, New Jersey.

17. Ferre11, D. T. 1977. "Lead Acid Load-Leveling Ratteries: The ESB Tubular Concept." In Lead Acid Batteries for Utility Application Workshop II. EPRI-EM-399-SR. Electric Power Research Institute, Palo Alto, California.

18. Ferre11, D. T., et a1. 1977. "Design and Cost Study for State of the Art Lead Acid Load Leveling and Peaking Batteries." EPRI-EM-375. Electric Power Research Institute, Palo Alto, California.

19. Ford Aerospace and Communication Corporation. 1980. Sodium Sulfur Battery Development: Economic Analys is; Phase IV Topical Status Report. DOE-CH-10n12-TT. Newport Beach, California.

20. Tates, A. R. 1983. "Status of the Ford Aerospace Sodium-Sulfur Battery Program." In Proceedings, 18th Intersociety Energy Conversion Engineering Conference, San Francisco, California.

21. George, J. H. R. 1979. Interim Cost Estimates for Advanced Battery Systems. EPRI-EM-742. A. D. Little, Inc., Cambridge, Massachusetts.

22. Hardy, K. S. 1985. Advanced Vehicle Systems Assessment. DOE-CS-54709-22. Jet Propulsion Lahoratory, Pasadena, Cal ifornia. 
23. Harlow, R. A. 1980. Sodium Sulfur Battery Development: Phase IV. Interim Report for March 1979-February 1979. D0E-CH-10D12-T2. Ford Aerospace and Communications Corp., Newport Beach, California.

24. Harlow, R. A. 1984. "An 0verview of the DOE/Ford Aerospace/Ford SodiumSulfur Battery Program." In Proceedings, EPRI Beta (Sodium Sulfur) Battery Workshop V. EPRI-EM-3631-SR. Electric Power Research Institute, Palo ATto, California.

25. Hellman, E. V. 1977. "Lead Acid Battery Design for Electric Utility Load Leveling." In Lead Acid Batteries for Utility Application Workshop II. EPRI-EM-399-SR. Electric Power Research Institute, Palo Alto, California.

26. Johnson, A. C., J. A. Hynds, D. R. Nevius, G. A. Nunan, and N. S. Weltnan. 1972. "Economic Assessment of the Utilization of Lead Acid Batteries in Electric Utility Systems." In Lead Acid Batteries for Utility Application Workshop 1I. EPRI-EM-399-Sr. Electric Power Research Institute, Palo Alto, California.

27. Krauthamer, S., and H. Frank. 1980. Electrochemical Energy Storage for Solar Thermal Applications. D0E/JPL-1060-38. Jet Propulsion Laboratory, Pasadena, California.

28. Kugler, G. G., and G. Martman. 1977. Cost and Design Study for Electric Vehicles Lead Acid Batteries. ANL-K-77-3621-1. Argonne National Laboratory, Chicago, Illinois.

29. Levine, C. A. 1981. Development of a Sodium SuTfur Battery Suitable for Use hy Electric Utilities and for Vehicular Propulsion.

DOETET/25103-T1. By The Dow Chemical Company, Walnut Creek, California, for the U.S. Department of Energy

30. Little, A. D. 1980. Commercialization Strategy for Lead/Acid Batteries in Utility Load Leveling Applications. D0E-ET-26934-1. By A. D. Little, Inc., Cambridge, Massachusetts, for the U.S. Department of Energy.

31. Long, A. H. 1977. "Study of the Manufacturing Costs of State-of-the-Art Lead Acid Batteries for Peaking Power." In Lead Acid Batteries for Utility Application Workshop II. EPRI-EM-399-SR. Electric Power Research Institute, Palo Alto, California.

32. Mahan, B. H. 1968. University Chemistry. Addison-Wesley Publishing, Inc., Reading, Massachusetts.

33. Monn, M. E. 1983. Design Study of $100 \mathrm{~kW}, 500 \mathrm{kWh}$ Zinc-Bromine Rattery System. Fluor Engineers and Constructors, Inc., and Energy Research Corporation, Irvine, California, for Electric Power Research Institiute, Palo Alto, California. 
34. Padder, A., and M. Kapner. 1981. Analysis of Batteries for Use in Photovoltaic Systems, Final Report. Hartman Associates, Inc., Columbia, Maryland.

35. Pittman, G. F. 1977. "Study of the Manufacturing Costs of Advanced Technology Lead Acid Batteries for Peaking Power". In Lead Acid Batteries for Utility Application Workshop II. EPRI-EM-399-SR. Electric Power Research Institute, Palo Alto, California.

36. Putt, R. A. 1979. Assessment of Technical and Economic Feasibility of Zinc/Bromine Batteries for Utility Load Leveling. Final Report. EPRI-EM-1059. By Gould, Inc., Rolling Meadows, Illinois, for Electric Power Research Institute, Palo Alto, California.

37. Putt, R., et al. 1980. Development of Zinc-Bromine Batteries for Utility Energy Storage, First Annual Report. D0E-ET-29345-21. Gould, Inc., Rolling Meadows, ITTinois.

38. Ramsay, G. B., and A. Edgecomb. 1982. Comparison of Prices for Conventional and Advanced Storage Batteries for Residential, Commercial, and Utility Applications. SAND-83-7050. By Gould, Inc., Rolling Meadows, Illinois, for Electric Power Research Institute, Palo Alto, California.

39. Roberts, R. 1984a. Development of Beta Batteries for Utility Application. EPRI-EM-3453. By General Electric Company, Schenectady, New York, for Electric Power Research Institute, Palo Alto, California.

40. Roberts, R. 1984b. "Overview of Beta Battery Development at General Electric and Chloride Silent Power Ltd." In Proceedings: DOE/EPRI Beta (Sodium-Sulfur) Battery Workshop V. EPRI-EM-3631-SR. ETectric Power Research Institute, Palo Alto, CaTifornia.

41. Sernka, R. P. 1984. "Reduction of Sodium-Sulfur Battery Development Costs" In Proceedings. DOE/EPRI Beta (Sodium-Sulfur) Battery Workshop $V$. EPRI-EM-3631-SR. Electric Power Research Institute, Palo Alto, California.

42. Shah, K. R., and F. S. Prabhakara. 1977. "Economic Assessment of $\mathrm{Pb}-\mathrm{H}_{2} \mathrm{SO}_{4}$ Batteries for Non-Generating Utilities and Large Industrial Customers." In Lead Acid Batteries for Utility Application Workshop II. EPRI-EM-399-SR. Electric Power Research Institute, Palo Alto, California.

43. Sholette, W. P. 1984. Testing, Data Analysis, and Engineering Services on Lead Acid Load Leveling Ratteries. SAND-84-7104. Sandia Kationat Laboratory, Albuquerque, New Mexico.

44. Simon, A. C., E. E. Wells, S. Caulder. March 1977. Prospects and Potential of Advanced Lead Acid Batteries." In Lead Acid Batteries for Utility Application Workshop II. EPRI-EM-399-SR. ETectric Power Research Institute, Palo Alto, California. 
45. Smith, J. C. 1977. "Summary Economic Comparisons." In Lead Acid Batteries for Utility Application Workshop II. EPRI-EM-399-SR. Electric Power Research Institute, Palo Alto, California.

46. Stolte, W. J. 1977. "An Engineering Study of a 20 MW Lead Acid Battery Energy Storage Demonstration Plant." In Lead Acid Ratteries for Utility Application Workshop II. EPRI-EM-399-SR. Electric Power Research Institute, PaTo Alto, California.

47. Stolte, W. J. 1982. Feasibitity Assessment of Customer-Side-of-the-Meter Applications for Battery Energy Storage. EPRI-EM-2769. By Bechtel Group, Inc., San Francisco, California, for ETectric Power Research Institute, Palo Alto, California.

48. Sudsworth, J. L. 1984. "Status of Beta Batteries 1983: A Review and Analysis of Workshop V Information" In Proceedings: DOE/EPRI Beta (Sodium-Sulfur) Battery Workshop V. EPRT-EM-3631-SR. Electric Power Research Institute, Palo ATto, CaTifornia.

49. Tow7e, W. L. 1977. "Lead Acid Cell of High Performance for Utility Network." In Lead Acid Batteries for Utility Application Workshop I I. EPRI-EM-399-SR, Electric Power Research Institute, Palo Alto, California.

50. U.S. Department of Energy. 1981. Ratteries for Energy Storage. DOE $/$ CS-0152.

51. Irry, L. F. 1983. "Batteries." In Van Nostrand's Scientific Encyclopedia. 6th ed. D. E. Considine and G. D. Considine 1983, Van Nostrand Reinhold Co., New York, New York.

52. Vai11, R. E. 1977. "Study of the Auxiliaries for Lead Acid Battery Systems for Peaking Power." In Lead Acid Batteries for Utility Application Workshop II. EPRI-EM-399-SR. Electric Power Research Institute, Palo A7to, California.

53. Weinlein, C. E. 1977. Design and Cost Study for Development of Lead Acid Batteries Suitahle for ETectric Vehicle Propulsion. ANL-K-77-3624-1. Argonne National Laboratory, Chicago, llitinois.

54. Weinstock, I. B. 1984. D0E Rattery Development Program: Hardware Performance Status in 1983. ATR-84(4821-04)-1WD. The Aerospace Corporation, Washington, D.C.

55. Westinghouse Electric Corporation. 1976. Study of the Auxilaries for Lead Acid Battery Systems for Peaking Power. ConS/2114-3. Westinghouse, Pittsburgh, Pennsynvania.

56. Wicker, A., and J. P. Pompon. 1981. Economic Assessment and Comparison of Alternative Beta-Alumina Electrolytes. EPR!-EM-1799. By Compagnie Generale D'Electricite, Marcoussis, France, for Electric Power Research Institute, Palo Alto, California. 
57. Wicker, A., and J. P. Pompon. 1979. Sodium-Sulfur Battery Supporting R\&D: An Evaluation of Alternative Electrolyte and Battery Price. EPRI EM-1116. By Compagnie Generale D'Electricite, Marcoussis, France, for Electric Power Research Institute, Palo Alto, California.

58. Wil1, F. G., C. C. Iacovangelo, J. S. Jackowski and F. W. Secor. 1978. Assessment of the Zinc-Bromine Battery for Utility Load Leveling, Final Report. COO-2450-1. GeneraTElectric Co., Schenectady, New York. 


\section{REFERENCES}

Bast, J. 1982. Development of Advanced Batteries for Utility Application. EPRI-EM-2579. By General Electric, Schenectady, New York, for Electric Power Research Institute, Palo Alto, California.

Bechtel Group, Inc. 1982. Study of Installed and Life-Cycle Costs for Batteries in Photovoltaic Power Systems. Final Report. SAND-82-7059. By Bechtel Group, Inc., San Francisco, for Sandia National Laboratories, Albuquerque, New Mexico.

Bellows, R. J., et al. 1983a. Development of a Circulating Zinc-Bromine Battery. Phase I. Final Report. SAND-82-7022. By Exxon Research and Engineering Co., Linden, New Jersey, for Sandia National Laboratories, Albuquerque, New Mexico.

Bellows, R. J., et al. 1983b. Development of a Circulating Zinc-Bromine Battery, Phase II. Final Report. SAND-83-7108. By Exxon Research and Engineering Co., Linden, New Jersey, for Sandia National Laboratories, Albuquerque, New Mexico.

Birk, J. R. 1977. "The Lead Acid Battery for Electric Utilities. A Review and Analysis." In Lead Acid 8atteries for Utility Application Workshop II. EPRI-EM-399-SR. Flectric Power Research Institute, Palo Alto, California.

Boden, D. P. 1977. "A New Lead Acid Battery for Vtility Peaking." In Lead Acid Ratteries for Utility Application Workshop II. EPRI-EM-399-SR. Electric Power Research Institute, Palo ATto, California.

Ceramatec, Inc. 1980. Stationary Energy Storage and Electric Vehicle Cost Study - Manufacture of Beta"-Alumina Electrolytes, Alpha Alumina Head Sealers, and Sealing Operations. Cerametec, Inc. Salt Lake City, Ittah.

Ferre11, D. T. 1977. "Lead Acid Load-Leveling Batteries: The ESB Tubular Concept". In Lead Acid Batteries for Utility Application Workshop II. EPRI-EM-399-SR. Electric Power Research Institute, Palo Alto, California.

Ferrell, D. T., et al. 1977. Design and Cost Study for State of the Art Lead Acid Load Leveling and Peaking Batteries. EPRI-EM-375. Electric Power Research Institute, Palo Alto, California.

Ford Aerospace and Communication Corporation. 1980. Sodium Sulfur Battery Development: Economic Analysis; Phase IV Topical Status Report. DOE-CH-10012-T1. By Ford Aeropsace and Comnunication Corporation, Newport Beach, California, for the U.S. Department of Energy.

George, J. H. R. 1979. Interim Cost Estimates for Advanced Battery Systems. EPRI-EM-742. By A. D. Littie, Inc., Cambridge, Massachusetts, for Electric Power Research Institute, Palo Alto, California. 
Harlow, R. A. 1984. "An Overview of the DOE/Ford Aerospace/Ford Sodium-Sulfur Battery Program". In Proceedings: EPRI Beta (Sodium-Sulfur) Battery Workshop V. EPRI-EM-3631-SR. Electric Power Research Institute, Palo Alto, California.

Hellman, E. V. 1977. "Lead Acid Battery Design for Electric Utility Load Leveling." In Lead Acid Batteries for Utility Application Workshop II. EPRI-EM-399-SR. Electric Power Research Institute, Palo Al to, California.

Levine, C. A. 1981. Development of a Sodium Sulfur Battery Suitable for Use by Electric Utilities and for Vehicular Propulsion. D0E/ET/25103-Tl. By The Dow Chemical Company, Walnut Creek, California, for the IJ.S. Department of Energy.

Long, A. H. 1977. "Study of the Manufacturing Costs of State-of-the-Art Lead Acid Batteries for Peaking Power". In Lead Acid Batteries for Utility Application Workshop II. FPRI-EM-399-SR. ETectric Power Research Institute, Palo Alto, California.

Monn, M. E. 1983. Design Study of $100 \mathrm{~kW}, 500 \mathrm{kWh}$ Zinc-Bromine Battery System. By Fluor Engineers and Constructors, Inc. and Energy Research Corporation, Irvine, California, for Electric Power Research Institute, Palo Alto, California.

Pittmann, G. F. 1977. "Study of the Manufacturing Costs of Advanced Technology Lead Acid Batteries for Peaking Power". In Lead Acid Batteries for Utility Application Workshop II. EPRI-EM-399-SR. Electric Power Research Institute, Palo Alto, CaTifornia.

Ramsay, G. B., and A. Edgecomb. 1982. Comparison of Prices for Conventional and Advanced Storage Batteries for Residential, Commercial and Utility Applications. SAND-83-7050. By Gould, Inc., Rolling Meadows, Illinois, for Sandia National Laboratories, Albuquerque, New Mexico.

Roberts, R. 1984. Development of Beta Batteries for Utility Application. EPRI-EM-3453. By General Electric Company, Schenectady New York for ETectric Power Resarch Institute, Palo Alto, California.

Sernka, R. P. 1984. "Reduction of Sodium-Sulfur Battery Development Costs". In Proceedings: DOE/EPRI Beta (Sodium-Sulfur) Battery Workshop $V$. EPRI-EM-3631-SR. Electric Power Research Institute, Palo ATto, California.

Stolte, W. J. 1977. "An Engineering Study of a $20 \mathrm{MW}$ Lead Acid Battery Energy Storage Demonstration Plant". In Lead Acid Batteries for Utility Applications Workshop II. EPRI-EM-399-SR. Electric Power Research Institute, Palo Alto, California. 
Stolte, W. J. 1982. Feasibility Assessment of Customer-Side-of-the-Meter Applications for Bat tery Energy Storage. EPRI-EM-2769. By Bechtel Group, Inc., San Francisco, California, for ETectric Power Research Institute, Palo Alto, California.

Towle, W. L. 1977. "Lead Acid Cell of High Performance for Utility Network." In Lead Acid Batteries for Utility Application Workshop II . EPRI-EM-399-SR. ETectric Power Research Institute, Palo ATto, California.

Vaill, R. E. 1977. "Study of the Auxiliaries for Lead Acid Battery Systems for Peaking Power". In Lead Acid Batteries for Itility Application Workshop II. EPRI-EM-399-SR. ETectric Power Research Institute, Palo Alto, California.

Weinlein, C. E. 1977. Design and Cost Study for Development of Lead Acid Batteries Suitable for Electric Vehicle Propulsion. ANL-K-77-3624-1. Argonne Nationat Laboratory, Chicago, Illinois.

Westinghouse Electric Corporation. 1976. Study of the Auxiliaries for Lead Acid Battery Systems for Peaking Power. CoNS/2114-3. Westinghouse, Pittsburgh, PennsyTvania.

Wicker, A., and J. P. Pompon. 1979. Sodium-Sulfur Battery Supporting R\&D: An Evaluation of Alternative Electrolyte and Battery Price. EPRI-EM-1116. By Compagnie Generale d'Electricite, Marcoussis, France, for Electric Power Research Institute, Palo Alto, California.

Wicker, A., and J. P. Pompon. 1981. Economic Assessment and Comparison of Alternative Beta-Alumina Electrolytes. EPRI-EM-1799. By Compagnie Generale d'Electricite, Marcoussis, France, for Electric Power Research Institute, Palo Alto, California. 
,

$i$

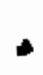


PNL-5741

JUC-94cb

DISTR IBUTION

No. of

Copies

OFFSITE

1n J. E. Quinn

U.S. Department of Energy

Forrestal Building

1000 Independence Avenue, SW

Washington, DC 20585

A. R. Landgrebe

IJ.S. Department of Energy

Forrestal Building

1000 Independence Avenue, SW

Washington, DC 20585

P. Patil

U.S. Department of Energy

Forrestal Building

1000 Independence Avenue, SW

Washington, DC 20585

K. W. Klien

U.S. Department of Energy

Forrestal Building

1000 Independence Avenue, SW

Washingt on, DC 20585

30 noE Technical Information

Center

W. J. Stolte

Bechtel Group, Inc.

Research and Engineering

Operation

50 Reale Street

Sar Francisco, CA 94119

Patrick frimes

Exxon Research and

Engineering $\mathrm{Co}$.

P. 0 . Box 45

Linden, NJ 07036
No. of

Copies

M. G. Monn

Fluor Engineers and

Constructors, Inc.

Advanced Technology Division

P.0. Box C-11944

Santa Ana, CA 92711

G. B. Ramsay

Gould Research Center

40 Gould Center

Rolling Meadows, IL 60008

G. Sands

Chloride Silent Power, Ltd.

Oavy Raod

Astmoor

Cheshire WA71PZ

England

A. Wicker

Compagnie Generale

D'Electricite

Laboratories de Marcoussis

Centre de Recherches

92460 Marcoussis, France

Robert W. Minck

Ford Aerospace and

Communications Corp.

Aeronautics Division

Ford Road

Newport Beach, CA 92663

P. E. Pierini

Dow Chemical Company

2800 Mitchell Drive

Walnut Creek, CA 94598

Robert Schainker

Electric Power Research

Institute

3412 Hillview Avenue

P.0. Box 10412

Palo Alto, CA 94303 
No. of

Copies

Kevin Murphy

Sandia National Laboratories

P.ก. Box 5800

Albuquerque, NM 87185

Tony Leo

Energy Research Corporation

3 Great Pasture Road

Danbury, CT 06810

John Del Monaco

Public Service Flectric \& Gas

Company

80 Park Plaza

Newark, NJ 07101

Jack Brown

Westinghouse Electric

Corporation

Research and Development Center

1310 Beulah Road

Pittsburgh, PA 15235

Thomas Ferrell

3871 Dempsy Lane

Huntington Valley, PA 19006

Conrad Weinlein

Johnson Controls, Inc.

Battery Division

5757 Green Bay Avenue

Milwaukee, WI 53201

David P. Boden

CRI Batteries

Plymouth Meeting, PA 19462
No. of

Copies

ONSITE

3 DOE - Richland Operations

D. R. Segna

D. K. Jones

J. J. Sutey

38

Pacific Northwest Laboratory

R. C.. Adams

W. B. Ashton

D. R. Brown (20)

J. W. Currie

L. L. Fassbender

B. J. Harrer

C. J. Hostick

J. W. Hurwitch

C. H. Imhoff

B. L. Mohler

J. A. Russell

R. K. Sen

Publishing Coordination (2) $\mathrm{MH}$

Technical Information (5) 